\title{
Electrical Utilities Model for Determining Electrical Distribution Capacity
}

Eectrical Utilities

DynCorp Tri-Cities Services, ho.

Dris Pustlithed

September 1997

Prepared for the U.S. Deportmert of Energy

Assistent Secretery for Emkronmertal Misnegernent

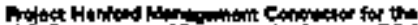

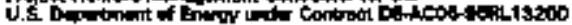

Approved for public release; distribution is unlimited 
HWF-SP-Iß36, REV, 0

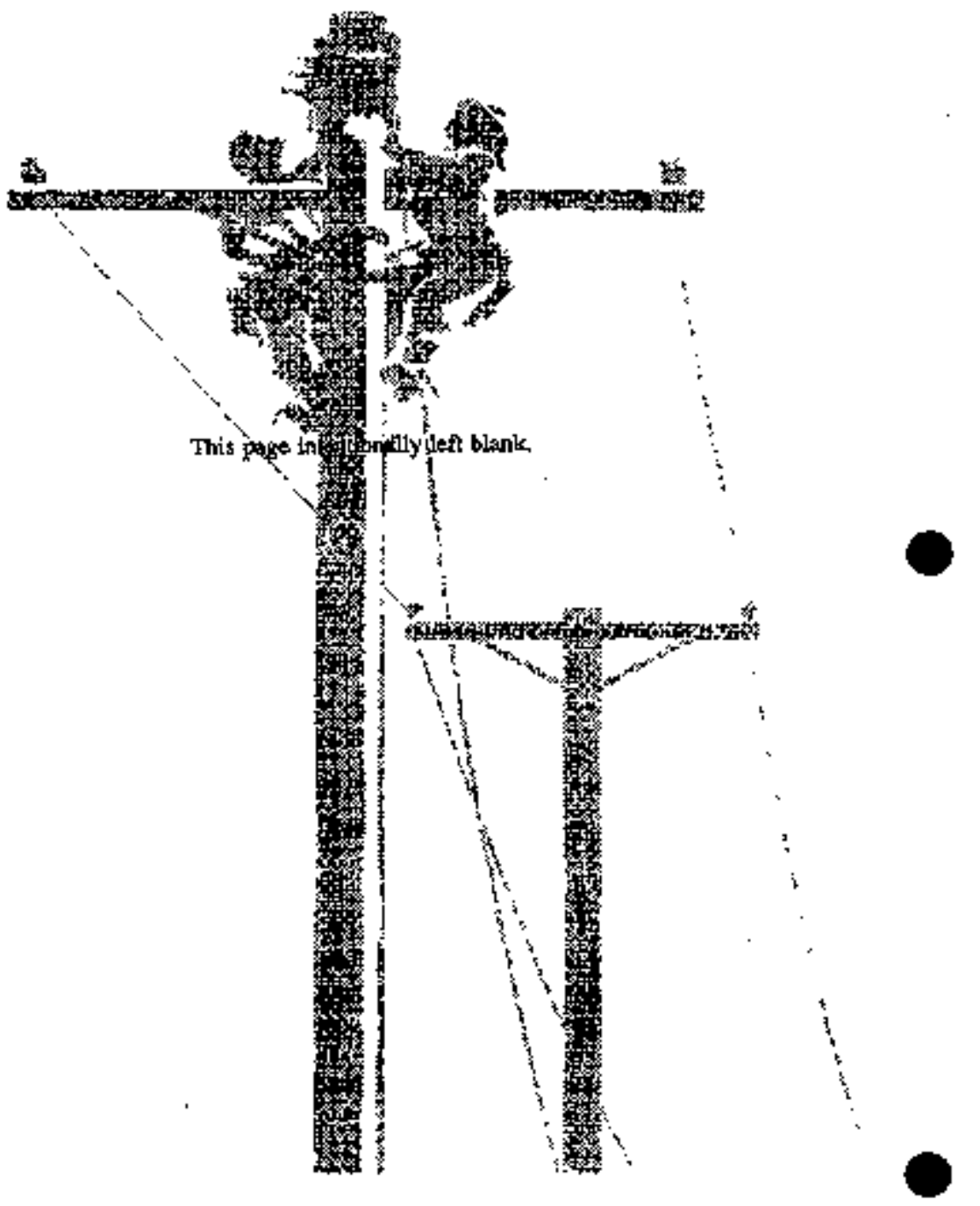




\section{RELEASE AUTHORIZATION}

Document Mumber: HafF-5P-1236

Document Thla: Electrical ttifities Nodel for Deterwining

Electrical 0tstribution Capacity

Aelease Date: $\quad \$ / 3 / 97$

This document was reviewed following the pxocedures described in WHC-CM-3-4 and is:

APPROVED FOR PUBAIC RELEASE

WHC information Rebaga Adrinițtration spackedequ:

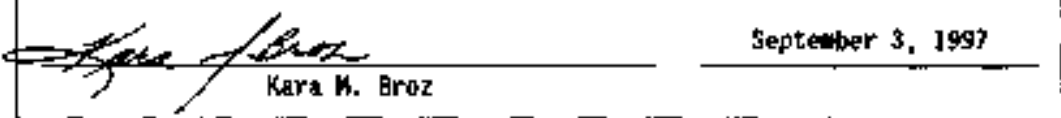


HNF-SP-1236, REV, O

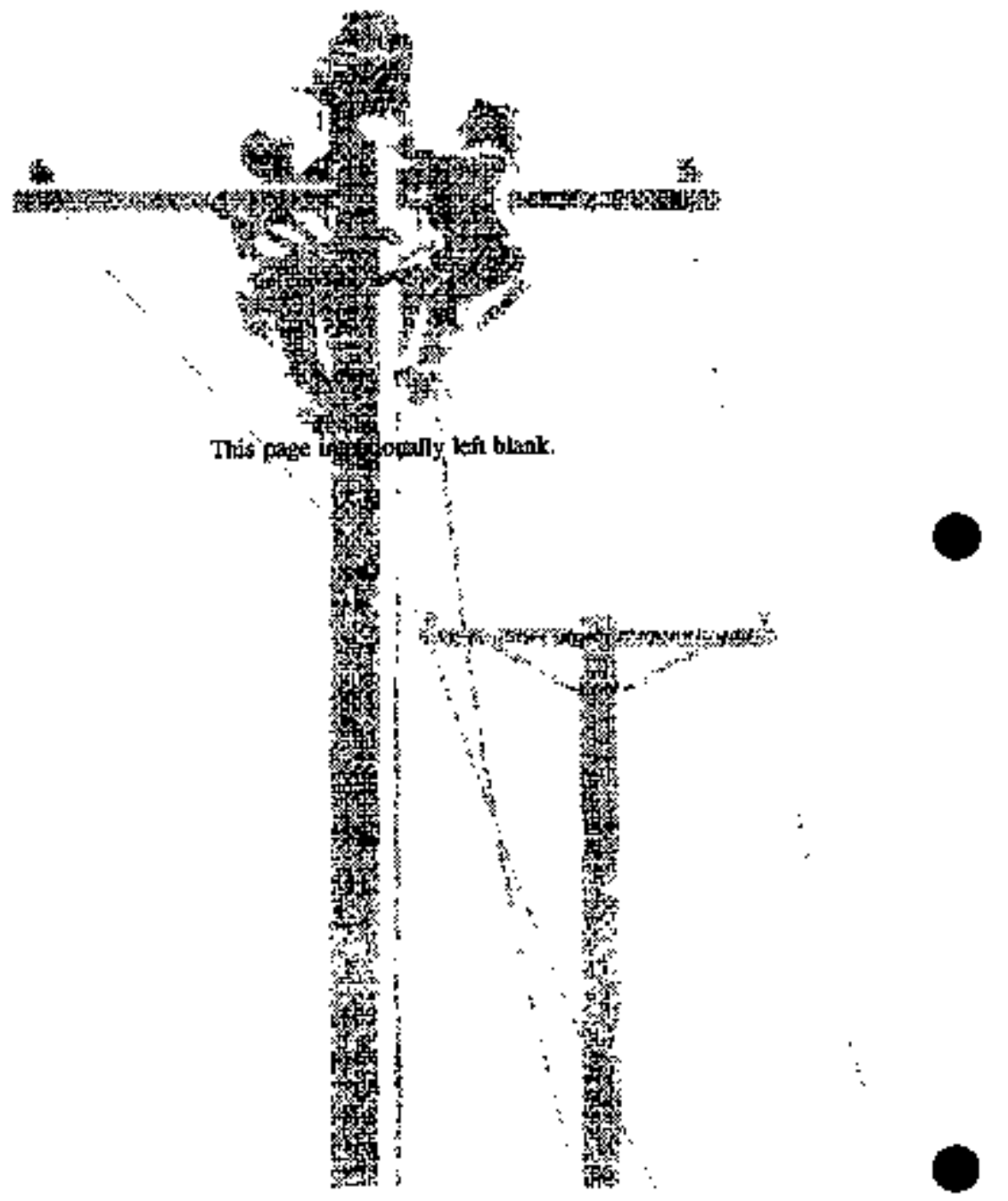




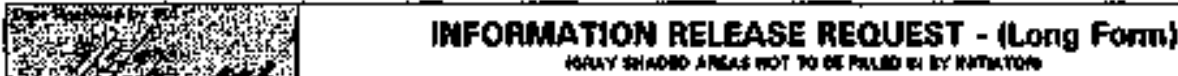

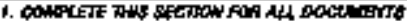

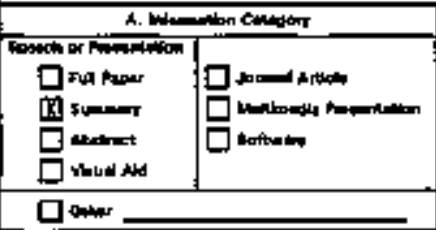

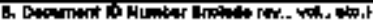

HNF-5P-1236

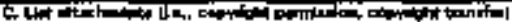
Nons:

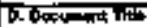

Electracal Utilithes Model for Oeterging Elactrical Distribution Capatity

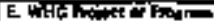
Drucorp Tri-Cities sorvites, Inc. Electrical Ut111ties

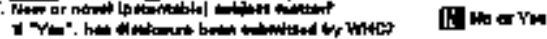

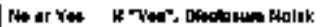

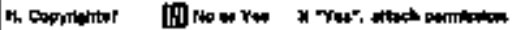

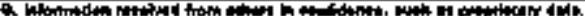

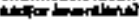

Ii Mr a Yan

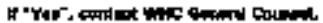

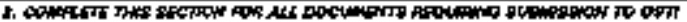

\begin{tabular}{|c|c|c|}
\hline A. Whelostifed Cungary & 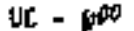 & 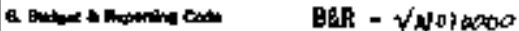 \\
\hline
\end{tabular}

1. Node af tewmel

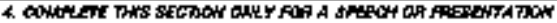

\begin{tabular}{|c|c|c|c|}
\hline 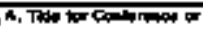 & Tritag & 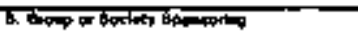 & \\
\hline 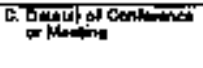 & B. Chention: & 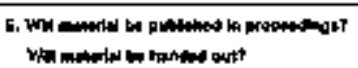 & $\begin{array}{l}\text { No pr ves } \\
\text { hop or res }\end{array}$ \\
\hline
\end{tabular}

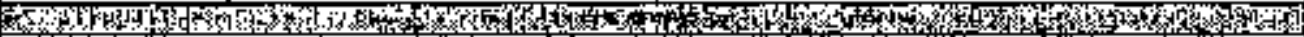

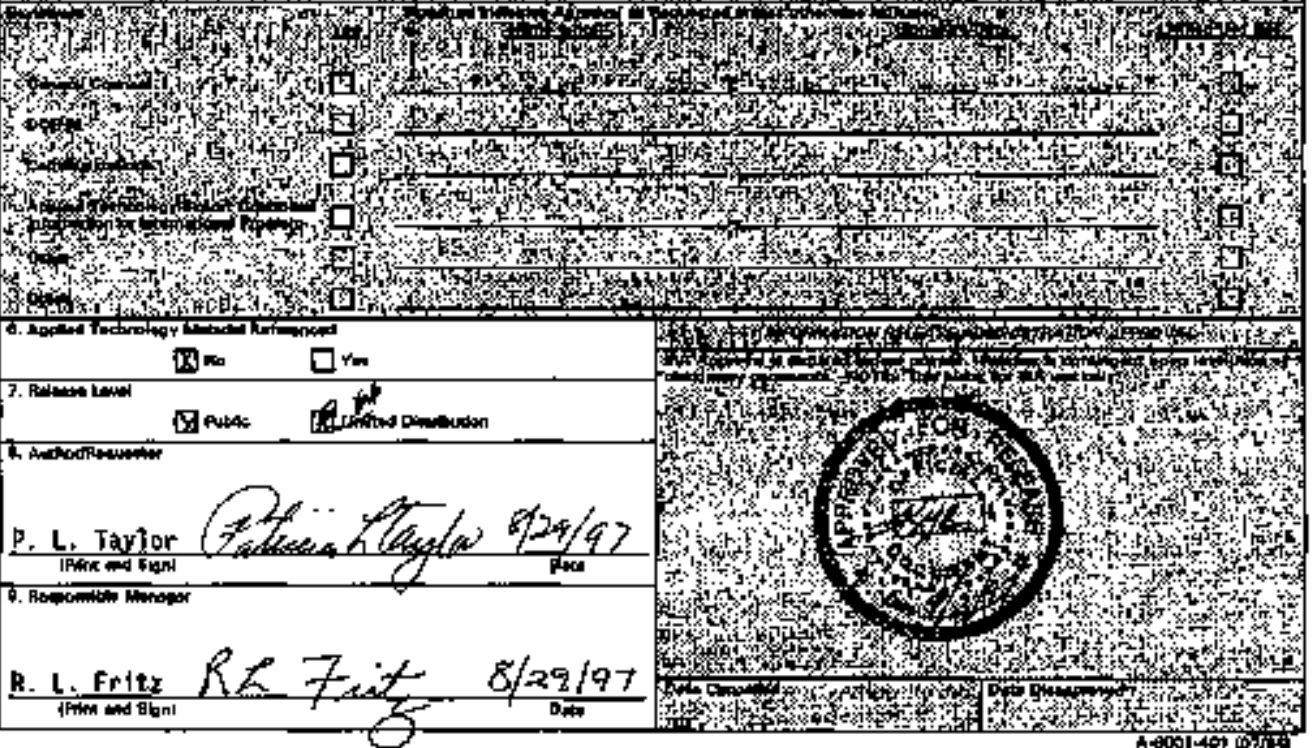




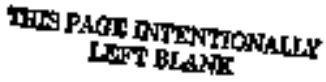


FEI PAOR INTERTTCNALLT

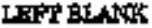


HNF-SP-123\%, REV , 0
EIIFCTRICAL UTLITIES MODEL FOR DETERMINING
ELECTRICAL DISTRIBUTION CAPACITY

1. EXECUTTVE SUMMaRY $\ldots \ldots \ldots \ldots \ldots \ldots \ldots \ldots \ldots \ldots$

1.1 Introduction $\ldots \ldots, \ldots, \ldots, \ldots, \ldots, \ldots, \ldots, \ldots, 1$

1.2 Proactive Reetemetring $\ldots \ldots \ldots \ldots \ldots \ldots \ldots \ldots \ldots$.

1.3 Recummendations $\ldots \ldots, \ldots \ldots \ldots \ldots, \ldots \ldots, 3$

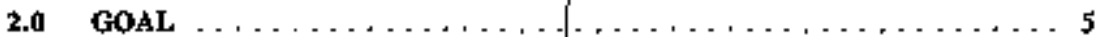

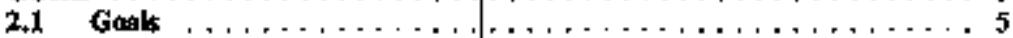

2.2 Objectlves and strategies $\ldots \ldots \ldots \ldots \ldots \ldots \ldots \ldots \ldots \ldots$ s

2.3 Pexfarmande Meatsurv $\ldots, \ldots, \ldots \ldots \ldots, \ldots, \ldots, 5$

3.0 REGULATORY REQUIREMIENTS $\ldots \ldots \ldots \ldots \ldots \ldots \ldots \ldots \ldots$

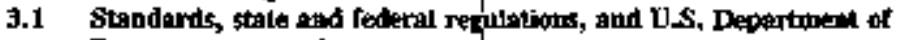

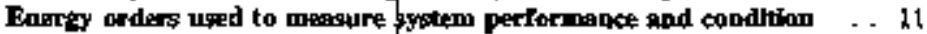

3.2 Marketing Opportnmities $\ldots \ldots \ldots \ldots \ldots \ldots \ldots \ldots \ldots$ 14

4.0 BASELINE OPERATIONS $\ldots \ldots \ldots \ldots \ldots \ldots \ldots \ldots \ldots$ is

4.1 Mission $\ldots \ldots \ldots \ldots \ldots \ldots \ldots \ldots \ldots \ldots \ldots, \ldots \ldots \ldots$

4.2 Worktorce Organization $\ldots \ldots \ldots \ldots \ldots \ldots \ldots \ldots \ldots, 15$

4.21 Operstipas $\ldots \ldots \ldots, \ldots \ldots \ldots \ldots \ldots \ldots, 15$

$4.2,2$ Adminingration $\ldots \ldots \ldots \ldots \ldots \ldots \ldots \ldots \ldots, 16$

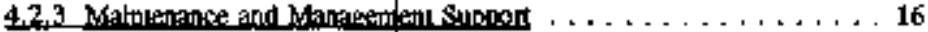

$4.2,4$ Support From Othert $\ldots \ldots \ldots \ldots \ldots \ldots \ldots \ldots \ldots, 17$

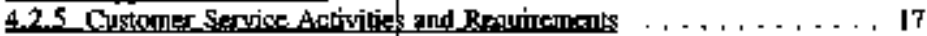

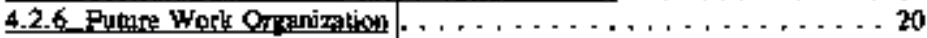

4.3 Economir transtition needs $\ldots \ldots \ldots \ldots \ldots \ldots \ldots \ldots \ldots, 21$

5.0 BASELINE TRANSMISSION AND DISTRIBUTJON SYSTEME $\ldots \ldots, 23$

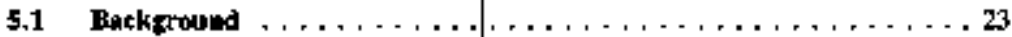

5.2100200 Ares system. $\ldots \ldots \ldots \ldots \ldots \ldots \ldots \ldots \ldots \ldots, 27$

5.2, Lepcrpption $\ldots \ldots \ldots \ldots \ldots \ldots \ldots \ldots \ldots \ldots, 27$

$5,2,2$ Assessment of Condition $\ldots \ldots \ldots \ldots \ldots, \ldots, \ldots, \ldots, 27$

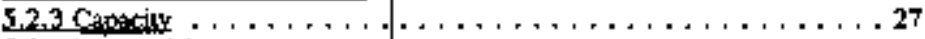

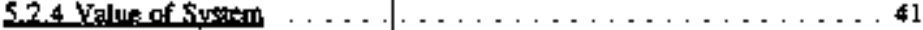

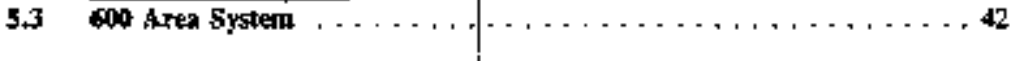




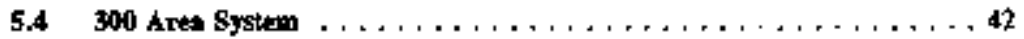

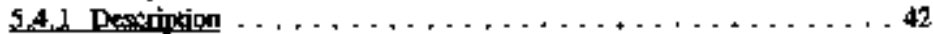

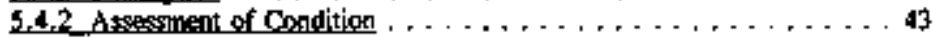

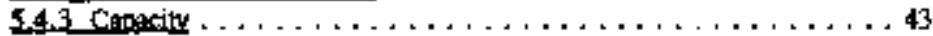

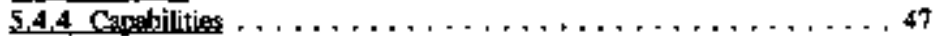

5,5 Valne of System $\ldots \ldots \ldots \ldots \ldots \ldots \ldots \ldots \ldots \ldots, \ldots \ldots$

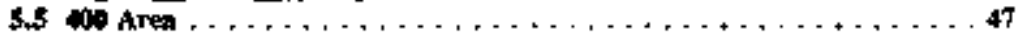

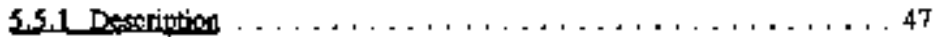

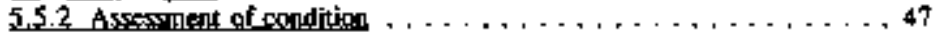

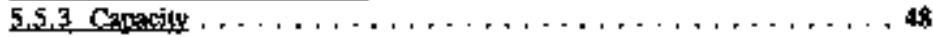

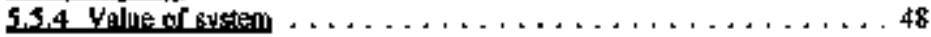

5.5 .5 Mainterance costs $\ldots \ldots \ldots \ldots, \ldots, \ldots, \ldots, \ldots, \ldots, 4 \$$

5.6 Costamer Expectedons and Requbrenents . . . . . . . . . . . . . 49

6.0 HLECTRICAL DISTRIBUTION CAPACITY AND FORECAST MODEL . . 51

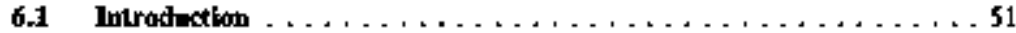

6.2 Total Slte $\ldots \ldots \ldots \ldots \ldots \ldots \ldots \ldots \ldots \ldots \ldots \ldots \ldots \ldots \ldots, \ldots \ldots \ldots$

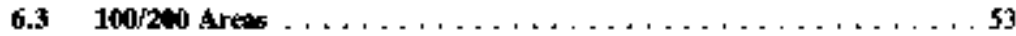

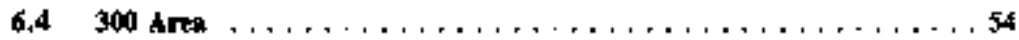

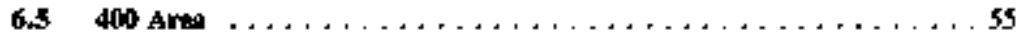

7.0 FUNDING AND RESOURCE PROJECTION MODEX $\ldots \ldots \ldots \ldots \ldots$

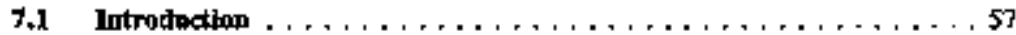

7.2 Staffing Forecasts and Fundling Regulnements $\ldots \ldots \ldots \ldots \ldots \ldots$ 58

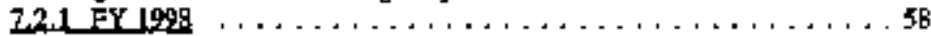

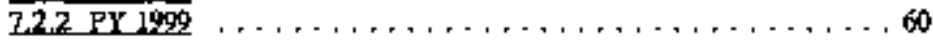

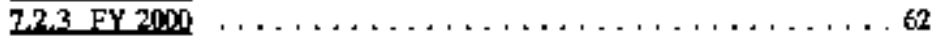

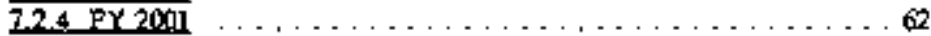

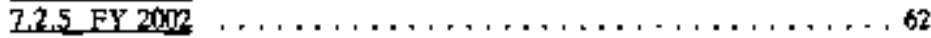

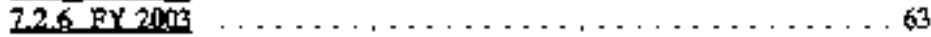

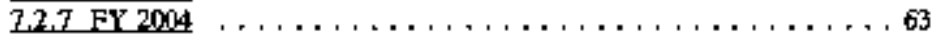

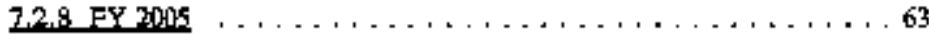

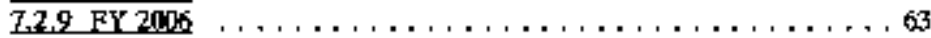

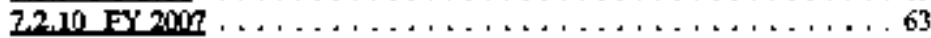


TABLE OF CONTENTS (contlnued)

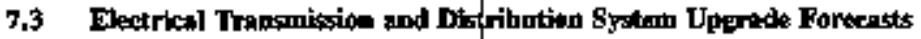
and Fundlng Requirements $\ldots \ldots \ldots \ldots \ldots \ldots \ldots \ldots$

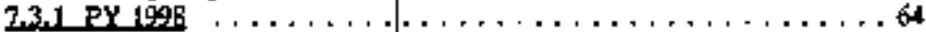

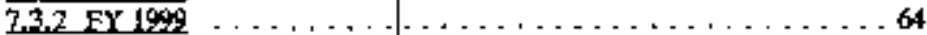

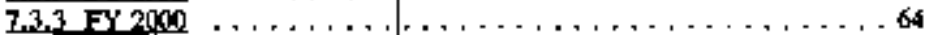

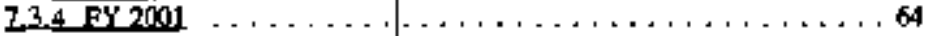

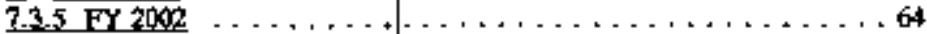

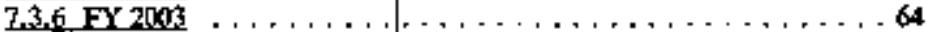

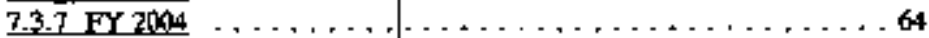

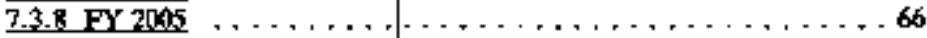

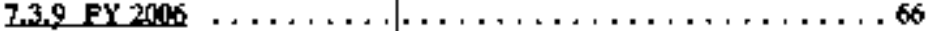

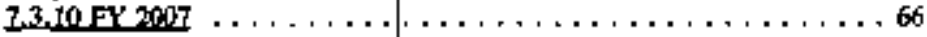

7.4 Caphtal Eqpipopent Forecosts aut Fpnoling Requlrements . . . . . . 66

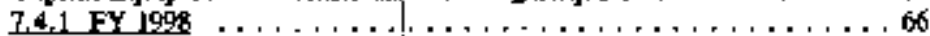

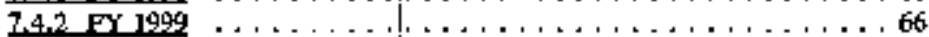

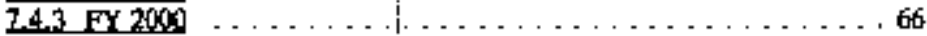

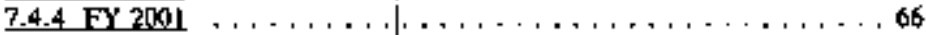

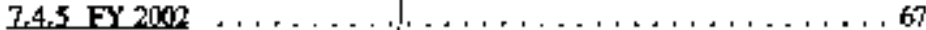

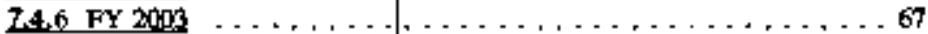

$24 \mathrm{TFY} 20 \mathrm{H}$

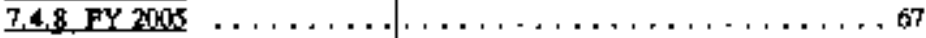

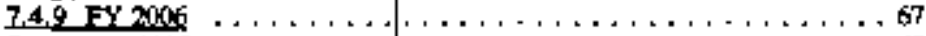

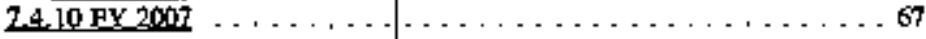

\section{LIST OF APPENDICES}

Appendix $\mathrm{A}$ - References $\ldots \ldots \ldots \ldots \ldots \ldots \ldots \ldots \ldots \ldots, \ldots \ldots \ldots$ Appendix B - Electrical Utilities FY $199 \mathrm{f}$ Building Blocks $\ldots \ldots \ldots \ldots \ldots$ B-1 Appendix C - Project Hanford Site Sumatary Schedule . . . . . . . . . C-1 


\section{LISTT OF FIGURES}

Fig. 2-1 - Rate Comparien $\ldots \ldots \ldots \ldots \ldots \ldots \ldots \ldots \ldots \ldots$

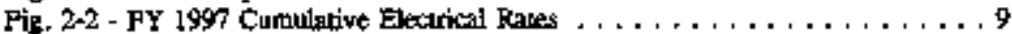

Fig. 4-1 - Electrical Utilities Directilndirect FTE . . . . . . . . . . . . 19

Fip. 5-1 - Hanford Tyansmission and Distribution Systern $\ldots \ldots \ldots \ldots \ldots 25$

Pig. 5-2 - 100-B Ares Transmission and Diptribution \$yzterd . . . . . . . 29

Fig. 5-3 - 100-D Area Tramsmission and Distribution System . . . . . . . . 31

Fif. 5-4 - I00-K Area Transmizsion and Distribution System . . . . . . . . 33

Fig. 5-5 - 100-N Area Transmission and Disuribution System . . . . . . . . 35

Fis. 5-6 - 200-Eagt Area Transprission and Digtribution System $\ldots \ldots \ldots \ldots 37$

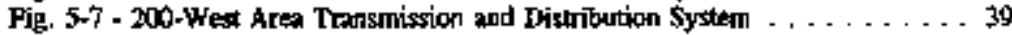

Fle. 5-8 - 300 Area Transmission and Dlstribution System . . . . . . . 45

Fig. 6-I - FY 1996-200'? Total Site Electrical Power Foreast . . . . . . . . \$2

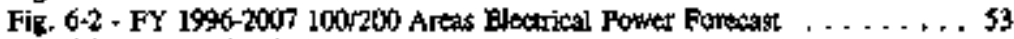

Pig. 6-3 - FY 1996-2007 300 Are Electrical Power Forecsat . . . . . . . . . . 54

Fig. 6-4 - PY 1996-2007 400 atre Electrical Power Forecasl . . . . . . . . . s5

Fig. 7-1 - Electrical Utilities Substation LayuprDenctivation Activities . . . . 6 61

\section{LIST OF TABLES}

Table 5-1 - 100200 Areas Capaclty . . . . . . . . . . . . . . . . 4J

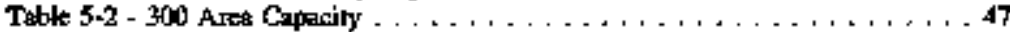

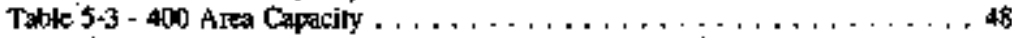

Table 6-1 - Electric Distribution Capacily Data Solute Contionce Level , . . . . 5J

Table ?-1 - Funding and Resource Data Source Confidence Level . . . . . . 5?

Table 7.2 - FY 1998-FY 2007 \$taffint Fortect . . . . . . . . . . . . . . . 59

Table 7-3 - FY 1998-FX 2007 Capital PToject'Bquipment Forecast . . . . . 65 


\section{BLECTRICAL UTIITIES MODEL FOR DETERMUINIS ELECTRTCAL DISTRIBUTHON CAPACTIY}

\subsection{EXECUTTYE SUMMARY}

\section{1,1 Introdaction}

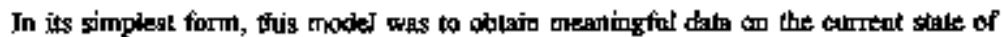
the Site's electrical transmission and distobution asgets, and hum this vast epollectiont of dala into useful informaliors. Major dala inputs and cutputs selected for the moded inchuded:

\begin{tabular}{|c|c|}
\hline Inputs & Oulprul \\
\hline 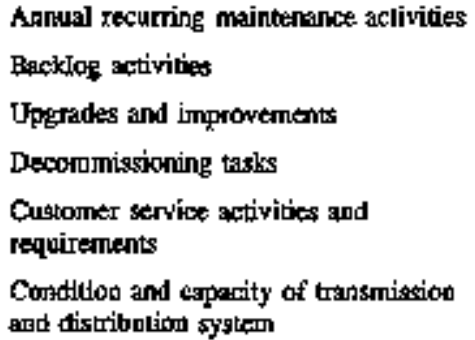 & $\begin{array}{l}\text { Distribulion and eapecity, } \\
\text { staffing, mattrial, and } \\
\text { equipment forecasts }\end{array}$ \\
\hline
\end{tabular}

The lask presented many typicsl obstackes, such as:

- Asset inforthation, while ayajlabje, was sol organdzed iv a fastion comvenient for the compilation of this document.

- The trantimission and distribntion notwork was very diverse and encountrassed a variety of types and desigas of structures, and dozens of types or designs of Dompontenls.

- Average line age was approaching 35 years, with the oldest line over 50 yeary.

Existing documentation, including studies, memos, and lecters, was used during the research of this model in an effort to better uthlize taxpayers dollarg.'

\footnotetext{
'Refer 6 Appendix A for a lish of neferences used during compitation of this model.
} 
The resulting product is an Eleotrital Uilities Model for Determining Electrictal Distribution Copacity which prowides:

- current stite of the electrical transmission and distribution systens

- crilical Hanford Site needs based on outyes planning documents

- dexision factor model.

Thuis model will mable Electricat Utilities managiment bo improve forecosting requirements for service kevels, budget, schedule, scope, and staflling, and recommend

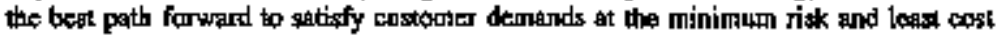
v the gowemment. A dynamic docucrent, the model will be updated annually to reflext changes in Hanford Site activities.

\subsection{Probutive Reengimetring}

DynCorp Electrical Utliules, whth centralized control on a pay-as-ycu-use cost distriburtion, provides safaty and economy that cannot be makbed by decentralization to the programs, as well as timelinessiresponsiveness that cantor be matched through oulscrureling. This was demontstaded by the ageressive, FY 1996 cost reduction

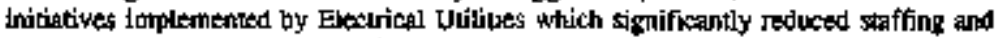
costs. The group's allocation of Siteride assessuxents, including occupancy, dosimetry, contracls, medical, and fleet, were challenged. A rovitw of labor lixuitation practices tonfirmed that mogk services provided by Electrical Utitities are approprintely borme by the entire Site. However, as some job requests are attributable to the buodget of a particular factlity, labor and materlals required for perticular facilities or projects are now charged diractly to that project or facillty, includinis 24hoor electrical dispatesker coverage axd escortssnndby services. The mainkenance program was atralyzed and compared to industry prestices. Critical lads were identified and thaimtengance reduced where impact of outages was low. The work management process wats analyzed, and the procedure simplified, saving time and money. This methodology also aligns with Fluor Daniel Hanfond, Inc., pooformance messures regarding foresasting econonies, as well as the DynCorp mission of optimization of Site support service and rates.

The group's efforts wese commeted by the Department of Energy, Rietlomd Operations Office (DOE-RL) in se-entineering the coperating methodology while contimuing to maintain a sofe, reliable and cost-effective atility service. Coskcurrently, Depariment of Energy. Headquarters ( $\mathrm{DOE}-\mathrm{HQ}$ ) eonsultants concluded that Elecirical Utilities had capabiliues and browledge which appeated to be unusually good for this type of facility, and stafting Ievels were reasonable. 


\subsection{Recomendations}

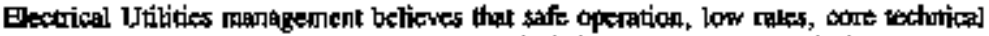
stremgths, and excellent custoner service will dittinguish Electrical Utilities as the preferied suppitet at the Hanfort \$ite.

Capital investonents and operation and rainkenarce expenditures must be mimimized to hold down tlectrle rales, and Flectrical Utllttes contimxes to hold down costs to

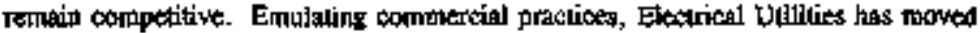

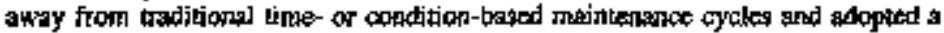
more reliability-based maintenance program withoul jeopardizing personal and system protection activities. Although an experienped glaff is the vingle mogt important factor in mainteining reliability, expenses are also kept in check with reduced stafting kevets. However, if Electrical Utilites cult custs too far, the abiliy to supply reliable power to customers will be jeopardized. The organization's gurcess will hinge on the ability to balance capital tnvesiment wilh approprlate system matnitenance expendituret.

Electical Utilities will continue to evolve in response to the shanging utility

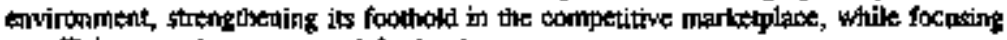
on efficiency and custaner satigfaction by:

- delermining when existing substations are no longer cost effective to operate

- subusitting requegts and budgetg to deactivate substations with a comrefponding decrease in batklor maintenance and infrattucture

- assessing the need for altemate coutings when nuclear safely criteria or high Jeliability for long term experiments ate no longer requircd

- Increasing remaindng subscadon capacity utilizarion

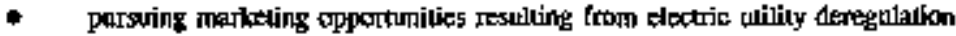

- continuing to move toward begt corameacial practices where allowed by DOE requlrements and compory policies

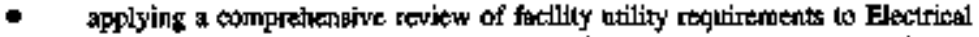
Utilities preventive, predictive, and corrostive masintenance to ensure physical asset availability for plamed use

- pursuing energy savinga ogportunities within the Utilities division. 


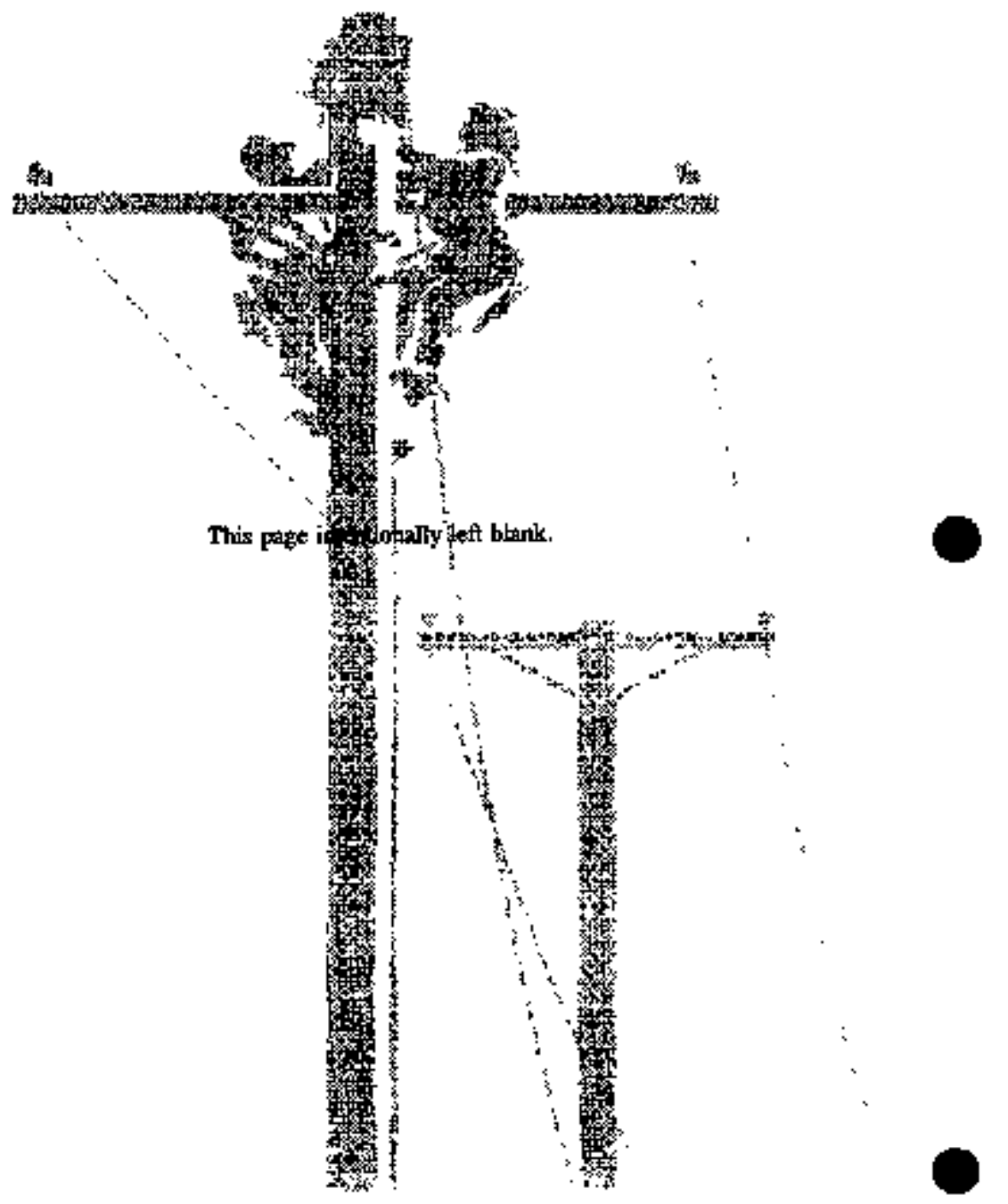


2.0 GOAL

\section{$2+1$ Go:k}

- Operate the electrical ulijily system in a safe muanter.

- Majntalo operation and matntenance rato as kow as reasonably achievablo to remain comptitive with locel arsea utilitios while providing needed servites at an acceptrble reliabilify kre. Use axcepted industry standard prectice of cost

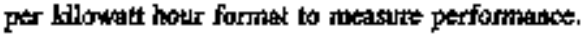

- Provide additional tervices as requasted by cuskomers on a direct funded, work order basis beyond thase which a ntility routiondy provbdes.

- Maintain core infrastructure in order to contimue to meal \$ite mission.

- Contrive lo move toward besi commercial practices as allowed under DOE rules and cortupany poljocies.

\subsection{Objectives and Stratezies}

The primary objective of Electrical Utilitied is to ensure that safte elextrical enetgy is available where needed to stupporl cleath up activities on the Hanford Site. The stocondary objective is to reduce the costs associaled with providing the elextrical entroy to the aclivilies. Straligits to achdeve these objectlves include:

- Maintain those elements of the electrical trapmission and distribution systern that are reguired fim preseal and future cleamup activities on the Hanford Site.

- Modify or upgrade the system where changes it the electrical demand and/or

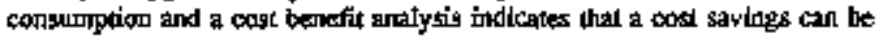
realized.

- Expand the systera capabilitiestcapasity in support of aew projects where required and huaded by the benefitting project.

- Reduce infrastructare wivere nó need exists, and persocal and system protection activities will not be jeopardized.

\subsection{Perromance Measure}

Hanfond budgetary and mandigoment priorities now require allocation of utility cogts is accoriance with deanend for resources, promotion of efficient resource use practices, and a ganeral appreach w infrastructure issues that entlates private sector practices. Electrical Utilities' present liquidation method represents a combercial, businesslike approach we cost fecovisy of the cost of buying electrical ponver plus the distritution 
cost associated whth operatlons, engingering, and rasintenaince of the transmissior and distribution systems. Both costs are currently transferred to the various prograns by billing on a metered or estimated bagis. ${ }^{2}$

Historically, the congl of proyiding ponwer to the Hänford Site bas beed bigber than rake charged by lacal and other U.S. utilities to commencial facilities (see Fig. 2-1) ture to:"

- a transmistion and distribution syotem spcead over a large poceraphical ana (560 square miles) with a low and gradually decreasing density cuastomk base to cover costs

- special capactry vs. utilization cousituations telated to the freed to madnain I00 percent continuity of service in resporse to customer needs

- security and safeguard measures regatired to protect national assets

- DOE and govermment contrमctir requirements governing condust of operntions, mainganse, worker and customer safecy

- protection mesaures related to working around haxardous and pafiogactive facilities and ormlaminated areas.

${ }^{2}$ Estimaks are adjusted at beginning and mid-fiscal year. All cugtomers are in one rale elassification. Capitral costa are not inchuded.

'Comparisons between Electrical Utilities and other electrikal utilities and eveo other' DCE site utlilly organizations should be done vilth caution as each unlity has onique service territory characteristios, customer loads, and organizalional strucures which may intluence the expense rattos. Ho other DOE site has an electrkal bilities syseem; ralher, ocher DOE sites are sirnilar to industrial campuses using indughial maintanance electricians.

Wtilities are staped signiffeanlly by the culnure of the customer, and Electrical Utilities is certainly no mocption. At best, the transtrission and disuribution syatem could only be 50 percent utilized to provide 100 percent redundarcy at selected facitities. Previous studies atempted to comjore Eloctrical Utilities' maintenance and operation costs to a 1.2 cents per $\mathrm{kWh}$ operalioms and mapinteoance (O\&M) tate, a value based upon utilily industry practice and similar to the ayerage 1.17 oents per kwh odel cost (excludes proxthetion and sales costs) from a survey of 160 major investor owned electric utilities resentiy released by the Utility Dan Inttituke. Howtwer, investor owmed uilities don't have to comply with DOE radiation requirements and maintain 100 percent redundancy at selected fasilities. Investor owned uilitics will prowlde adlitional services but al extra coss. Survey information oblained from Fedtal Electrical Regulatony Cormnission (FERC) Form No. I reports ssabmitted on an annual bassis. 


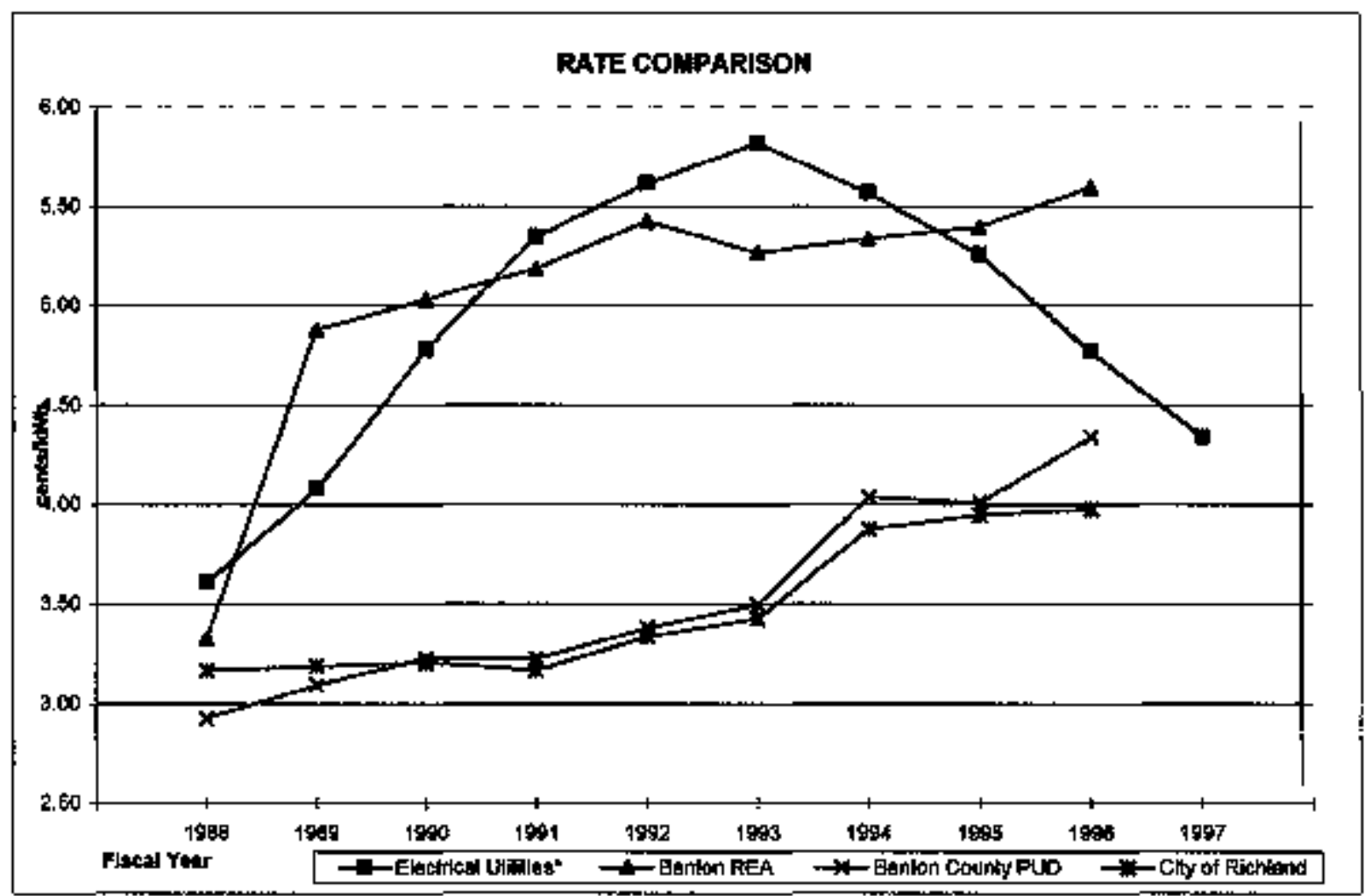

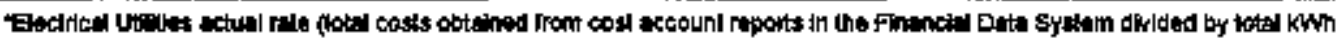

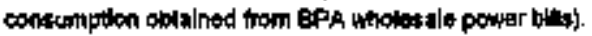

FIG. 2-1 
A significterth decriease in the Electrical Utilities rate occumed Auring FY 1996 (ste Fig. 2-1). Two activlties, achieved durjing the month of May, were responsible for the dxarnatic reduction:

- an agsrassive cost reduction canpaigo implemented by Electrical Utilitieg,

- an evaluation of a different rate structure. Azsesments such as oxeupeacy, landfill, transit, site services (janitor, weed and pest control, etc.), fire systems, BPA allocations, and PCB contract work, wert exclnded bectause the cosas would renain evert if the Electrical Utilities fortelion was ontourced to arother utility.s

The FY 1997 perfornance measurement goal for Elecrical Utility operaion and distribution costs is 1.4 cents per KWh. Through June [997, this rafe is 1.412 cents/kWh, and the ctumlative average cast of purchising BPA power is 2.402 cents'kWh, for a total coos of 3.814 cents/kwh to the Sile user (set Fig. 2-2).

${ }^{4}$ The FY 1996 Electrical Utillies rate pas approximalely 9 percent less than the FY 1995 rate, the largest ansulal drop of the dewowated trend which began in FY 1994.

'These costs are excluded from the Electrical Rate calculations bastod upon instructions pHovided from W. A. Ruthefford, Ditecter of Site Intraftroseure Division, DOE-RL, datef 3/B 96 , Ref. No. 96-SLD-009. 


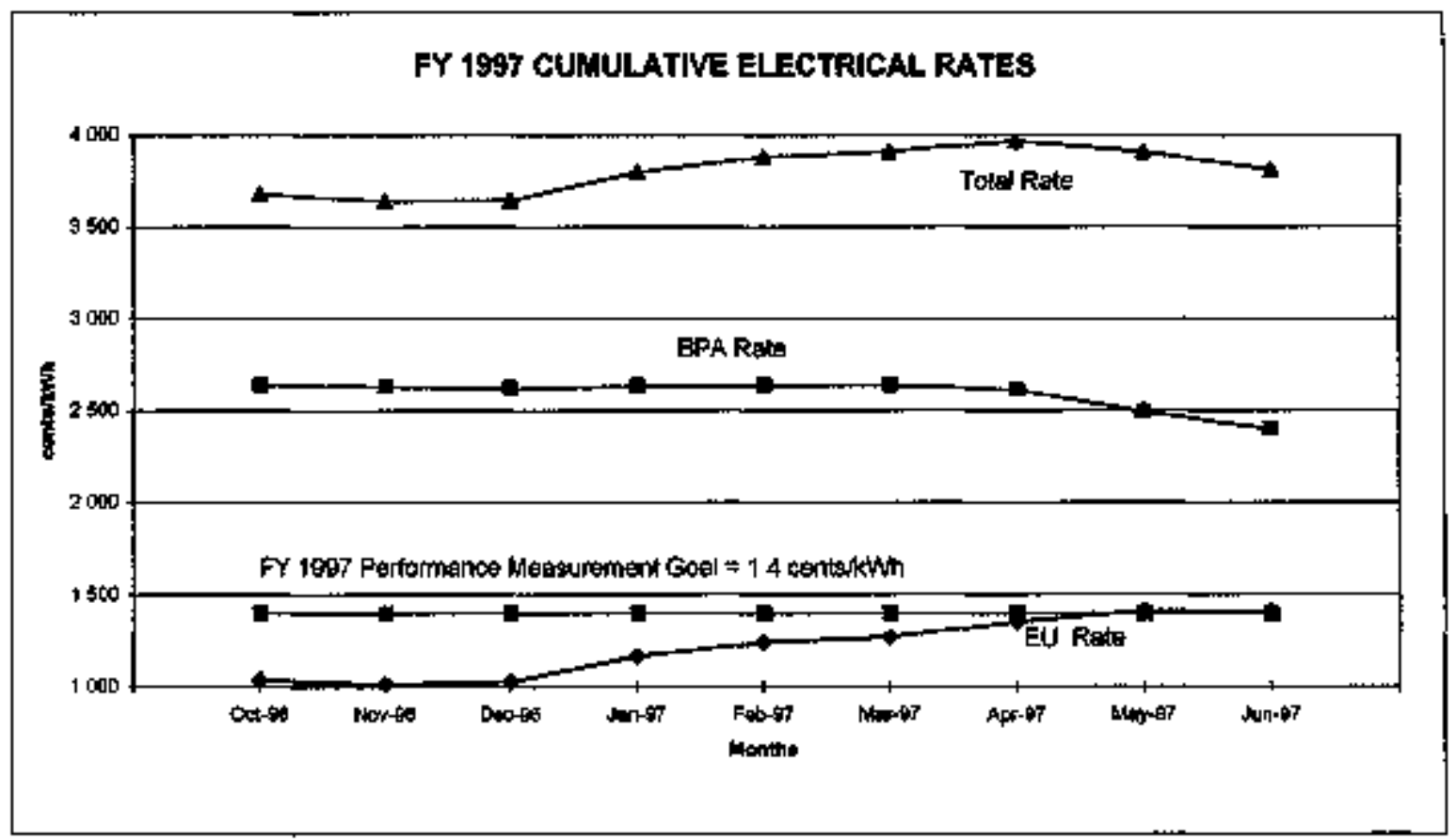

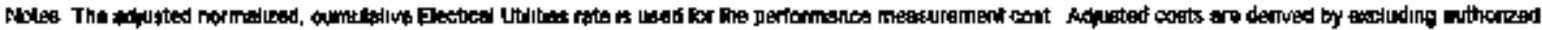

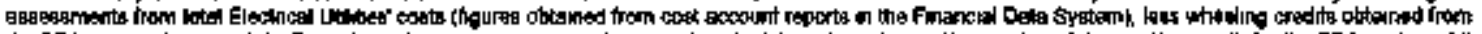

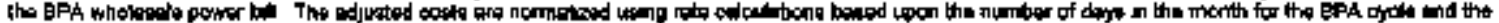

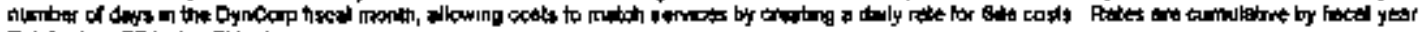

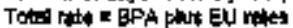

Fig. 2-2 


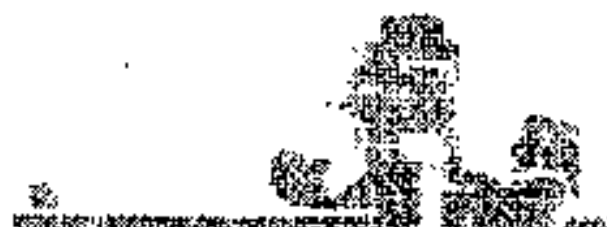

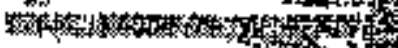

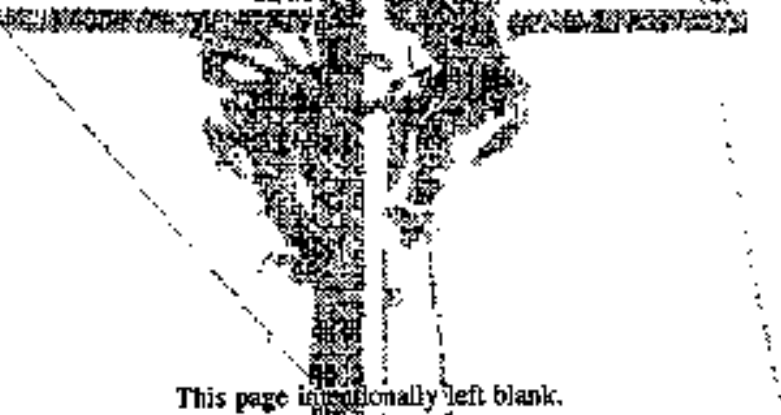

paze inuxulomaly
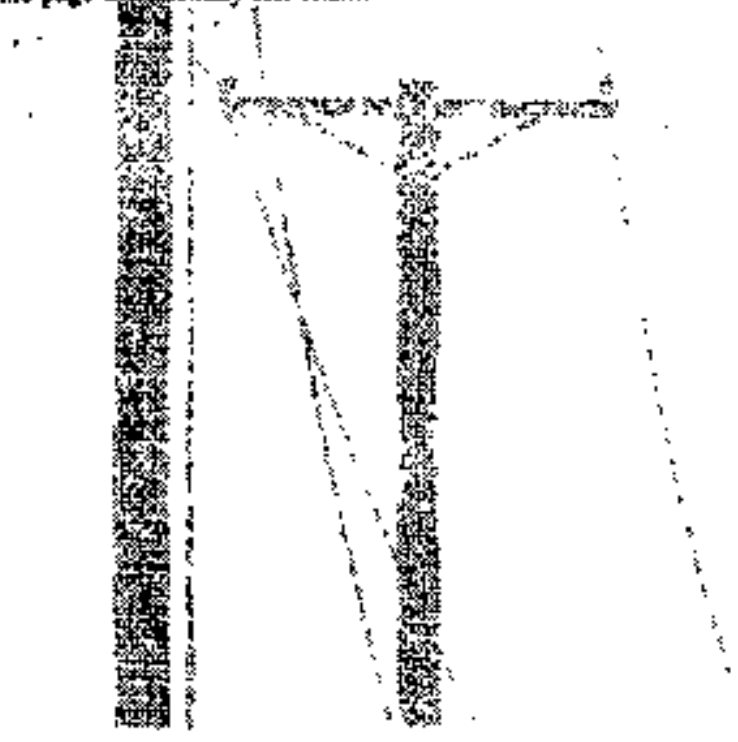


\subsection{REGULATORY REOUIREMTNTS}

3.1 Stondards, stale and foderal regalotions, and U.S. Department of Eatry urders wsed to weasure nytem performance and condition

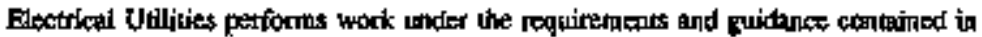
the Nationat Electrias \$afety Code as implemented by the Washington State Electrical Safery Code, DOE Odders and Directives, Project Hanford Manapement Costraxt atid Dyscorp policies and procedures, refecenced consensos standands, and selfiriraposed best management proctices. Crikeria for operation are also established in the "Policy of Hanford Electrical Power Management Prugram, "Rev, 3, May 23, 1986. The primary goal of inplemenling these requirements is to mainladn a higjty reliable delivery gysterd that is reppongive to the facility customer's neets, with emphasis on safety and proper utilization of resources. Sorne of these requirentents are in addition to those requiremests listed in the Project Hardord Mantagensed Contrac, Part lli, Section J. Appestix C and are considered important for determining the size of the baseline workforce. Some matrixed professional support is neceseary to rerlfy complionce with these regufations and nequirements. Noncompltance no soune standards could result in fites and penallies.

- DOE Onder 232.1, Oxcirrence Keporting and Processing of Operations 、 Informatton (9/30/95), establistes a DOE system for identification, cetcecorizstion, notification, analysis, reporting, followwap, and cloteout of acturitences.

- DOE Order 430.1, Life Cycle Assel Manigement (8r24/95), dirteds the plaming, ackuigition, operation, maintenanks, and dispocal of physical assots as vahuable national resturces and the stewandship of these physical assets be accoraplished in a cost-effective manner to meet the DOE mistion.

- DOE Order 430.2D, In-House Energy Management, provides for the managemesl of tenergy use in DOB owned and keased facilities, and vehicles and quipment.

- DOE Order 5400.1, Gerieral Environdental Protection Prograr, Section 1.4.B, Waste Minintication Efforts to Reduce the Yolurse and Toxicity of Generated Waskes, regulales compliance with applicable Federal, State, and local environchenal protection laws and regubations, Executye Orders, and internal Dejarartment policies.

"DOE Order 4330.2D bas been comcelted and replaced with DOE 430.2, "In-bouse Energy Management", as of June 13, 1996. This may not be ctflected in the FDH-DYN contract, but should be updated. 
- DOE Onder 5490. 19, [Except Chapter 9), Conduct of Operrations for DOE Facilities, prowides naquirements and guidelines to develop directives, plans, gandior prosedures relating to the conduet of aparations at DOE facilities which should result it tuppoved quality and uniformity of operations.

- DOE Order 6430.1A, Chapter VII - General Desigr Criteria, Exterior Electrical \$ystems, and Chrpter XIII - Energy Conservation and Use of Renewable Energy Sourses, 4-6-89, provides general design cribria or use in the acquisition of une Department's facillites and to establish nesponsibilities

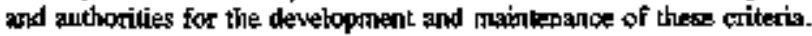

- Federal Acquisition Regulation, Far 41, Acquisition of Utifity Services, Feb. 27,1995 , prescribes poticties, procedutted, and contract formai for the acquisition of utility servlces not produced, distributed, or bold by another Federal agowicy.

- 29 CFR 1910, Occoupationtal Safety and Healih Standarts for Meneral Indostry.

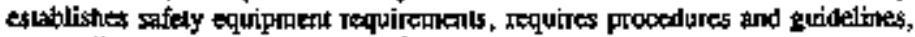
and oultines training requiraroests.

- 29 CFR 1904.1-.22, Recording and Reporting Oxtupational Injuries and Illoesses, prorides for recortkeeping and repowting by employers covered under the Occupational Safety and Health Act of 1970 as nesessary or appropriate for enforcement of the Ath, for developing information regarding causes and prevention of occupational accidents and IInesses, and for maintaining a program of colletion, compilation, and atalysis of occupational safty and bealuh statistics.

- 40 CFR 265. Basic Resource Conservation and Recopery Act (RCRA) of 1976 Operatitug Regutrements, addnesses gemeral operating requirements for owners and operators of facilities that use tatk systems for storing or treation hazardous waste, and specifies hazardous wastes or treaturent reagents must nox be placed in tank if pottl causu tank systerd bo moture, keak, or otherwise fail. Recuires contingency plans os minirnize hazards to human health or environment fron fires, explosion, or any unplanned sudden or non-sudden release of hazardous wasie constiouents which cotsld threaten tauman bife or the environmert.requltes appropryate controls and practices to prevent spiths and overflows. Provides for respontses to leaks or spellls and disposition of leaking or unfit-for-use-tank systems.

- A0 CFR 372.\$力, Emergency Plannimg and Commumily Right-TomKnow Aat (EPCRA) Reporting Requirements, toxic chemical release reponting and communily right to know reporting requirements and schedules for reporting.

- 40 CFR 761, Foderal Polycholorinated Bipheny] Regulations, involyes inspection of PCB Transformers, regulates manufacturing, processing, 
distribution in commerce, and use of PCBs and YCB iterns, and authorizalions for nom-toulaly endosed PCB activities.

- WAC 173-303, Dangerous Waske Regulations, implements chapter 70. 105 RCW, the Hazoudous Waste Management Acs of 1976 as amended in Jgson and 1983, and implements in part, chapter 70.10S A RCW, and Subtitle C of Public Law 94-580, the Resource Cralservation and Recowery Act

WAC 296-45, Safcty \$tandards for Electrteal Wortars (1/97), contains nules

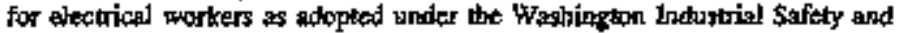
Health Acl of 1973 (Chapter 49.14 RCW). Iochudes minimum leadwork requirements.

- 10 CFR 436, Federal Energy Maragenetul and Planning Programs, 1-1-85, \$ttopart A - "Mithodology and Procedures for Life-Cycle-Cast Analyses"; Subpart B - "Procedures for Preliminary Brergy Audits,"; Subpart C "Guidelines for Eulliding Plans"; and Subpart F - Guidelines for GenenI Operation Elspis" (including an Eprergency Conservation Plan).

- Execulive Order No. 120013, July 20, 1997, reladug to energy policy and constervation, requires the development of guidelines for and the subjaitial of

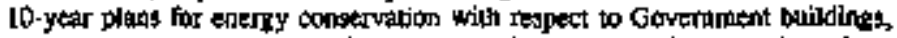
and establishes requirements for encrgy audits and goals for redection of energy use in federal bulidings.

- Nationai Electrical Code, NFPA 70, combains provisionts considered necestary for safczuarding persons and propecty from hazards arising from the installation of elesuric conductors and equipment within or on sIruclures, that conject to the supply of etectricily, installations of other pulside condactors and equipment on the premises, installations of optical fiber cable, and lostallations in buildings used by the electric utlity.

- National Electrical Safety Code, provides practical safeguartidn of persons duriag the indallation, operation, or maintenance of eloctric supply and comnonication lines and associated equipment, as well as bagic provisions that झाc considered recessary for the safety of employees and the public under the specified conditiong.

- Energy Policy Acl of 1992 (Pubjic Law 102-486), contrins new efficitncy provisions for federal faxilities and fleets, and increases use of renewabie energy and altermative fuels.

- Bonneville Power Administration 1996 Wholesale Power Ralte Schedules and General Rale Sthedule Provisions, October 1, 1996, describes the priority firm poner rate (schedule PF-96A) for electricily purchased under the power anks cominact at the Hanford sile. 
- Agreement and Pension and Ingurase A Ereenuent Betwoen Fluor Daniel Hanford Company and Hanford Atomic Metal Trades Council, (FDH 1997)

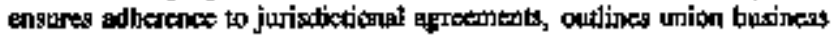
activition, and determines wage raks. Before work (t.g., Electricad Utililies) is contracted out, it must be sutjicted to a "hum down" process. This process does not constder cost as the sole criteria for urmdown. Setiedule and shop

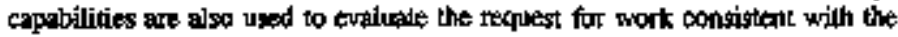
wontracl

The Institute of Electrical and Electronics Bapixetrs and the Waghington Safety Heaith Act require wotk to upgrade facilities and personnted ptotextion, respectively. The American Society of Mechanical Engineers and American National Standards Inslinde also have national standards requirements that effect Elecincal Utilites proceduces, qualification, and certification of procedures and personnel maintenance and retention of reconds.

\subsection{Marketing Opportunilket}

Athough masketing opportunitios for Hantord regulaing from electric utility deregulation and the abollty to evalusite alternate power peneration resources are still years away, there are two batic optiont:

- DOE-RL is a federal agency and receives priorily firm power from BPA. This is the game whobesle rate scthedule that public utility districs and muricipalities purchase power from BPA for resale to their consumers. The preseni 20-year coniract, established in 1982 atad lesting unlil 2002 , bas rate schedules which are revised every two to fiye years. Monttas prior to the conclusion of the extsting corlsact, DOE-RL will be able to negotiate a pewar contract with one or more elestrical providers. Other local utilities have alreaty initiated up to 15 percent of their powter regltirements with other than BPA with a correspomiding sovings. ${ }^{\text {? }}$

- Wastington glate guidelines for the transition to dexegulation have yed to be set by the state legislature. Eventually, odher electrical utility comparies will have the opportunity to wheel power through the Hanford system, providing Dlectrical Utitities with another mpans to liguidate cogts (oftset repontred reke) through new wheeling resenuss

\footnotetext{
THowever, modest increases in transmisstion and distribution experises are projected

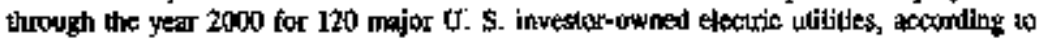

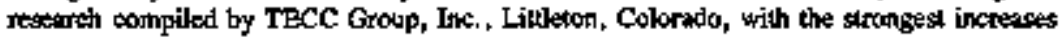
jrojected for the Southweskm and Midwestem states and the West Coast.
} 


\section{BASELINE OPERATIONS}

\subsection{Mistion}

The mission of the Electrical Utilities function is to provide electrical power transmission and distribution services by creatively adapting o meet the needs of the

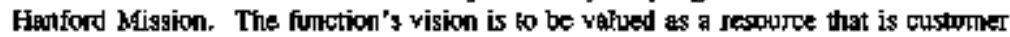
oriented, responsive, cost efficient, ste, and highly effective.

\subsection{Wonkforee Orgsonteatlow}

Electrical Utilities staff घre responsibje for the operation, administration, maintentance, upgrade actuvities, enpineering, and eonfipuralipn managepent associated with the DoE-RL owned Hanford electical transontssion and distribution syaten. The

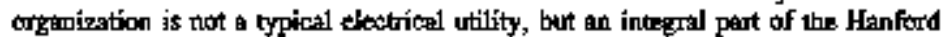
mitsion, challenget to ensure continuity of a highly reliable service, In addition, the specially urained and equipped work force provides a pool of bigh yollage expertise in demand for related customer work ordered servkes, sucb as 24-hour dispacth, facillty elsctrical maintenance, lineman and electrician gtardby support, rubber goods testing. and special outage support for other plank operations. Elestrical Utilities also supports operalions of the Hanford Site polychloringted bjphenyl (PCB) storage for disporsal facility, and handles and processes non-radiological PCB wastes for off-Site shipment. A list of driving requiresmeats for Elextrical Utilities attivities is in Sotion 3.0.

Major services prowided by Fiectrical Utilities have historically been grouped by Optrations, Administration, and Maintenance and Management support. Other organizations or companies proyide support to Elextrical Utilities which must be forecasted and budgeted as well. For FY 1997, the workforce is comprised of 13.8 FTB bargaining unit, 18.3 PTE exempt, and 3.0 FTE nonexempt perionitd, or a lotal of 35.1 FTE." Work ordered customer servlce activilies, not included in the Electrical Utilities cost actount plan, fund an additions l0.3 FTE. Ste Appendix B.

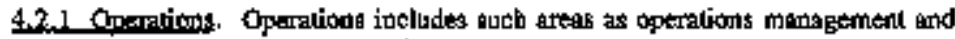
supervision, electrical systed confugoration control, systems potection engineering, electrtcal engineering, and administative support Specific activities include systart design and modificstion, electrical equipmeni standerd specification and development, project reviews, permil development and processing, site selection ankilysis, Ensineering Change Notice (ECN) develotoment, and protecuive coordithation sudies.

Administralive support prowided for a variery of programs includes report preparation, dala analysis, Conrective Action Management, safely programs (i.e, confined space,

"Full time equivaient fugures which include I.3 FTE exempt and 0.7 FTE baggaining unil Support from others. 
fall protestion, astestos, etc.); conducting accident investipations and critiques; porforminc root cause analysts and risk evaluations (PPO), and preparing oceumencelevent reports; deweloping lob \$afety Analygis and Enerized Work Permils; prowding oversight to the wortling-level procedure program, includiog the role as the procecture cosidiralor, direcling the Lock-Tay program and serving as Lock-Tag Administrator; and interfaxing with technical training and other suppost orroganizations.

Also incladed under these services is the aperation of the Superyisory Control and Data Aequisition (SCADA) system, which monttors and provides staus and alarms on peablems assoxiated with the trantmission and distribution syatem. Electricel Utillties operates a 24-bour intinted cendral dispalch station, which prowides a single point of contant for coordination of all elestrical activities om the transurission and distribution system and outage notificalion to facility representative during off-shift hours. The SCADA system allous the dispateber to change eloctrical routings remolely through the primary mo mecondary substations in the event of an catage or failure.

For FY 1997, the Operations group inwotved 8.8 FTEs, as well as 3.1 FTE in direct funded activities. Ser Apperdix B.

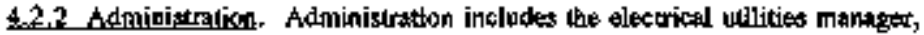
administratiwe clerical support, tochnical support management and supervision, energy

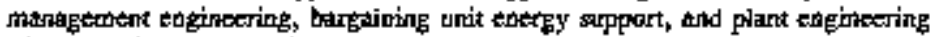
administration and technical support.

Specific support activities include meter rearlings, revies of billings for completenewsiconrectness, individual facility billing, electric usage forecssting,

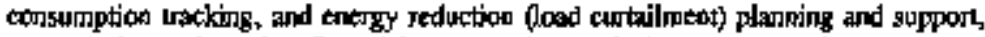
meter design and repairs, financhal support, chla analycs, gmogrammalic support, and setf-assessurerts. In addition, the Administrative group compiles and prepures the Hanford Site Quarterly Eaergy Conservalion Performanke Reporn and the annual Site energy report for DOE-RL, and evaluptes energy savings opportunitieg wilhin the Utilities division,

For FX l9gt, the Adrministration group involved 5.4 FTEt, as well as 0.1 FTE in direct funded distribution activlies. See Appendix B.

4.2.3 Maigtenance and Brangement Suppout. Activities indude bargeining unit supervisory suppont, eltrieal support, planl engineerng suppont, matatenance ou transfoission and distribution equipment; mainten ence esqociated with the SCADA system and other instruments; emergency response support to power outages to restore power and conduct necessary repairs; aerjal support to various electrical creps and plantsf facilities as required; mainkenance support is elentrical utilities subsuations and associated electrical equipment ( $(\mathrm{WWh})$; rest, calibrate, and repais over 300 protective redays, 600 kilowatt hour metters, and 100 field data acquisition sygtem (FDAS) uthis; work managenent planning and schedufing, environmental compliance. 
and material coordinator activities. Otber activities include scheduling building olagges, esecrical switching $(230 \mathrm{kV}, J 55 \mathrm{tV}, 13.8 \mathrm{kV}$, and $2.4 \mathrm{kV}$, meter resing, servire the-iss, facility support (elevaced rork), flrst response to FCBNoll spllls and harardous waste management, tansformer decoutamination and decommissioning/rerooval, and double jsolation for facility lockouls-tagouts.

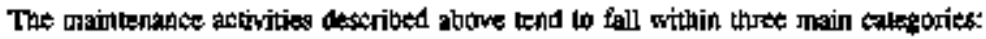

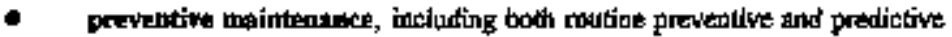
maintenanke activities, which lend to be reasonably constant and predictable from yeor to year and are nockesary to maintain a saft and reliable electrical infiagtruchure systen in support of programmalic activities. As a jesult of a maintenance activity ansiysis conducted in FY 1995/96, activilies which did not impact the bife cycle of the transmission and distributon system or the bealth and anfety of employes were eliminated,

- corredire maintenance, including repads of failed or malfundioning

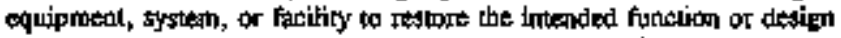
condition. This maintenance does not result in a significant extension of the expexled useful life.

- Tacilities support, jncluding both preventive and corrective maintenance trom: majos programs and other Hanford site contractors.

For FY 1997, the Mainterance and Manggernent Support group involved 18.9 FTE as will as 7.1 FTE in ditect funded activities. Set Apgendix B.

4.2.4 Surpont Eron Dlhers. Services provided by other organizations or companies include designuddafting sapport, drawing maintenance, as-built and documeat contsol: chlotinator, fanitor, pesticide, trassportation, and aeed control services; craft, softwase engineeding, performance meaturtinenl, and leaining suppors; generator

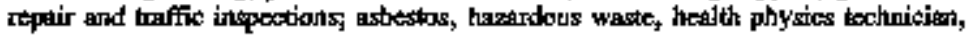
carpenter, frbrication shop, axd excess material support. These activities tertal to bo reasonably constant and prediclkble from year to year.

For FY 1997, Support from Others inwolved 2,0 FTE. See Appendix B.

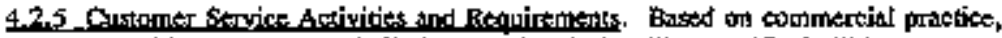

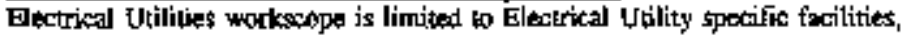
systems, and reports. Additional services in suppon of and as requesued by customers, beyoud those routinkely fumisted by a utility, are provided by Elextrion Utitities personnecl on a direct funded, wark ouder besis. During October 1, 1996, 
through Jume IS, 1997,9 the growp tan in hand over 100 wort orders resulting in 28.5 nov-exempt, 4,451.5 exempt, and 8,119 craft hours, totaling I2,599 manhours, or 9.7 FTE. In comparison, the FY 1997 cost acoomi ptan for the same lime period tocludes 3,763.8 api-exempt, 24,522.6 exenpt, and [8,042.4 craft hours, totaling 46,328.8 manthours, or 35.7 FTE. ${ }^{10}$ This derionotrates the cost account plan contains only $\pi$ percenl of the sork $k$ be performed by Electrical Vtilities loee Fig. 4-1). Crews strive to met the customer need dates 100 percent of the time and conpleke work orders to the negotiated budget. These irdicators geterally bave a high cocrelation to the customerts tatistation.

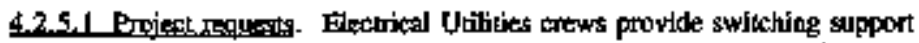
to prowide saie wodk areas throughout the Site for subcontractors conducting

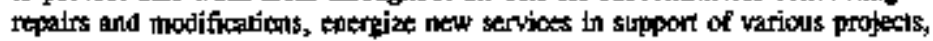
incluting new clesnup facilities, disconnect elestrical service to facilities in tiosely support of deactivation and decommissioning activities, and sopport PCB oil abipments. Funding for these requests originales from each facilily"s budpel

Twenty-lhree FY 1998 Landiord Program Site inftastructure projicts remain within the current arget funding level. Eight (35 percent) of the projects maty potentially require Electrical tibilities crews. The estimated FTE requirements have been incorporved in the FY 1998 building blocks forecast included in this model.

Several other projects posentially involying Electrical Ittilites crews have been ldentified from the activity descriptloos in the Project Hanford Suarmary Schodule. The extirnated FIE requiredents bave been incorporaled into the foreosiss included in this model.

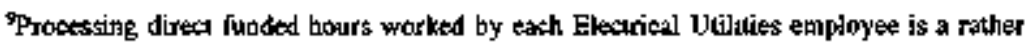
labor intensite process. To promole the most efficient use of time, employte productulty, and complete the Model by the DynCotp targeted milestone due date of Augugt 29, the work order dala cornpitation was performed during the third week of June.

${ }^{10}$ Full time equivalent numbers notod in settion 4.2 and in Appendtx B are average for the fiscal year. Work ondered customer service and Flectrical U'tilities cost accoudt plan activilies cannot be kevel leaded throughout the fiscal year. The amount of direct funded work versus cost accoum plan activities scheduled ach month is based upon a yariery of fartors, including customes requests and weather. Most direx: funded work is accomplished during the suminer months, a time period which is not jacluded in this dala groppshot. 


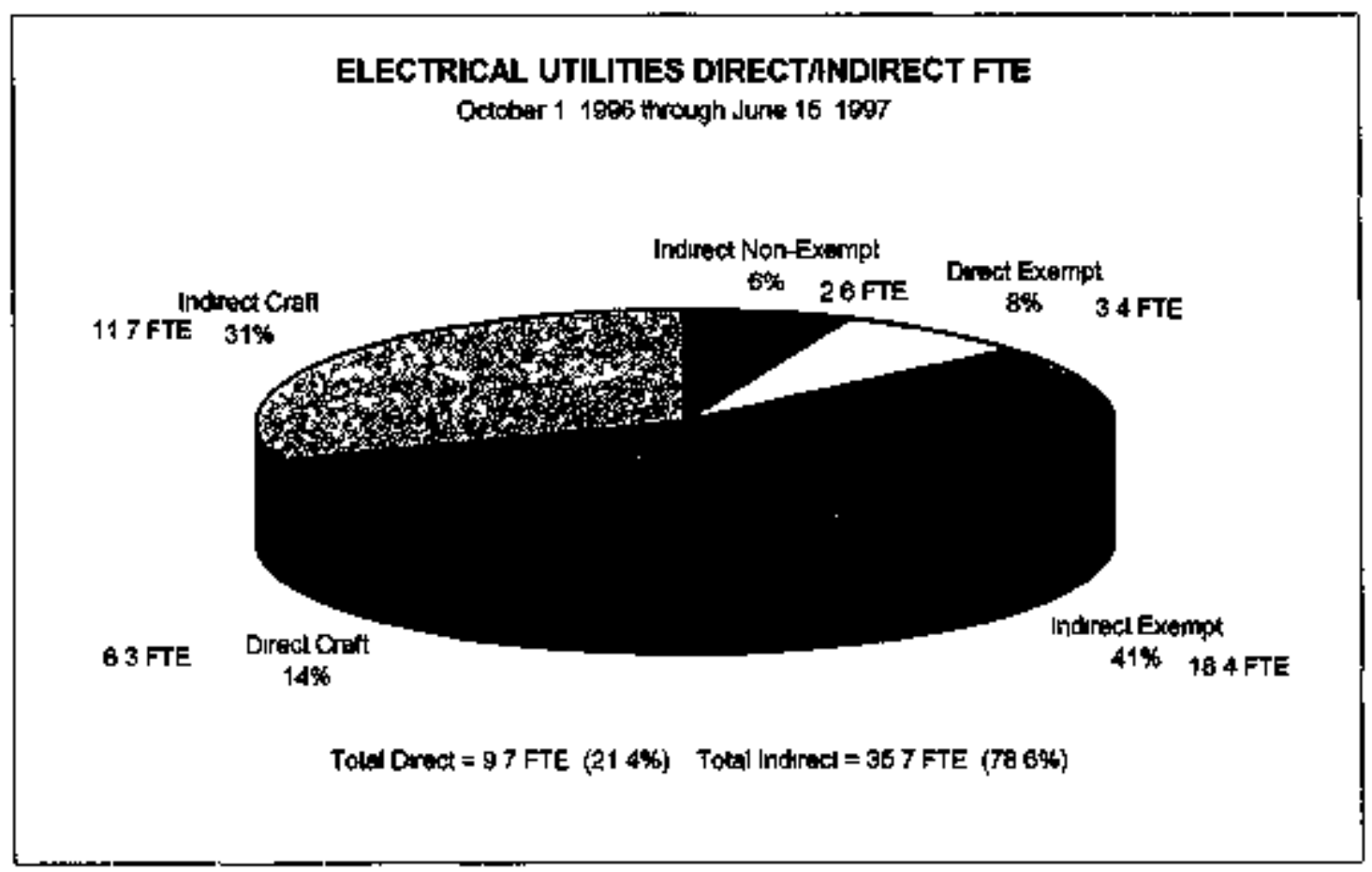


4.2.5.2. Walk-n renuksts. In addition to loown celstomer strivice activities, ot -demand to kevel-of effort tasks mast be allowed for in planning customer requirements, although the tasks are trascosbly constanl and predicbable from year th year. This work may come from major proprams, but historically comes frot other Hanford Site contractors and includes obtage tupport, relay and meter calibrition, rubber poxds testing, cable and transfortinet tenting, PCB oil response, and other customer requested activities.

Using the activity descriptions in the Project Hanford Summary Schectule, Electrical Uilities mantagement identified sctivities which may potentially involve Electriçal Utilitir \$ crews ar d estimateo the FTE requirtments, which have been incorpotated sto the fo ectste inther od in this model.

4.2.6_Future Work Orsagiza ion. Folk wing comme sid 'l praclicts, Eletrical Utilitits management is prezsuting to trask costs by tr unsutission and tistribntion categories. Enhanced trackling of transmission, distribution, and work for others costs will beconte ayailable troutgh a new work mantagetned" system to be implemedted

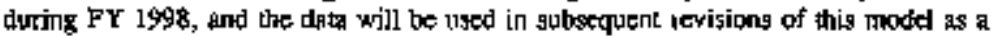
managamant tool to help deteranine approptiate future budget and saffing levbls. An egtimate of 30 percent uransmistion and 70 percent distributson has been factorted into Appendix B. Actual percentages will be khown tohen the new work managentent system becomes fully operational with sufficient datr for analysis.

- Tradsnission calegeries includo 151-E, 151-D, 151-N, 151-KW, 151-KE, 251W, and 351 substadons, as well as trans:nhssion lines, and hejp deternine costs incurred by primary substations. System activitieg include: testing and/or rदpaijing breqkers, switchgear cubjictes, swikchgear bus, potentiad find aurrent transformsers, lightning stresiccs, bith meters, protective telays, and energency lights; and cronductirng visua' and infrared inspeclions of underground vaults, aterial jincs, cables, potes, towwerg, switching stations, switching devises, Itansformers, and coupling caracitors.

$$
\therefore \text {, }
$$

- Distribution ategories include: the 1001-E, 100-D, 100-N, 100-K, 200-E, 200. $W, 300$, and 600 Areas; $252-E, 2 \$ 2-1 \%, 352-E$, and $352-F$ substations; and a Gerieral classification, ald will helf determine onsts incurred by Site areas and secondary substations. Sy sten actiy 'ues include: testing andror repairing

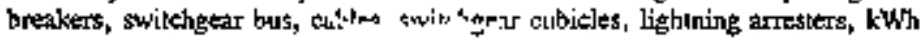

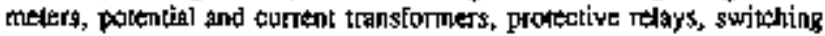
devices, and switching stanions; and conducting vlsual and infrared inspections of underground yaufts, aerial lines, and poles. Cjeneral system activities

ITbe implementation of the new work management system (MAXINO) is driven by RL

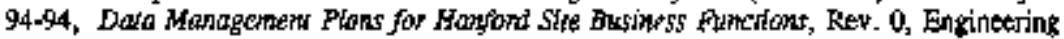
Data Management Plan. Durng FY 1995 , the pilot prosram was established and the data system requirements were ful]y defined and inplemented on a lanited scale. 
jnclude conducting visan inspections of first aid kdts and fire exthigulshers, and vesting andior repagiring batteries, eye wash stalichy, hot lime tools, and rubber goods.

- Work for others categories include the 100-B, 100-D, $100-\mathrm{K}, 100-\mathrm{N}, 200-\mathrm{E}$, $200-2,300,400$, and 600 Aress, and help determine costs inclumed and revenue gencalatiod by Sile arcak.

\subsection{Ecomonite transition meads}

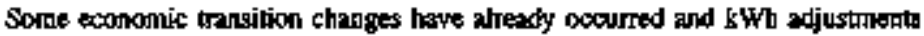
incotporated inb the Hanfond tistribution eapority. These include the Kaiser Aluminum coxtract, whith will contimue through Augrost 15, 1999, and the enterprise corraxanies which resulted from the 1996 Project Hanford Management Contract

The Department of Enessy bas also commiued to deliver up to $20 \mathrm{MWW}$ electrical poster at $13.8 \mathrm{kV}$ for each of the two Tank Waste Remediation Systect (TWRS) privatization facilıties at each contractor's \$ite perimeler. Using the RL $230 \mathrm{kV}$ tronsmission systent to provide power to a thew $23013.8 \mathrm{kV}$ substation is less costy. more IFjable, maintairable, and cperable, and will have kess impact to the environneat than other altemalives. The substation and distribution system in be batit will prowide the reeded electrical serylce to the privatlation facllties, as well as prowide cospabilities for further expension to axcommodak power neteds of future

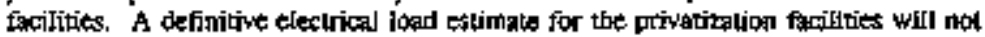
be known until the electricel data are received from the privatization contractor. Although definitive load tota will be provided by the privatizntion contractor(s) after the contrat award, it is anticifould that the TWRS Phase I privatization facilities will reciutic $40 \mathrm{MW}$ by 2003 . The estimated manlour and power adjustinemts have ben fortecasted in Sections 6 and 7 of this model under Project $\$-503$.

In adtition, several potential noceds have been identified by the Econoumic Tramsition Team. The following interest-only activilies may ocaut priot to FY 2000:

- Wastington State Uriversity is interested in 3745 A. $\mathbf{B}, 3745 \mathrm{BrC}$, or 3746/3746A. Antripaled loat is comparable to 3706.

- A large manufactures may use the 3714 building and require IS kVA, 480 V and 2400 service.

- Temporary power will be noted for a erane in 333 South to remove the Lowe press.

- The 324 buiking may be comnercialized (antikipate continukd existing load).

- Crane tuse in the 117J facility would increase if a Jailroad repair company becomes establiyted with incremulal power increscess of $100 \mathrm{kVA}$. 
- Depenting on the outtonate of the FFTF, the 400 Area buildings cosld be ntilized eithes by the Port of Benton or in support of FMEF.

- The infrastmocture also exists for a hazardoas waste facility at the 616 building soquiring a sotill, 40 HVA trantsionter.

Thes potestial activities will not ereale any noticeable increases frotn eststing manhour or power requirements.

Other commercial operations have expressed interest in locating in the vicinity of the Hanford Site, but h areas already desienated by other ubitities, such as the City of Richland, Benton, County PUD, or Benton REA. In thition, cleamup and subsecquent nemm of local controd to some areas of the Hanford Site have the potential to generate noon-fedenal industrial tevelopment. Final Jand use rocomsmendations by a joint federal, state. local, and tribal planning council are due Ocbober 1997, a dale outside

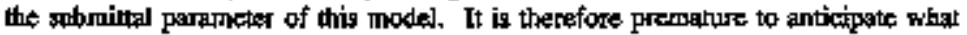
impact these recoumendations for effective use of assets no Ionger required by the feileral goverument will have on Electrical Uutilities. 


\subsection{EASELINE TRANSMISSTION AND DISTTRIBUTYON SYSTEMS}

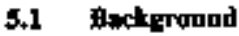

The odginal Hationd Site elextrical Iransmistion and distribution syskem was installed in 1944. Spread oyer 560 square miles, the system ts a fixed asset and cantrot be

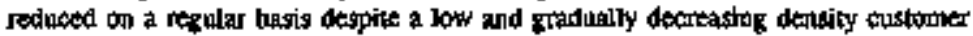
base to cover costs. About do average megawatts (MW), with a peak of $60 \mathrm{MW}$ of firm electrical pstwer, is detivered to Hanford facilities under the special nequinements for meclear safty and is essential to Henford Sitte customers and their ability to conduct Hanford mission specific activities. The system includes approximate]y 200 miles of transouigsion and distribution lines, as well as 11 primary sibstations, 165 (large, capital) transformers, 1600 distribution transfornters, 900 transmission and distribution relays, 68 (large, capjpl) circult breakers, 109 (large, capttal) switches, 42 (large, capial) eubicles, end other exuipment.

Approximately 97 percent of the Site's etedrical power is purchased firealy from the

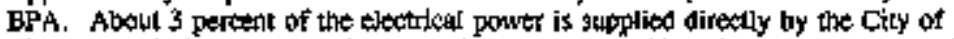
Richland to tacilities in the 700 and 1100 Areas. The City of Richland alpos arpplies power directly to the new Eavironmental and Molectlar Sciences Laboratory (EMSL) and o the Hatrandous Material Management and Emergency Response (HAMMER) facilities in the toutberm portion of the 300 Area. Less than 1 percent is popplied by the Beaton Cownty Public Utility District and the Benton Rural Electric Association.

Major upgrade projects on rtoild the system have taken place since 1978, includiog a program to eliminate PCB oils. Howsever, a few componients of the system are approarthing the end of their useful lives. These will rexquire replacement is decoramissioning, and new extensions from the present system may be required to provide electrical power for future remediation acturltes. In addition, a deuand profila change accurred due to the Site's revised primary mission from production to cleanup. Many of the large transformers and some rnall substaliong, which previously senved active production facilities, are dow drastically undentiltzed.

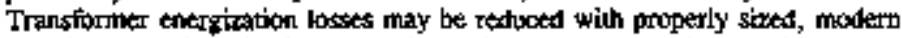
transtordners. Deactivating subgtations will reduce cnergy losses with a contrsponding decrease in backlog maintenance whil increasing temainine substation capacsity utilization. The appuopriate timing for downsizing electrical systems as the cleanup aclivides progress necals to be determined.

Figure 5-1 shows the Bonford Site transmission and disiribution system. 


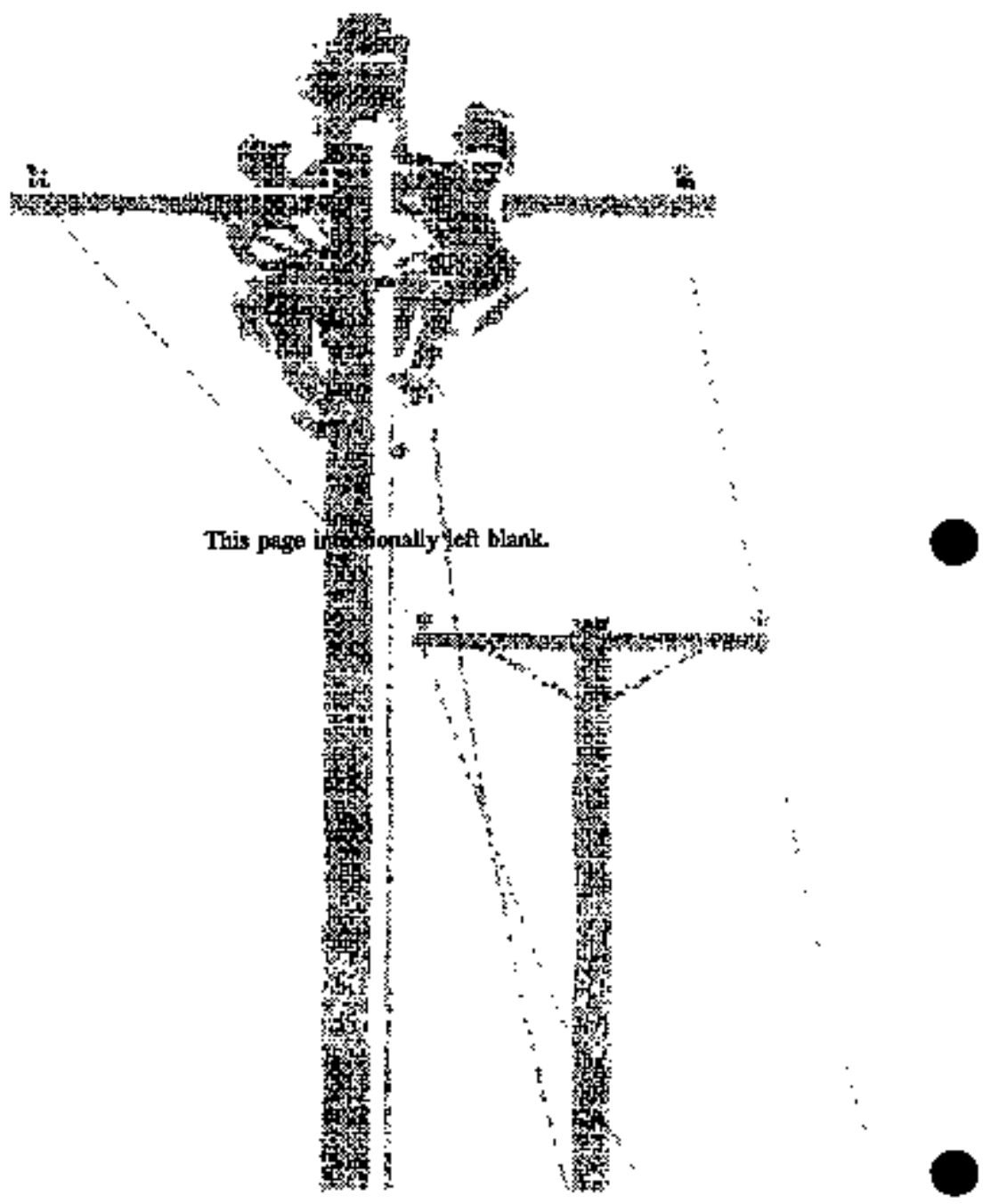




\section{HANFORD TRANSMISSION AND \\ DISTRIBUTION SYSTEM 600 AREA}

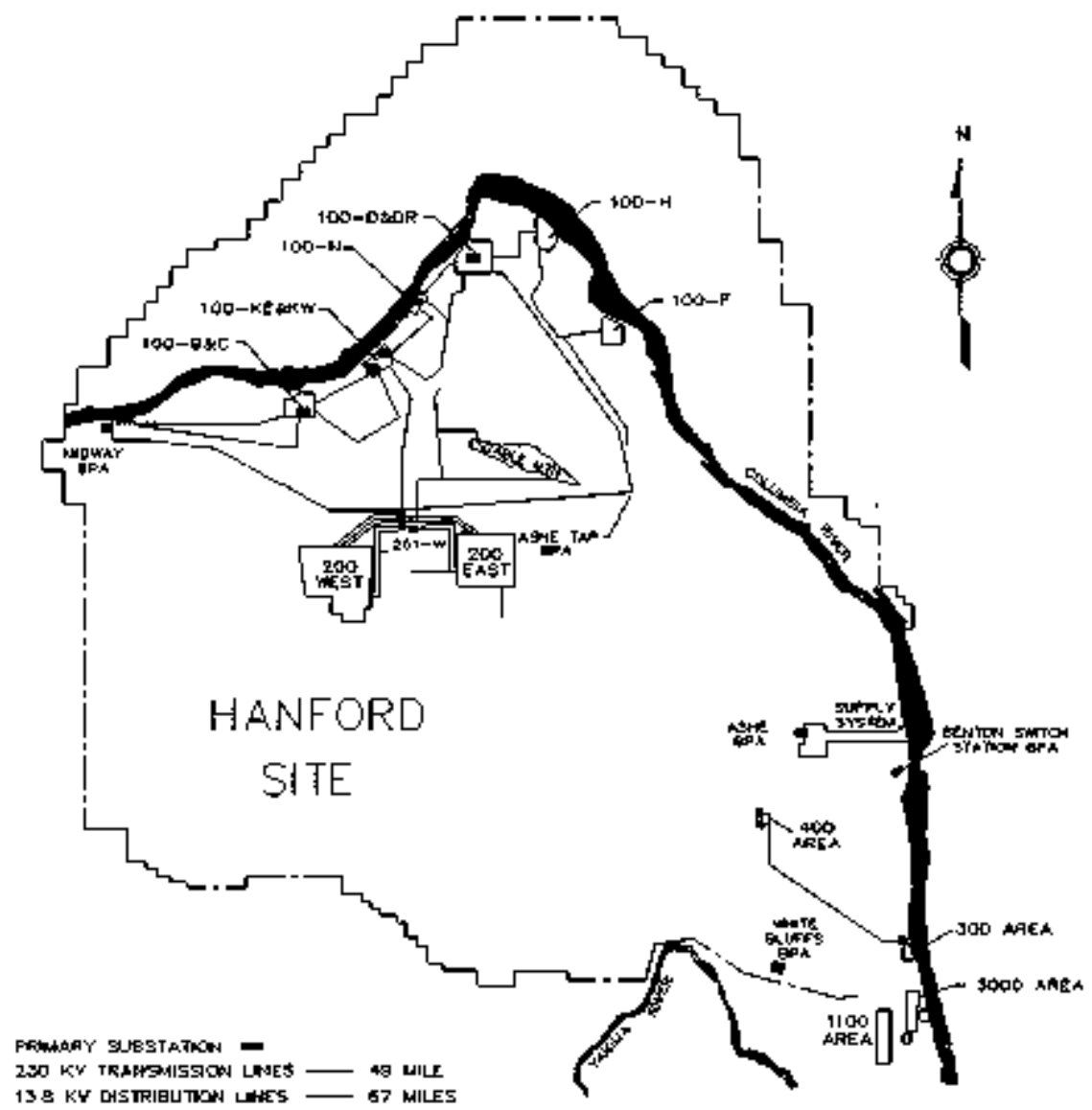
24 KV DEIRIBUTON LNES I NHE

Fig. 5-1 


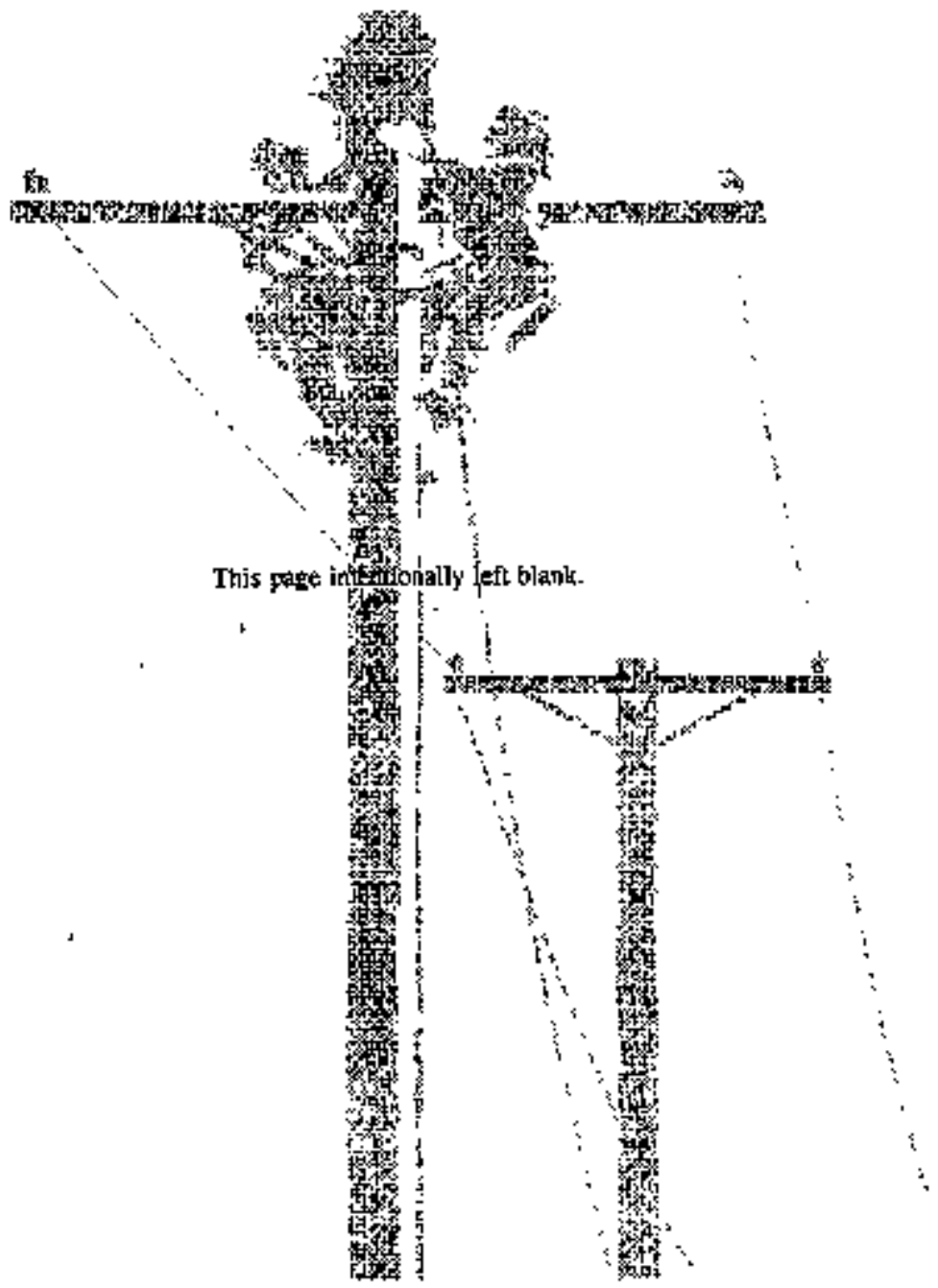




\subsection{0/200 Are⿻ System.}

5.2.1 Descigation. The 1,00/200 Area tectrical transmission and tistribution system is the dectrical network that conveys electricity to facilities in what are referred to as the 100, 200, and 600 Areas of the Hanford Site. The transristion portion consists of high woltage (230 kV) Fines in the 6000 Area that conwey parchased electricity frow ERA delivery points to primary substations in the 100 and 600 Aveas. Distribution refars to the elextrical systams that convey powser (13.8 kV and kower voltage) froc primary subetations to distribution transformers at designated facilities within the areas, Fower to the 1006200 Artas electrical unansuission and tistribution system is provided firom two sources: the BPA Midray substation at the northwest Hantiond sile boundary, and a transorission line from the BPA Ashe Substation. The 100/200 Areas transwisgion and fiatribution systems, as with the BPA soumet lines, have alkitalice routings to agsure electrical service to individual area and designated facilities within those areas. Approximately 50 miles of $230 \mathrm{kV}$ transmiscion lines, stx prtmary substalicosts, and abcul 60 miles of $13.8 \mathrm{kV}$ and 20 motes of $2.4 \mathrm{KV}$ distribution lines derive the syoker.

There is substanlial excess substation capacity in the system to ensute conlinuity of highly reliable service. Esch primary substalion has al keast twhet the capacity of the peak derpand to enable handling the entire load on a single transformer.

Due to the primary distsion change from production to cleamup, the power requirements in the 100 Areas have beten dramatically reduced. The large eletrical derands of the old production reactors and auxiliary syglems are zone. Eariy decommissionisg activities sonetimes abandoned elextrical equipnient in place. Thesa ittems are being removed and dispusead of propherly. As the 100 Ares factlities are dismantled, the associated electrical tistribution syskens will be eliminated. Despite a

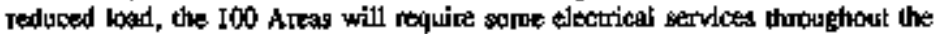
cleanup effort. For exaraple, electrical powwer will still need to be grovided for raw water punp sations which supply water to active areas, ofikes, and spent nuclear fuel storage basins.

Figures 5-2 inrough 5-7 depict the genetal layoul of the $100 / 200$ Areas sysuem.

5.2.2 Assessmant of Condition. The 10002001 Area electrical uransmistion and distribution system is considered to be in very good condition. Given notrual maintenance and rouline reptacements, the systern ghould have a useful life of greater than 20 years.

5.2.3 Canacily. The stx primary substetions have a usable capacity of $195 \mathrm{MW}$, The sygien has a coincidental peak demanks of $34.9 \mathrm{MW}$, thus keaving an available eapacity of 154.2 MW, Based upon demand and comsumpition, the 200 Areat transmistion and distribution system, serving users in the 100 and 200 Areas, is approximately 65 percent of the electricity provided on-\$ite by the Electrical Utilities group. Table $5-1$ provides a bealkowit of the 100 and 200 Areas capectly. 


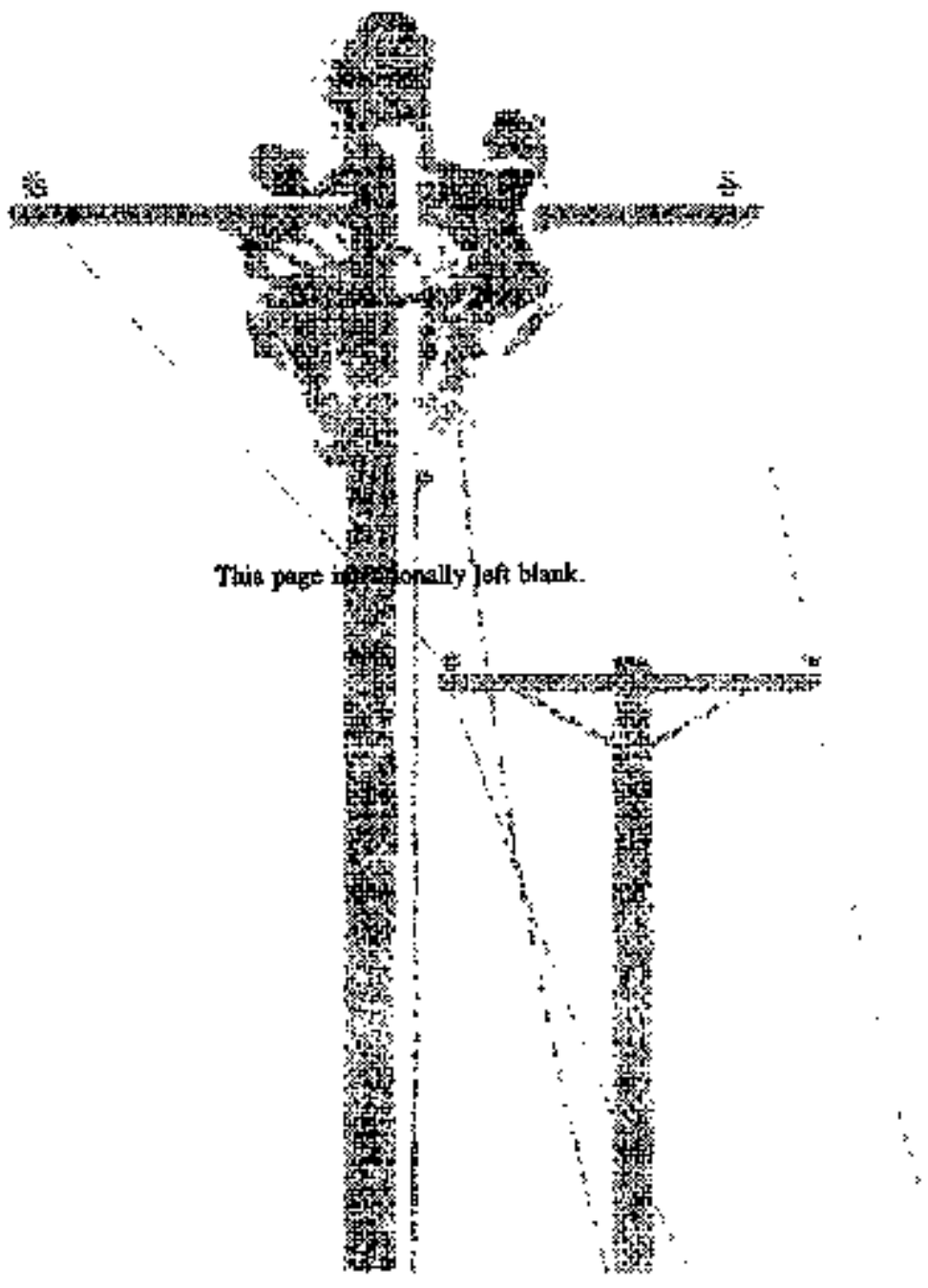




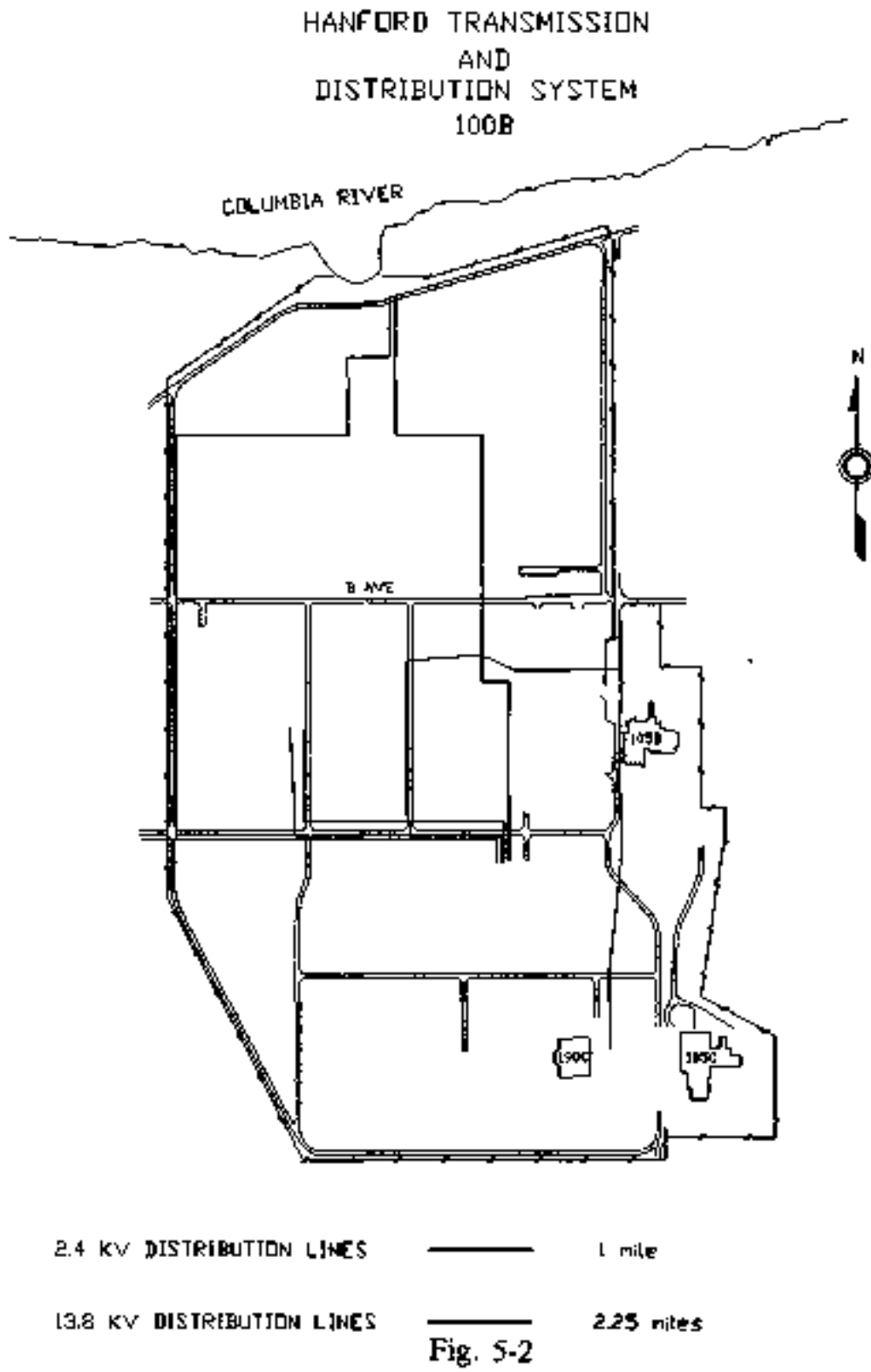




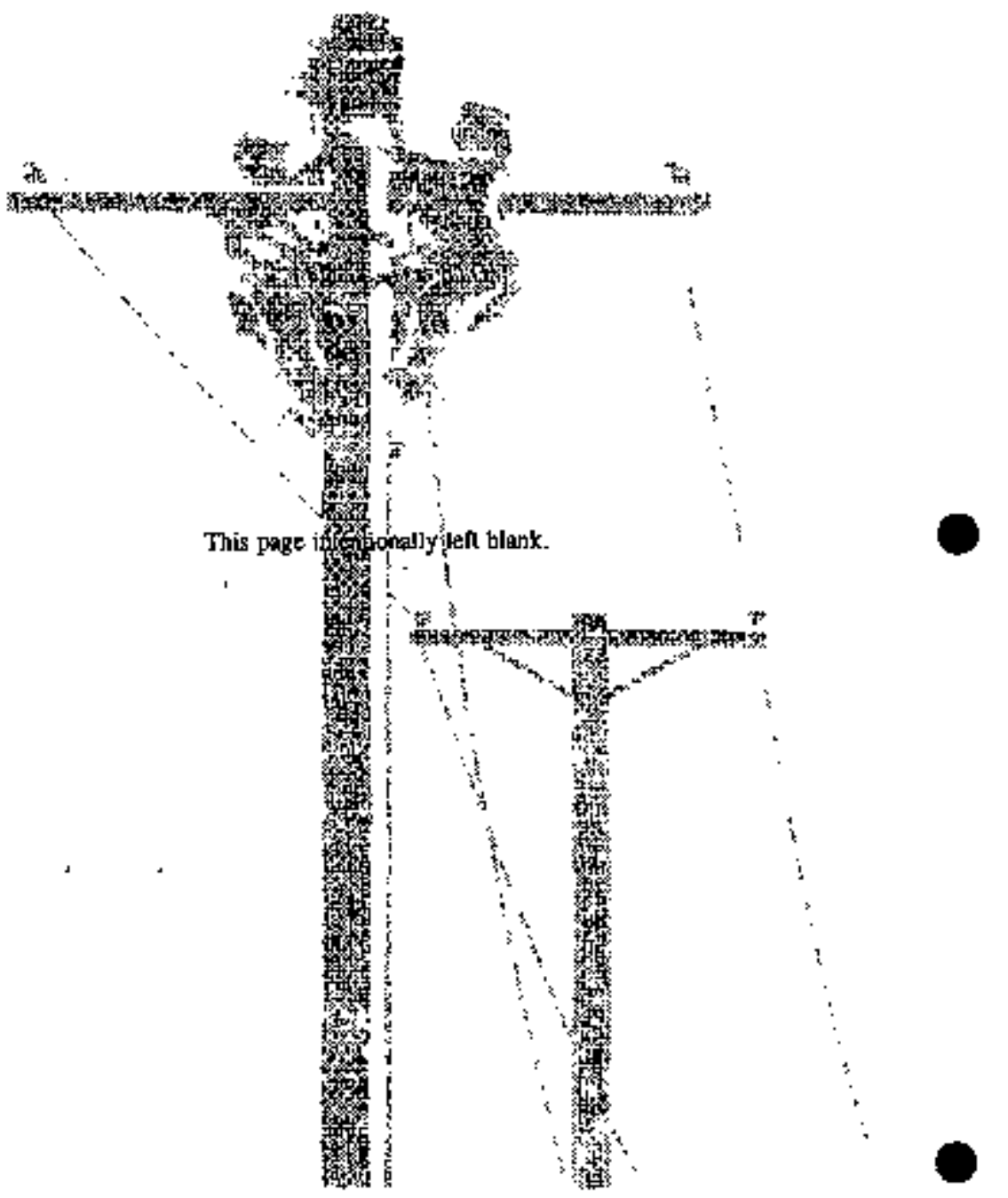




\section{HANF URD TRANSMISSIDN AND DISTRIEUTION SYSTEM $100 \mathrm{D}$}

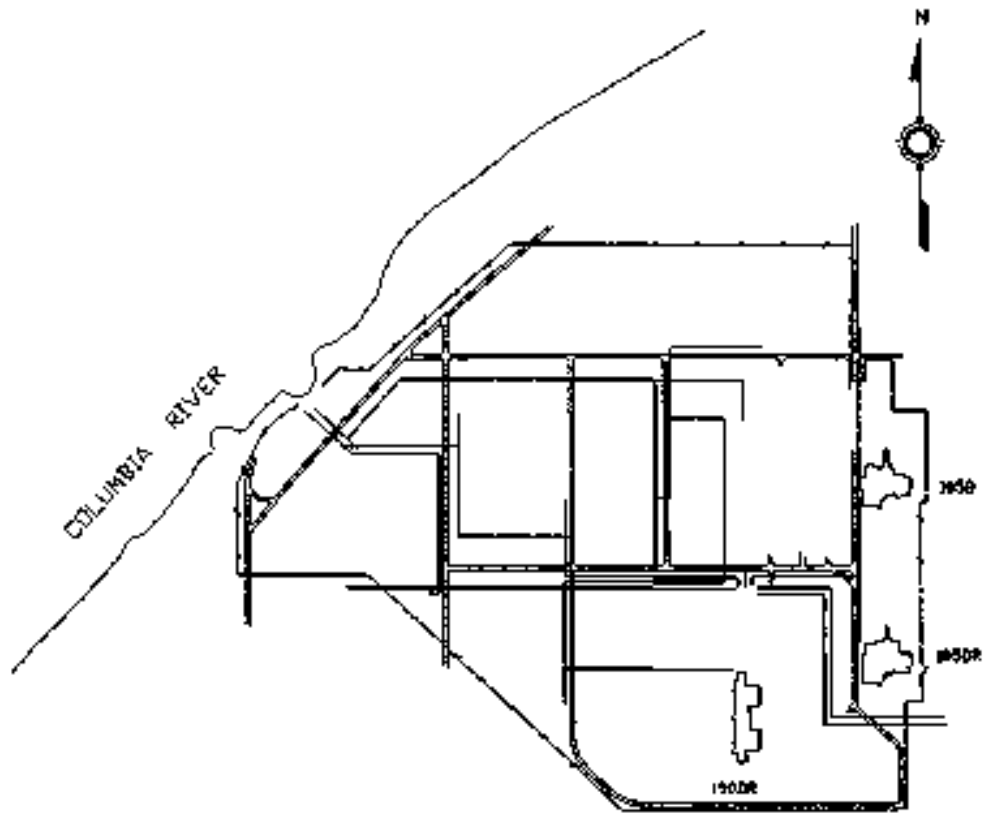

2.4 KV DISTRIEUTION LJKES

Fig. 5-3 


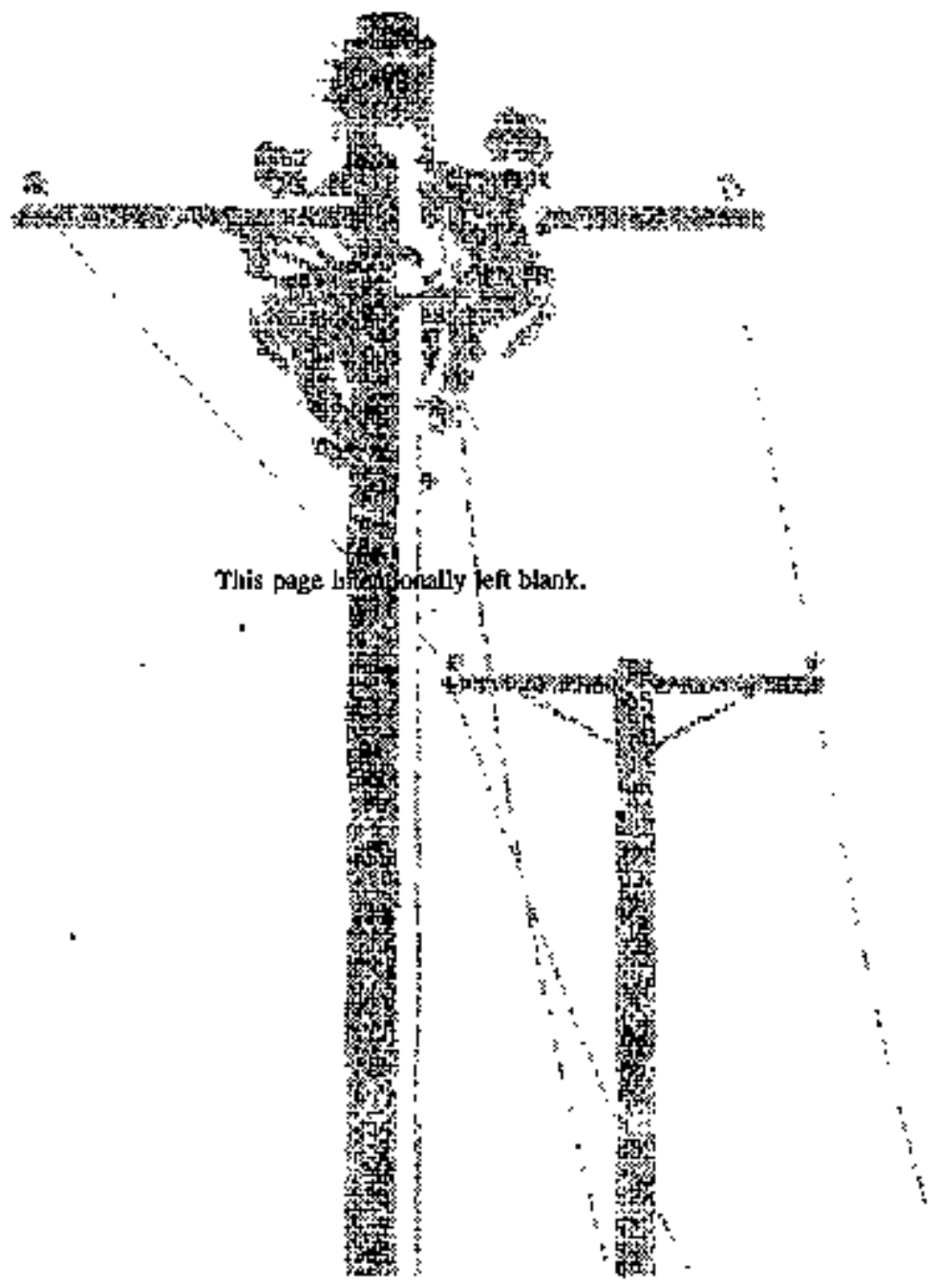




\section{HANF DRD TRANSMISSIDN}

AND

DISTRIEUTION SYSTEM

$100 \mathrm{~K}$
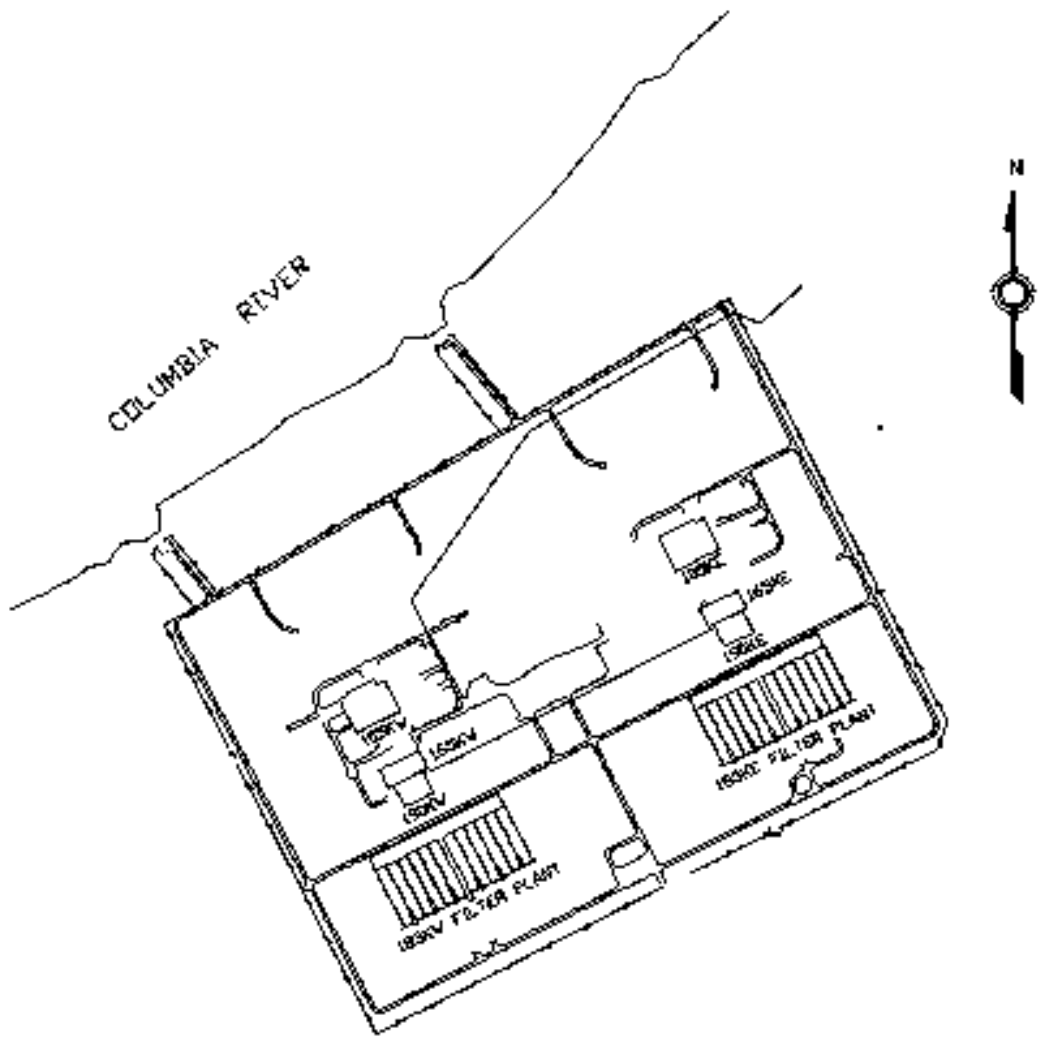


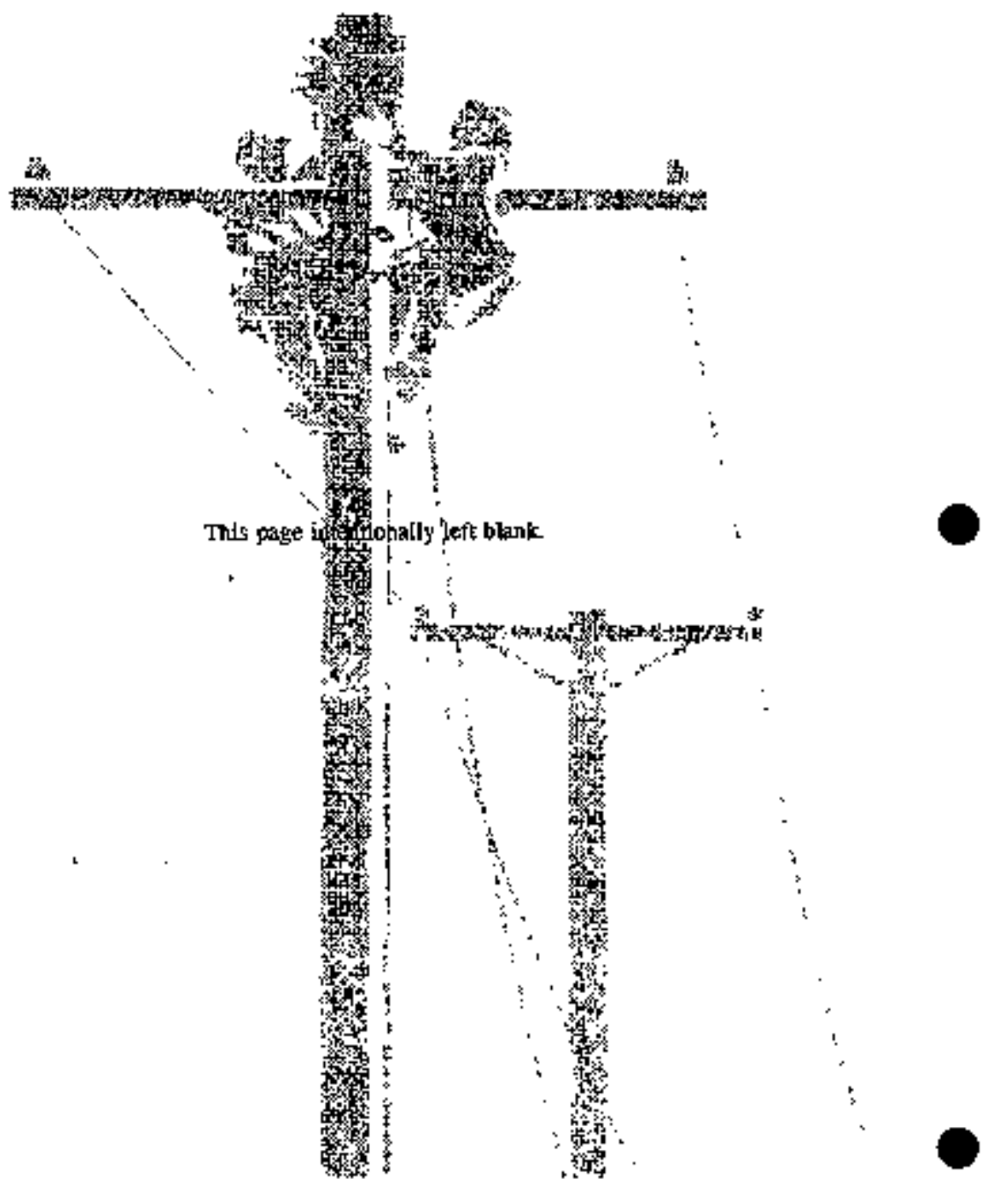




\section{HANFCRD TRANSMISSIDN \\ AND \\ DISTRIEUTION SYSTEM \\ $100 \mathrm{~N}$}

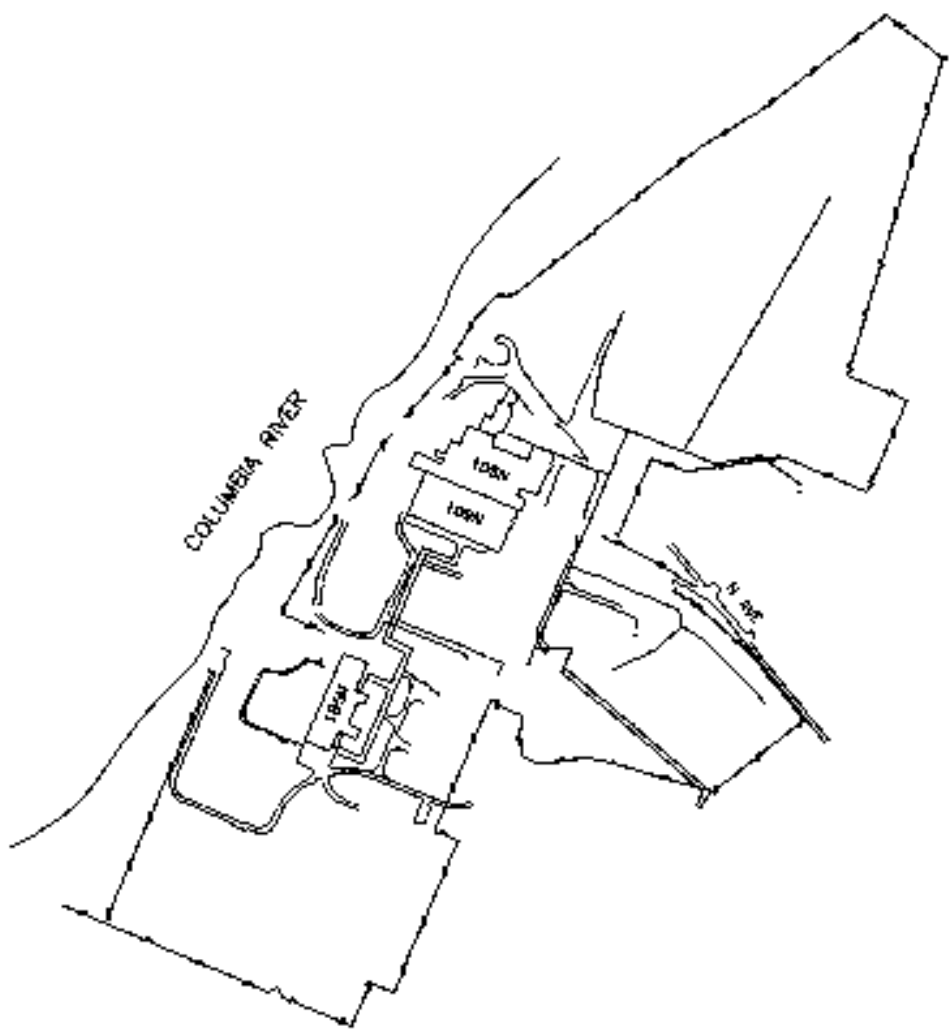

Fig. 5-5 


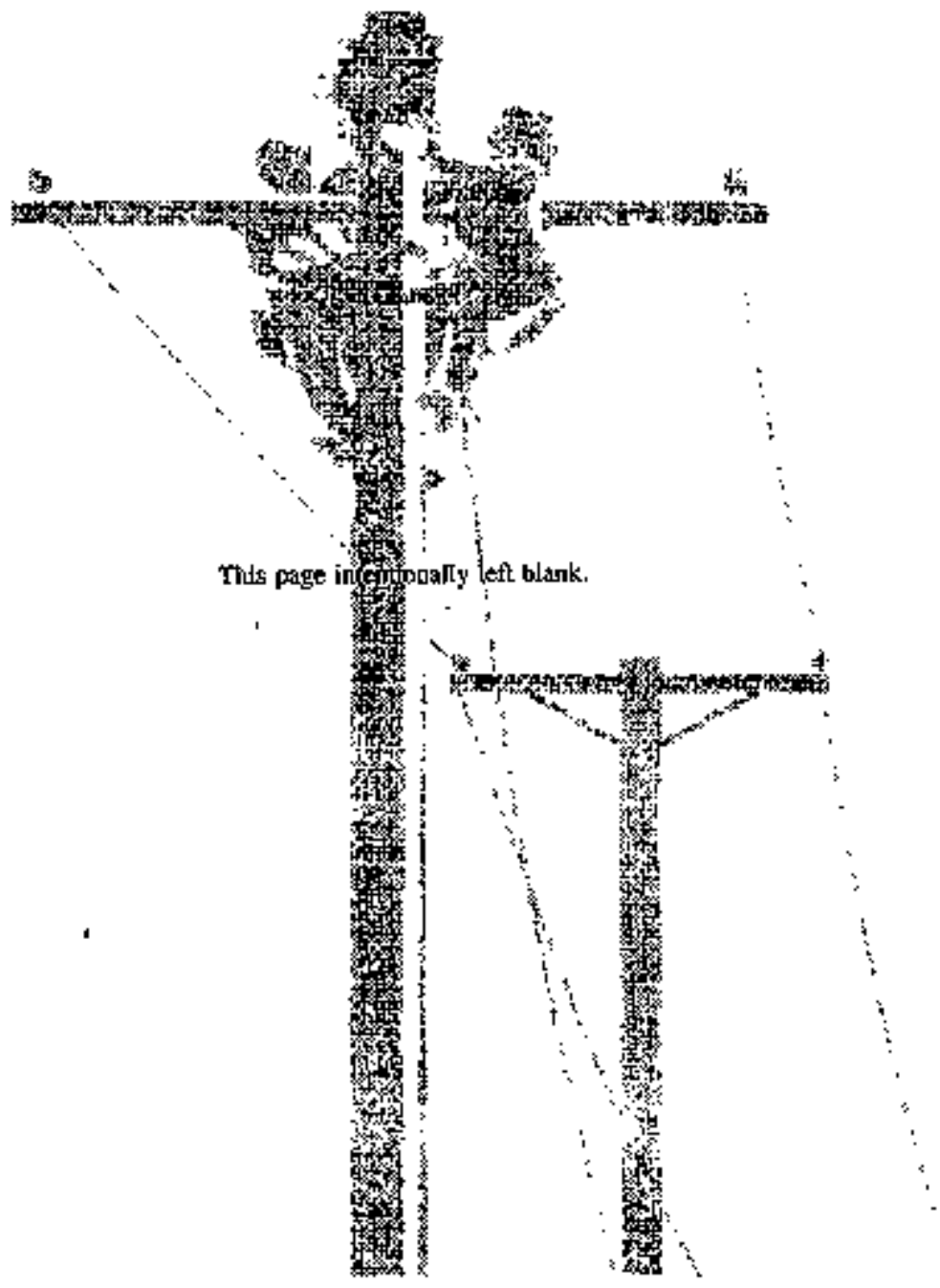




\section{HANFORD TRANSMISSIDN AND \\ DISTRIBUTION SYSTEM \\ 200 EAST}

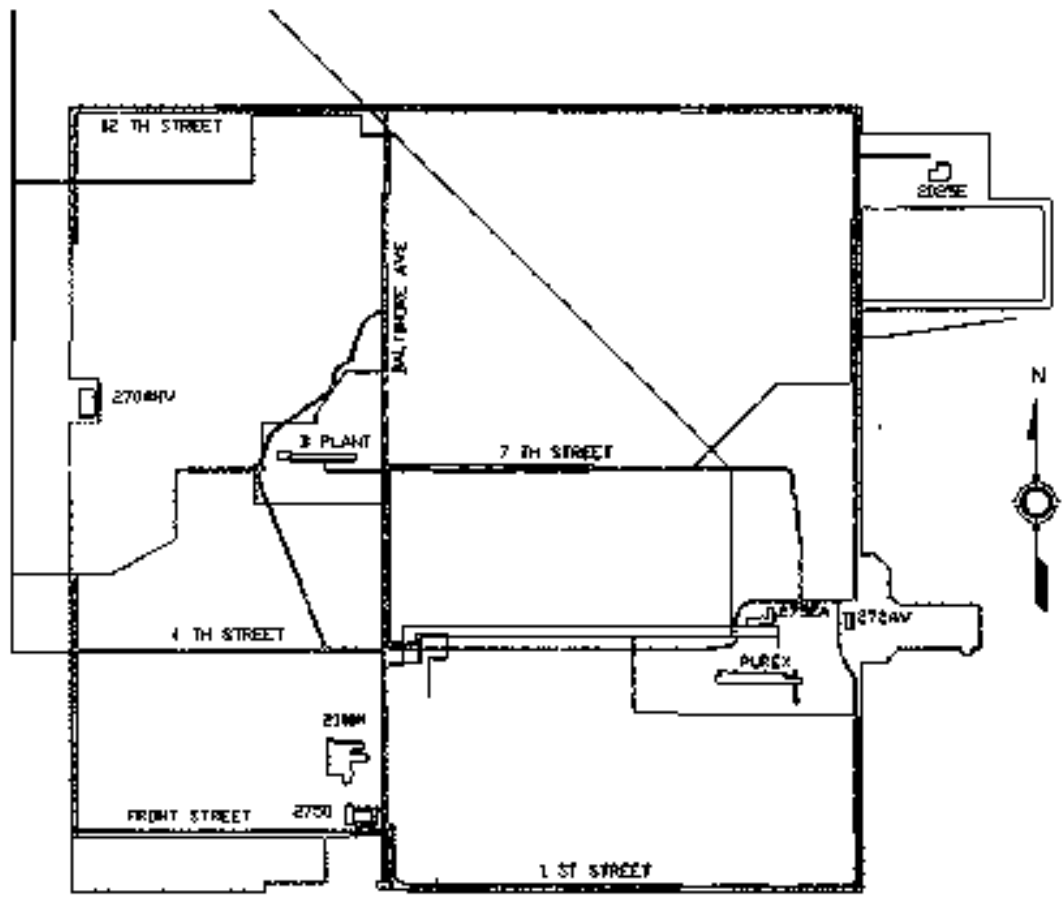

$2.4 \mathrm{KV}$ DISIRLEUTION LINES

6 nits

I3.3 KV DISTRIBUTION LTNES 26 mis

Fig. 5-6 


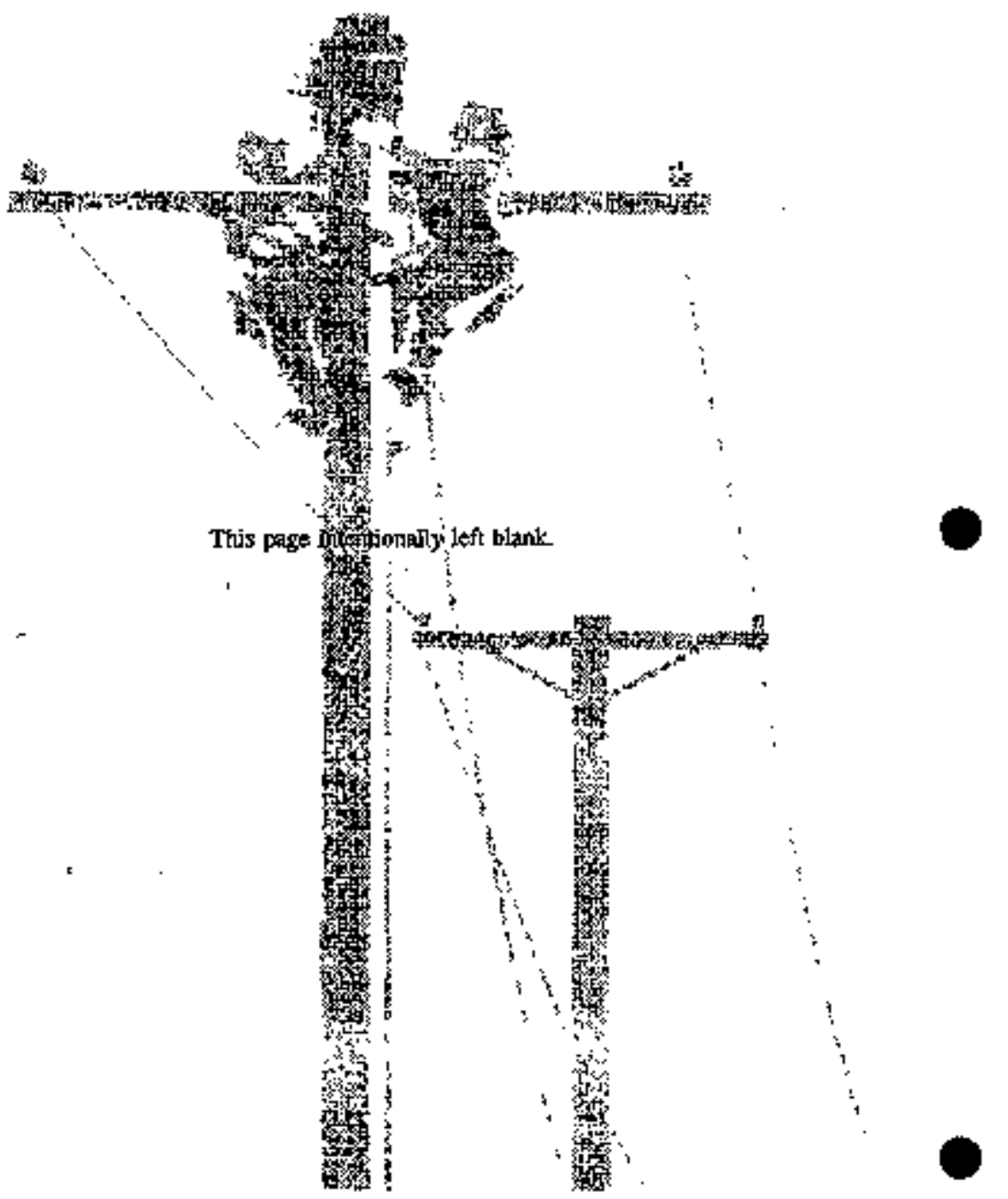




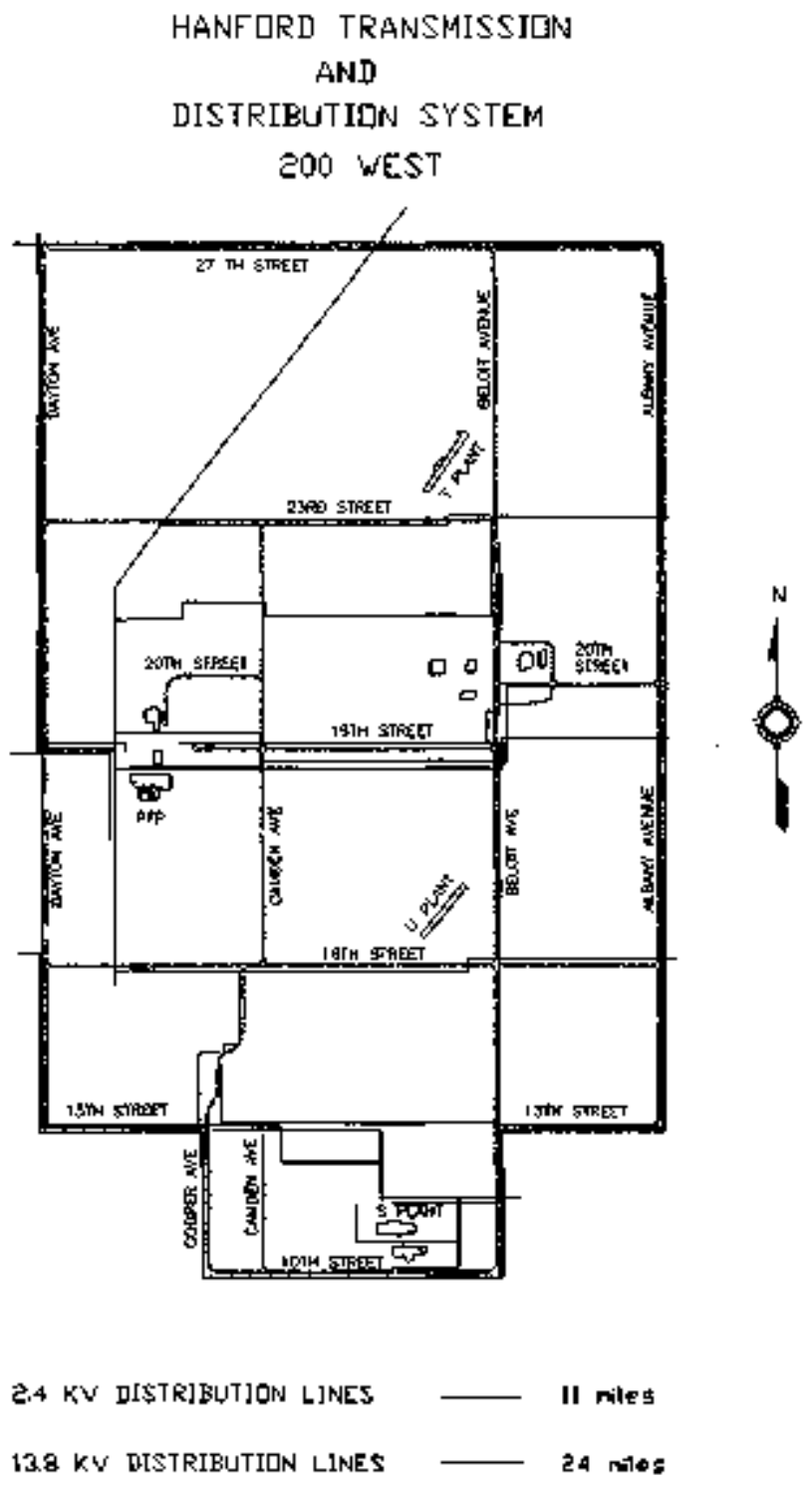

Fig. 5-7 


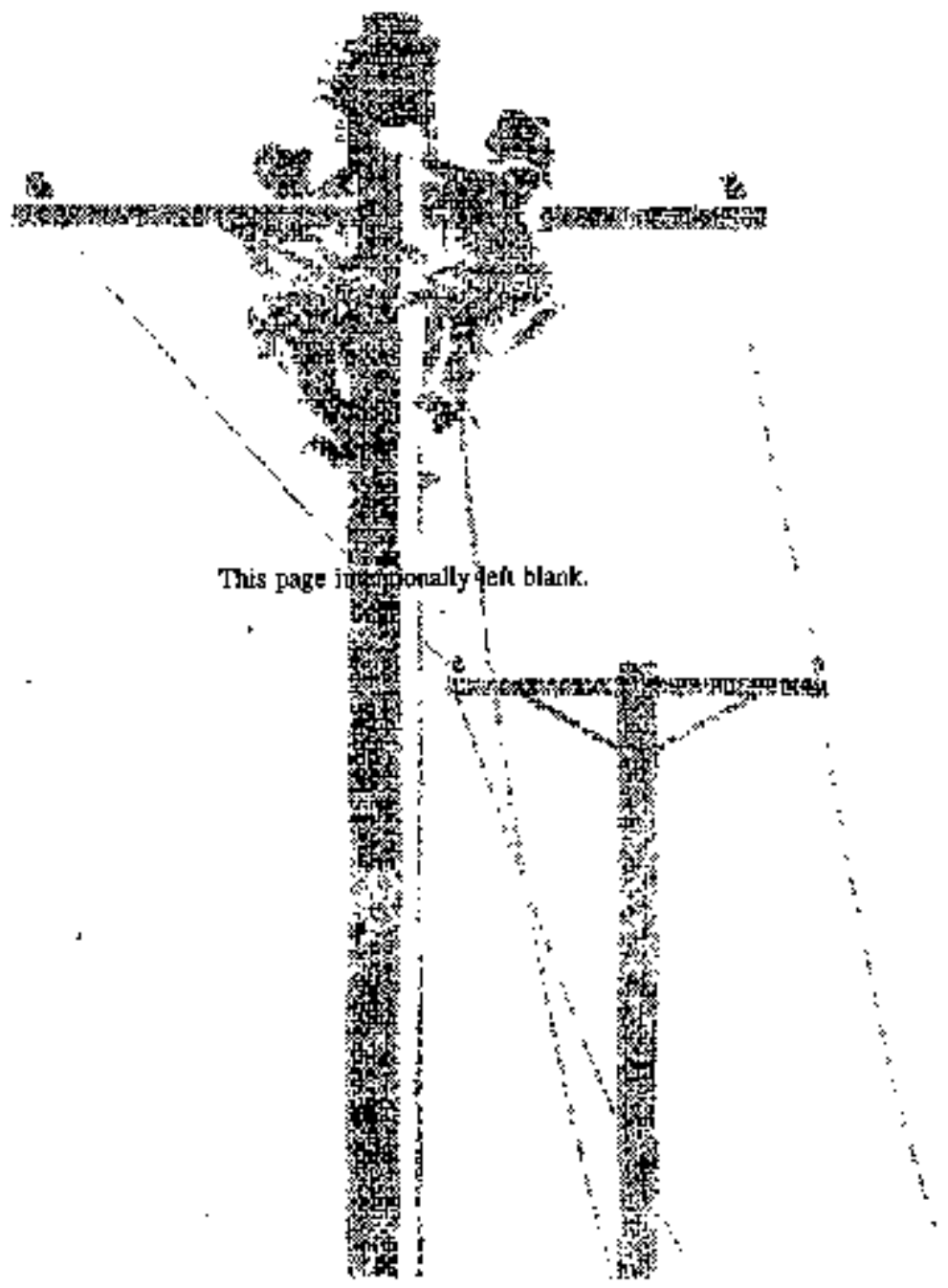


TABLE 5-1

100/200 AREAS CAPACITY

\begin{tabular}{|c|c|c|c|c|c|}
\hline Anea & $\begin{array}{c}\text { MVA } \\
\text { Installed } \\
\text { Coppeity }\end{array}$ & $\begin{array}{l}\text { MVA Uspale } \\
\text { Capaciry }\end{array}$ & $\begin{array}{l}\text { MW' Џłable } \\
\text { Capacity }\end{array}$ & $\begin{array}{c}\text { MW Peak } \\
\text { Demand }\end{array}$ & $\begin{array}{c}\text { MW } \\
\text { Available } \\
\text { Capacity }\end{array}$ \\
\hline $100-B$ & 62.5 & 31.25 & 25.0 & 2.8 & 22.2 \\
\hline 100-D & 31.25 & 31.25 & 25.0 & 4.2 & 20.8 \\
\hline $100-K E$ & 31.25 & 31.25 & 25.0 & 3.2 & 21.8 \\
\hline $100-\mathrm{kW}$ & 100.0 & 50.0 & 40.0 & 3.7 & 36.3 \\
\hline $100-N$ & 50.0 & 50.0 & 40.0 & 0.0 & 40.0 \\
\hline 200-EW & 100.0 & 50.0 & 40.0 & 26.9 & 13.1 \\
\hline Total & 375.0 & 243.75 & 195.0 & 40.8 & 154.2 \\
\hline \multicolumn{4}{|c|}{ Coincidental Dermand } & 34.9 & \\
\hline
\end{tabular}

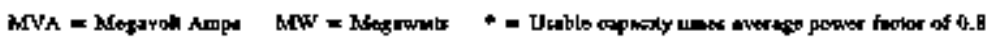

Syster capabilities in the 200 Ateas match preset deraand and expected erowth over the rext few years. As in the 100 Areas, the potrer deminds hawe diminished somewhat as the muclear fuel prosessing facilities move toward ghutdown. This is a pertod of kad transitton, with several platis going inco standby slatus while potentially tresmendous additional koads gre forcenst al clemoup facitities ire added.

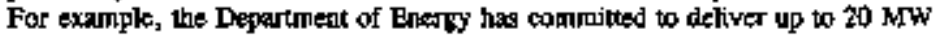
electrical pow at $13.8 \mathrm{~kW}$ for each of the two TWRS privatizalion factuties at each

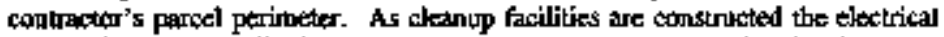
distribution systern will change to neet lhe new demand. Funding for these changes odganates from: each new faclity's construction budget.

5.2.4 Valles of Sygtem. The total cost of the IOO/200 Arcas detrical transintission and dispribution system (including aubstation buriliuns and equipment) is spproxiralakly $\$ 48,200,000$. This does not include buildings that heros utiliky personnel, service wehicles and equiprenth or spares inventory. The current reptacement cost of the system is estimated at $\$ 63,009,653$. The exlsting accounting system does not aegregate annually reocourting maintentance casts by service area. Area ntajulenance coses will becouthe availabse through the new work management syatem to be implemented duaing FY 1998, and the data will be used in subseryent Ievigions of this modd. 


\section{$5.3 \quad 400$ Arrag Syttam}

The 251-W substation, located in the $600 \mathrm{Area}$, serves as the Hanfond Site electrical dispateh center and housed the SCADA System. The \$CADA system monitors statis and atarms, and provides remove control to allow the dispatcher to thange electrical robtings through sever primary (six in 100/200 Areas and one in 300 Area) and four secondary substations (one in 200-E, ore in 200-W, and two in 300 Avea). As requested by eusteners and prograns, the 25l-W substation is operated on a 24-hour

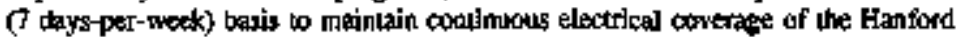
Site. The SCADA system is over 20 years ofd, uses obsolete technolosy, and is cartsenty being replacta with a new control system to allow foc effictent load

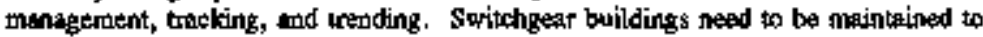
contínue safe opertation. Approxitrabely 49 miles of $230 \mathrm{kV}$ tronsmission lines, and 67 miles of $13.8 \mathrm{kV}$, and 1 mile of 2.4 distribution lines are located within the 600 Area.

The lotal cots of the 690 Area eilectrical trankmission and distribulion system (including substation buikdingt and equipurent) is approxinately $\$ 11,920,883$. The curtent replasement cost of the system is estimated at $\$ 23,687,425$. The existing

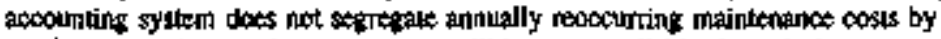
service area. Area maintenarca casts will become ayajlable through the new work manasemedl system to be implemented for FY 1998, and the data will be used in sutbsequent revisions of this moriel.

\subsection{Areas \$ystem}

5.4.1 Descotintion. The 300 Area electrical distribution system functions as the etectrical diatribution network for facilities located in the 300 Area on the Hanford Site. Electurical power is growided by two separate, BPA-owned $115 \mathrm{kV}$ transorission lineg: one from the BPA Bentor gubstation and the other from the BPA White Btulfs substation. These alternate source lines reduce the possibility of a complete power outage in the area and also allow for curouting power duriag mantenarke ouragets.

The primary systerd condists of one primary subseation containdth thee $115 \mathrm{kV}$ to $13.8 \mathrm{kV}$ step down trangformers providing normal power. The socontary distribution system includits tow sutostations, approxintakly 3.7 miles of $13.8 \mathrm{kV}$ aerial distribulion lines, an eatimated is miles of $13.8 \mathrm{kV}$ lines in urdenground ractwrys, and $0.2 \mathrm{~m}$ mes of $2.4 \mathrm{kV}$ distribution lines. ${ }^{12}$ Seven pricuary lines feed the 300 and 600 Area facilitics and one line extends as a backlp to the FFTF to prowide power for maintestance otlages. Two main swikching stations alow power to be provided from

IStandby power to designaled fapilitics is deflivered yia the $2.4 \mathrm{kV}$ distribution system. The aystem hes five diest peneraors capable of providing trackup power in the event of an oulage of the $13.8 \mathrm{kV}$ digtribution system. 
altemate feeds to provide for quick reskoration of service in the event of outages and for planted maimenance withoul internuption of service to facilities.

Ovtr 50 secondary switchún stations (distribution uansformers individually sized accorting to the beads beid serviced) support a tolal capacity of over $70,000 \mathrm{kVA}$.

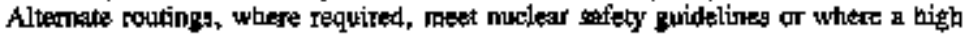
reliabllty for long-term experiments is needed.

Two major upgrade projects for the 300 Aren electrical distribution system werte completed in FY 1995. These projects, valued at $\mathbf{5 2 2}$ million, entanced persoonel safety and brought the tysten into commpliatex with the Nationel Electrical Safety Code. The $2.4 \mathrm{kV}$ noratal power lines and transformers were efirainated. Only the

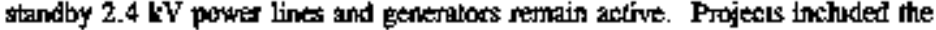
corversion of a dual woltage distribution systern to a single volkage system $(13.8 \mathrm{kV})$, relocaling power cables underground, replacing obsolete fence and steset lighting, downstzing transformers, and creating a duct bank system for future cable relocation. Exceptions wo the upgranks arte the 300 Area main (B3-S4) and 352-E (C3-3) substations $13.8 \mathrm{kV}$ switchgear which are expected to roguire replacemem in approximately eight yeors. The costs of these two switch systems has been estimated al \$2.6 milliog. Work on these two caplial profects is assutined to be stanted and completed during FY 2006s.

Figure 5.8 depiets the generall layoul of the 300 Area system.

5.4.2 Asqussment of Condilion. The 300 Area electrical distribution system is considered to be in very good condition, and has been rated as "good to excelledt for installattous of this type" by DOE-HQ consultants. Given norchal naintenance and

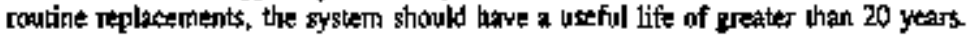
The main substation for the 360 Area has radioactive contanunaton beneath il. Althougb the contamination is stable, it will present tifficulty if and when excavation is required.

$5,4,3$ Capacity. The 300 Area e]ectrica[ 5ygtern bas two 20 matavolt-ampere (MVA) utanstotmers and obe 7.5 MVA teansformer for a usable capacity of $22.0 \mathrm{MW}$. The system thas a coincidental peak demand of $13.8 \mathrm{MW}$, thus keaving an available caparity of $8.2 \mathrm{MWW}$. Based upon demand and consumption, the $300 \mathrm{Area}$ transmissign and disuribution system, servine users in the 300 and 600 Areas, provides approximately 35 percent of the thectricity provided on-\$ile by the Electrical Utilities group. Table 5.2 provides a breakdown of the 300 Area capecity. 


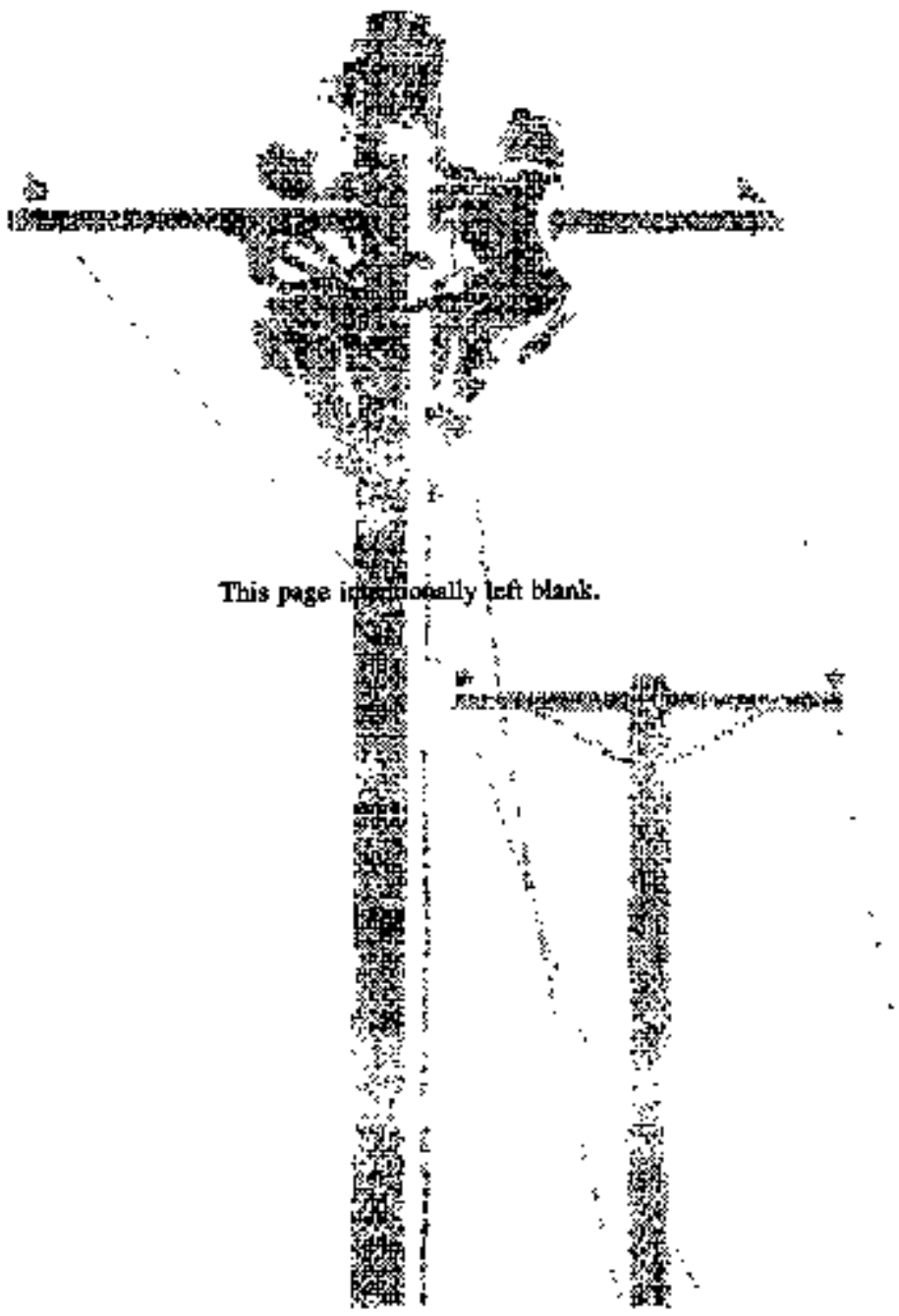




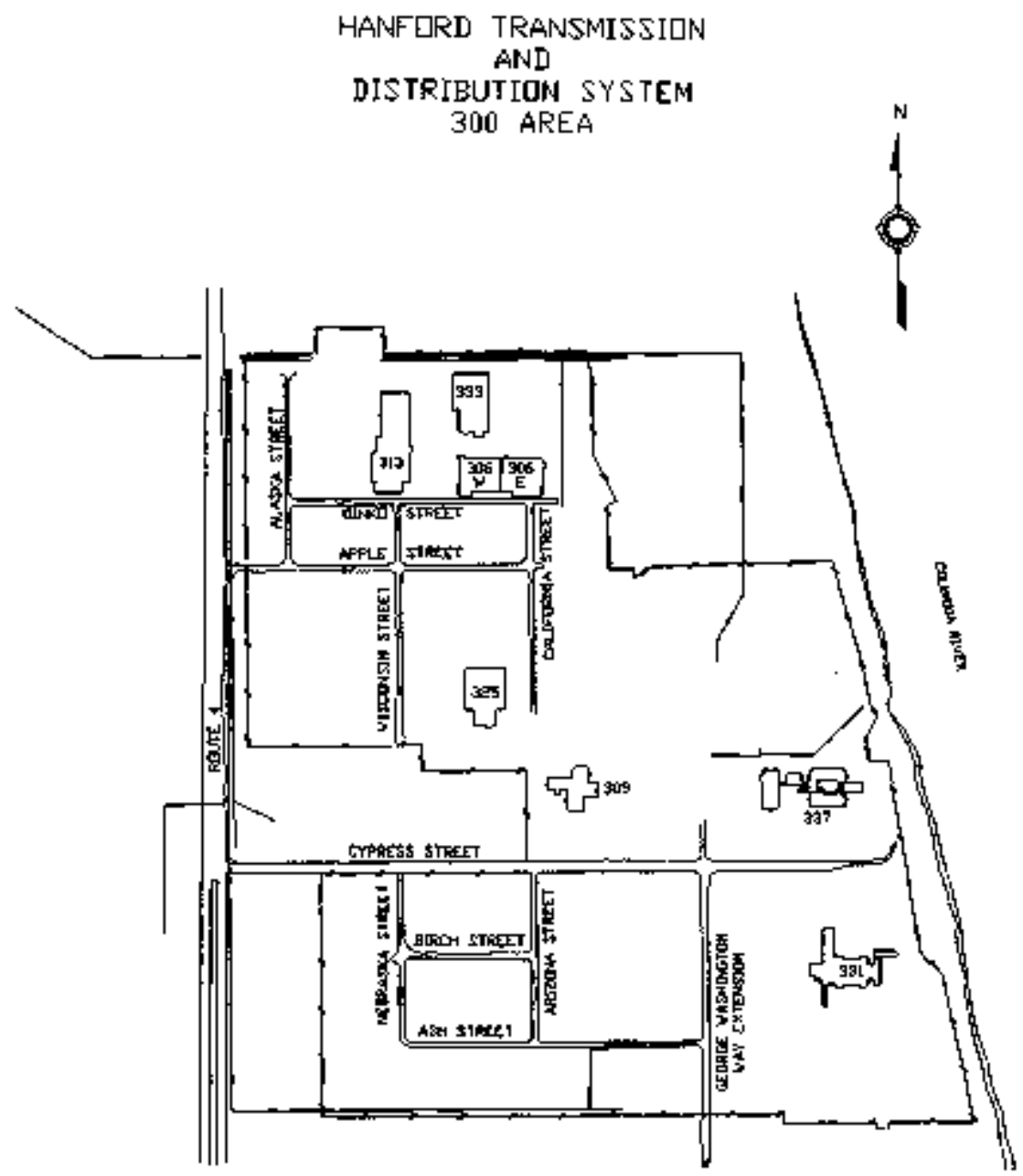

2.4 KV DISTRIBUTION LINES - D.e MTLES

13.9 KV DISTRIBUTIDN LINES - 3.7 MILES

Fig. 5-8 


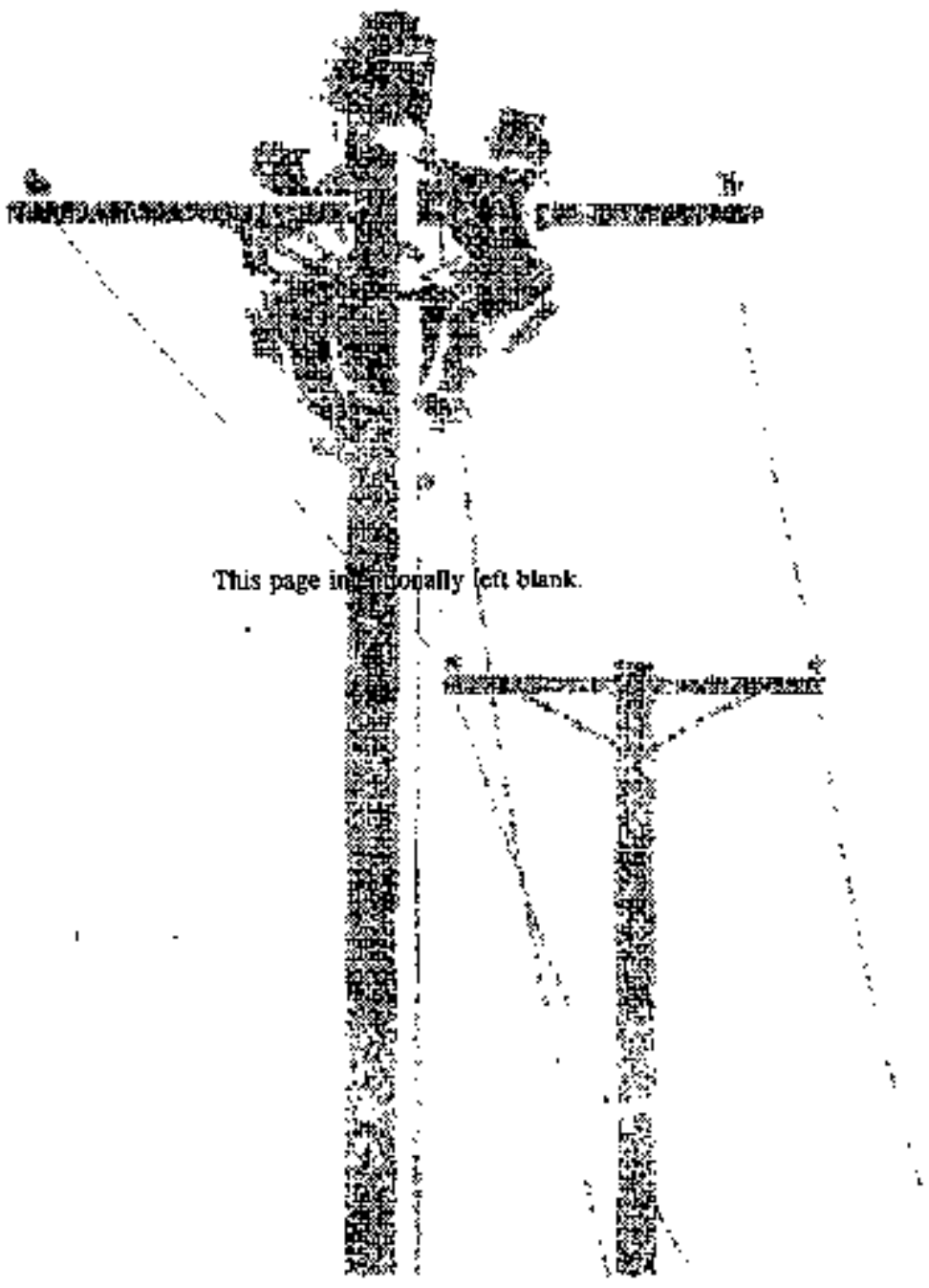


TABLE 5-2

300 AREA CAPACITY

\begin{tabular}{|c|c|c|c|c|c|}
\hline Transformitex & $\begin{array}{c}\text { MVA } \\
\text { Installed } \\
\text { Capacity }\end{array}$ & $\begin{array}{c}\text { MVA } \\
\text { Usable } \\
\text { Capacity }\end{array}$ & $\begin{array}{l}\text { MWr } \\
\text { IJsable } \\
\text { Capactly }\end{array}$ & $\begin{array}{l}\text { MW Peak } \\
\text { Demand }\end{array}$ & $\begin{array}{c}\text { MW } \\
\text { Available } \\
\text { Capacily }\end{array}$ \\
\hline 1 each, $115 \mathrm{kV}$ to $13.8 \mathrm{kv}$ & 7.5 & 7.5 & 6.0 & 0.0 & 8.0 \\
\hline $2 \operatorname{tach}, 115 \mathrm{kV}$ to $13.8 \mathrm{rV}$ & 40.0 & 20.0 & 16.0 & 13.8 & 2.2 \\
\hline Toul & 47.5 & 27.5 & 22.0 & 13.8 & 8.2 \\
\hline
\end{tabular}

S.4.4 Canotilities. Approximatedy 90 percent of the $300 \mathrm{Area}$ lood is currently melered. Roughly 75 percent of the kad is read automptically using FDAS. Currently, only $\mathbf{k}$ W bours actinally cocosumed are metered. Power factor metering is not requided due to power fackor contection being performed yla line capaciors.

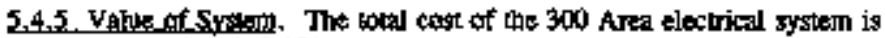
approxifrately $\$ 13,248,272$. The correat rephacenorat cost of the tystem is eglinatisd at $521,811,320$. The existing accomntixls system does nol segregate annoally recceurring maintenance costs by service ares. Ares maintenance costs will become available through the new work management systern to be iuplemented during FY 1998, and the dals will be tused in subsequen revisions of tris model.

\subsection{Artis}

5.5.1 Description. Primary electrical power to the $400 \mathrm{~A}$ tea is prowided by two 115 KV BPA transrisistion lines: one from the BPA Benton substation; and the second from the BPA While Bluffs substation. One $13.8 \mathrm{kV}$ the line from the $300 \mathrm{Area}$ to the 400 ATea power system prowldes altertate power for maintenance oulages, and a 3 MW pas lubink gencrutor is also available for temerrizency power. The distribution lines in the 400 Area electrical bystem are redundant to desigonated factilities to tosure continurity of service and rerouting of power for maintenance of system cordportents.

The FFIF facility is turntedy mainuained in a standloy capacisy until DOE determines whether or not the facility bal a role in the nation's ritingm propduction strategy. A decision is expecled by Decentber 1998, or carlitr. Should FFTF be rejected, the emergency tminine generator will be talken oul of service as soon as the soditum is

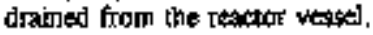

5.5.2 Astement of condition. The elactrical systems in the 400 Area are relatively thew. They were installed in 1980 through 1985 as part of the FFTF and Fueds and 
Materials Examination Facility (FMEF) construction projests. Considering the age of

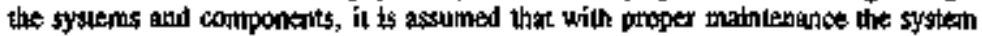
will have a useful life of at least amother 20 years. The uncertainty of future activity in the exigtias 400 Area facitities limits the options for the electrical transtuission and distribution systera.

5.5.3 Capacity. The 400 Arca contains two substations: $451-A$, which seryes the FPTF Reactor atd associated buildings. See Table 5-3.

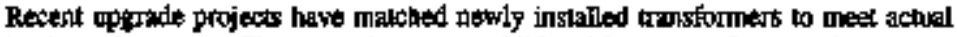

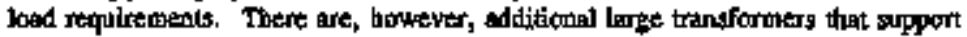
wery small loads and thereforo result in excessive energization losses. The approprlate timing neads to be determined for downsizing electrical systems as desclivalion of the facilities and areas propress.

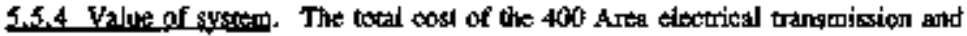
fistribution system (including substation buildings and equiprant) is approximakely $\$ 21,547$, $\$ 00$. The current replacernent cost of the system is estinated at $\$ 30,608,634$.

5.5.5 Maintenanke costs. The Electrieal Utilities group performs mambenance for

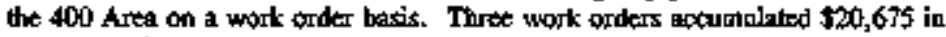
costs and 563,4 hours (0.44 FTE) through June 15, 1997.

TABLE 5-3

400 AREA CAPACDTY

\begin{tabular}{|c|c|c|c|c|c|}
\hline Substation & $\begin{array}{c}\text { MVA } \\
\text { Installed } \\
\text { Capacily }\end{array}$ & $\begin{array}{c}\text { MVA Usable } \\
\text { Capacity }\end{array}$ & $\begin{array}{l}\text { MW Usable } \\
\text { Capacily }\end{array}$ & $\begin{array}{l}\text { MW Poak } \\
\text { Demand }\end{array}$ & $\begin{array}{c}\text { MW } \\
\text { A vaiblable } \\
\text { Capacity }\end{array}$ \\
\hline 451-A & 50.0 & Generawors & 40,0 & $\$ .0$ & 32.0 \\
\hline $451-B$ & 66.6 & 33.3 & 26.6 & 4.1 & 22.5 \\
\hline Totel & 116.6 & 33.3 & 66.6 & 12.1 & 54.5 \\
\hline \multicolumn{3}{|c|}{ Coincidental Demand } & \multicolumn{3}{|c|}{12.0} \\
\hline MVA = & 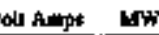 & - Mezowart & - Utablo teptery & au gutrape pones & teos of 0.8 \\
\hline
\end{tabular}




\subsection{Custoner Ekptelstions and Regniremants}

In somp service-oriented businesses, occapional busy signals, missed schedules, and cancellations are acceplable and tolerable. Power inkermuptions ane not. Electrical

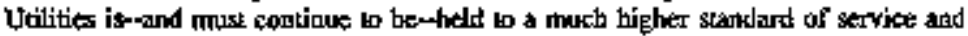
reliability. The service provided by Electrical tJilities is an essential ingrediemt in the success of the finford misslon. Customers expect accurate billing, low rates,

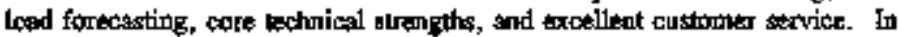
addition, many customers want service elements beyond dose which a utility routinely provides, such as oulasge coordination, 24-hour jispatch, and customer support services. Electrical Udbites personted have the capability to provike these services, which are directly funded by the faciitities.

The Hanfurd Site clectrical trantraistion and distribution systern, Aetigned and construcked to prowide an enhanced level of reliability, is ensential to Site cuatomerts and their ability bo andict Hanford nission speciffc actvilies. Babed on criteria sel by DOE Order 6430. IA, Electrical Utitibes maintain' a distribution system configeration which prowides altemate primary supplies for specifiest enitical facintites.

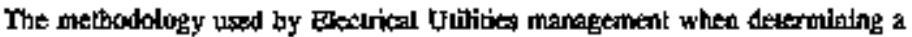
rroscoable kevel of service was a combination of regulatory drivers and all evailable information. In their abseace, "good bussiness practice" and a "cost effiective ure of the taxpayers' dollars" were applied. 


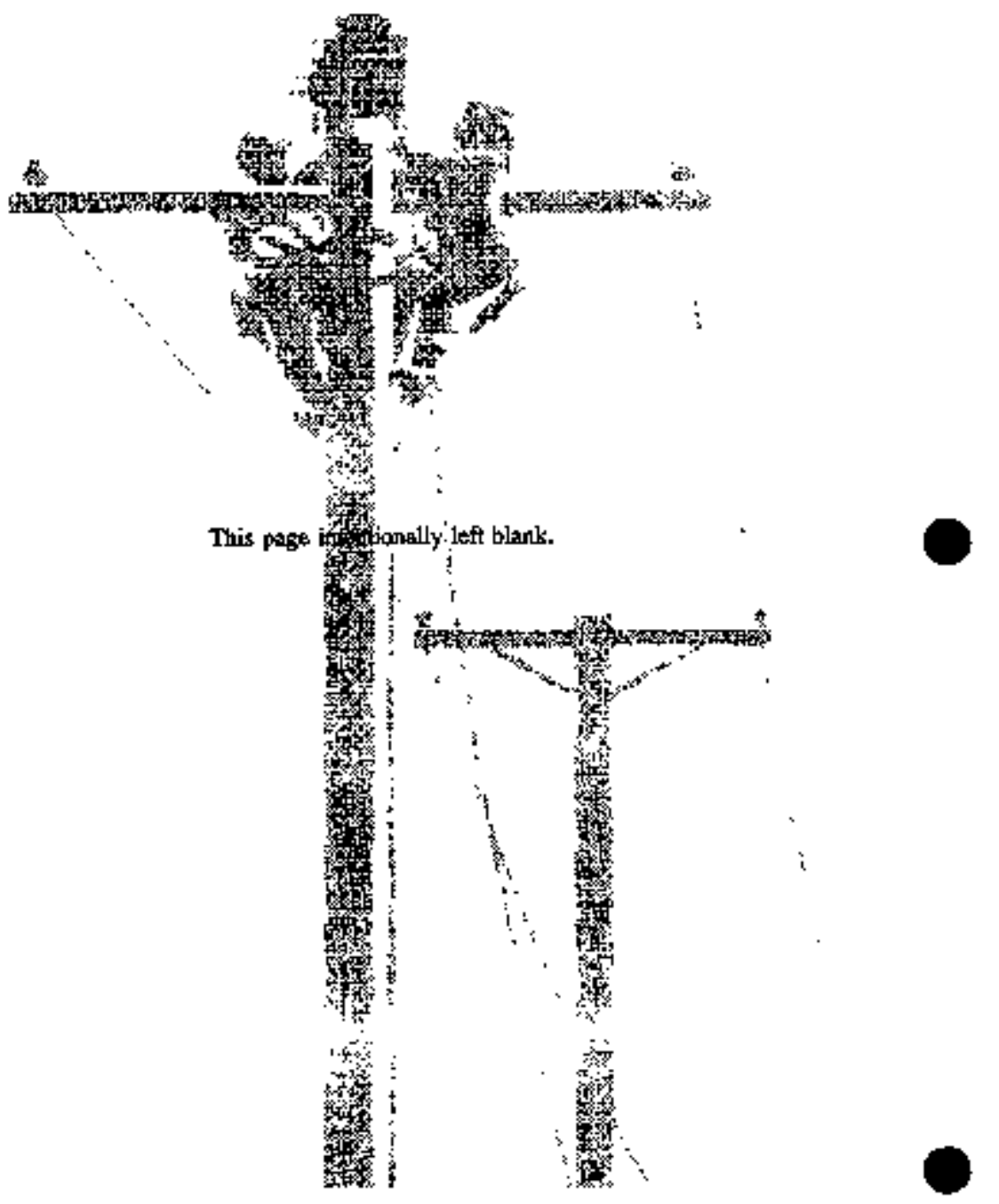




\subsection{ELBCTRICAL DISTRIIUTION CAFACITY AND FORECAST MODEL}

\subsection{Intwoduction}

The FY 1996 bwh consumption whe used as tha base year for capacily requirementh Exiztirg documeatation was used to develop a mpreadshect model forrocasting an anticipated leved of activity and eapacity required for the next len years. Past experifence has caused Electrical Utillles management to have varying levels of

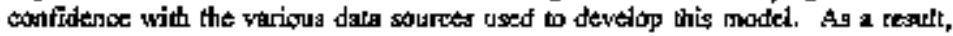

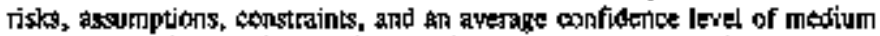
(probability of success) were tactored into the model. Table 6-I lists the varions data sources and confindence levels used.

TABLE 6-1

ELECTRICAL, DISTREIBUTION CAPACITY DATA SOURCE CONFIDENCE LEVEL

\begin{tabular}{|c|c|}
\hline Data Source & Confledence Level \\
\hline Cuptomer wark order requests. & Mepdium at start of year, high by mid-year \\
\hline Hantord Site Summary Schedule & $\begin{array}{l}\text { High for facility closure scherlule and } \\
\text { program completion, and identification of } \\
\text { new work }\end{array}$ \\
\hline $\begin{array}{l}\text { Site Support Program Plan'Multi-Year } \\
\text { Program Plan }\end{array}$ & Miedium \\
\hline Twenty-Year Power Forecast & $\begin{array}{l}\text { Medium as thew project loads are zenerally } \\
\text { jol known. }\end{array}$ \\
\hline $\begin{array}{l}\text { Inquirice and anticipated thetd dates by } \\
\text { program customers for new facility fonds } \\
\text { and remoyal of existing loads }\end{array}$ & Medium \\
\hline Avertige torfindence factor & Modiun \\
\hline
\end{tabular}

Alt charts in this section mode[ three cases (low, medium, and high-relate to

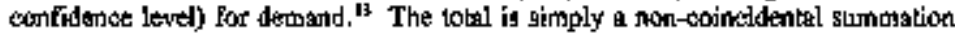
by area. The coincidental demand fectors applied to exch a्der are. 0.85 for the I00/200 Areas, 0.90 for the $300 \mathrm{Area}$, and 0.95 for tow $400 \mathrm{~A}$ Aren. The forecasted demand is for EPA electricity only (which constltules 97 percent of the total latid) and does not include the Ciry of Riehland or servicte Irom other utiliting.

ISinke the cherts for both demand and consumption ate adjite similar, only tbe demand charts have been included fim simplicjly. 


\subsection{Total Site}

Electricei needs are expected to gradually decrease over the aext tive years due to decontamination and decommdscioning activilies, despite new loads from clean up . aclivities. A aignificant increase is anticipated during the remainder of this ten year forecast perikd, primariky from Phases 1 and II of the TWRS privatization plants in the 200 Areas, and potential restart of FFT' in the 400 Aveat.

In suntinary, the 10 years power forcast showrs an overall increase due w the pritisty miseion change frorn production to cleanup and validates a continuing need to assure the feliable, safe and cost effective supply of electrical services to curlomers. Set Fig. 6-1.

\section{FY 19:6-2007 TOTAL SIE ELECTRICAL POWER FORECAST}

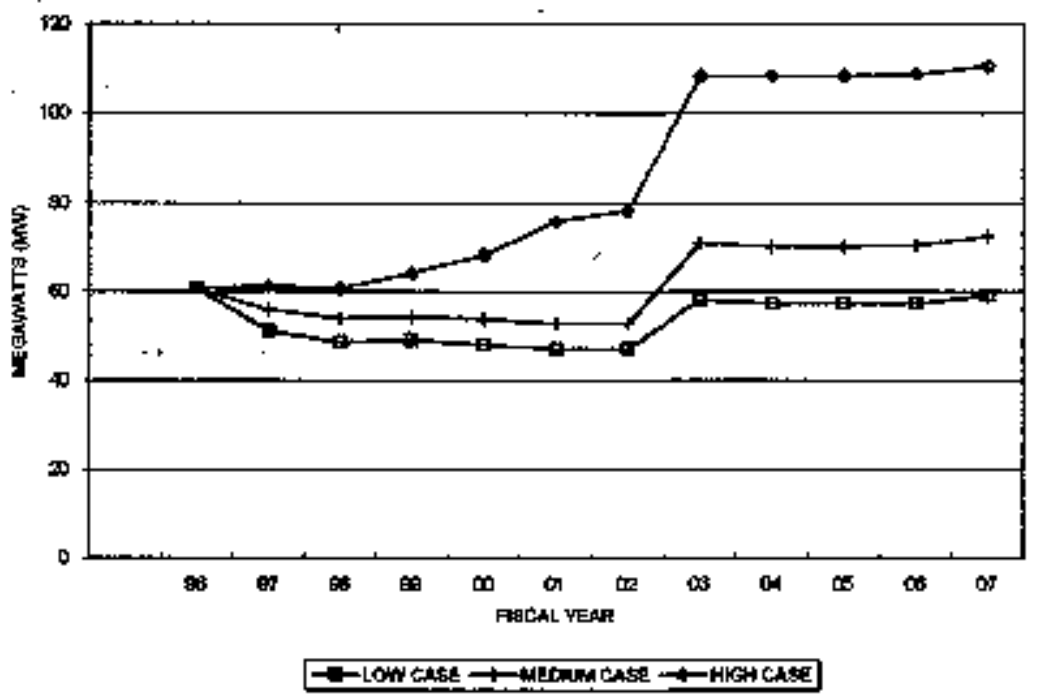

Flg. 8-1 


\section{$6.3 \quad 10002000$ areas}

The 100/200 Aneas electrical system 10 year power forecast stows an overall increase due to the primary micsion change from production to shutdown and cleanqp. While the pourer requirements in the 100 Areas are reduced, substential increases due to clean-up activltles are anticipated in the 200 Areas, with TWRS Fhase I and II the primary ugers. Capacily increases that are required for major new edectrical boads are provided by the programiproject that qenerates the need. See Fig. 6.2.

FY 1996-2007 1001200 AREAS ELECTRICAL POWER FORECAST

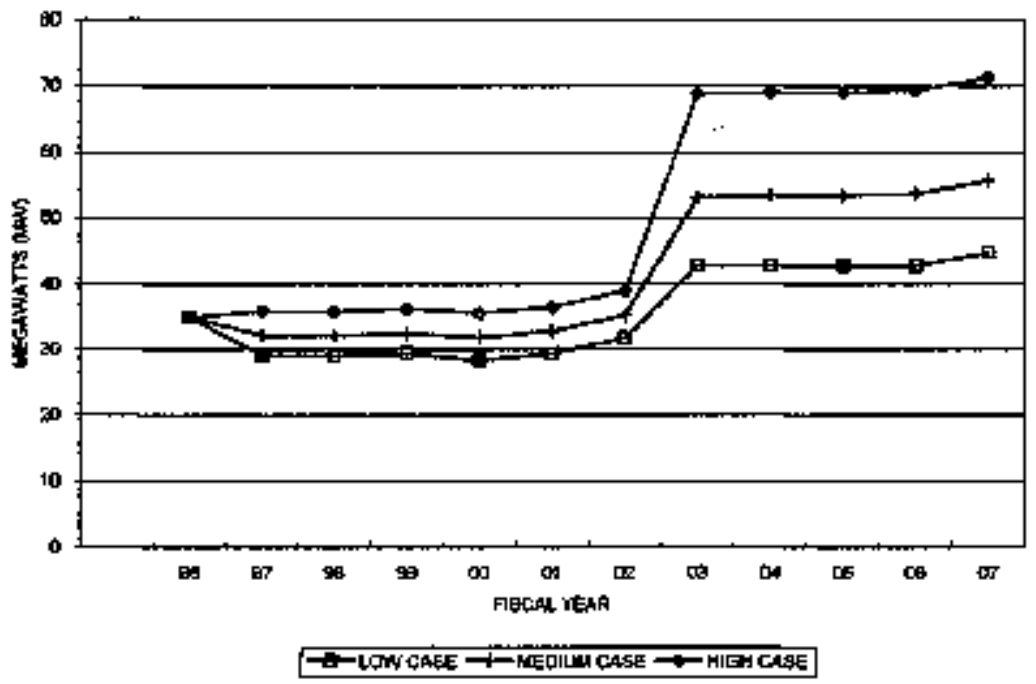

Fig. 6-2 


\subsection{Area}

The 300 Area electrical consumption is forecasted to remain fairly constanl over the mext 10 years. This forecast is for services currently fed frorn the existing $300 \mathrm{Aren}$ thistribution system. It does not take into consideralion demtand fitm the FWISL or HAMQMER tacilities, which art supplied by the City of Richland. Increases diven in part by the expected conversion from stom heal to electric heat in some facilities are offset by decontanination and decommissioning activities. Although some buildings are scheduled to be deactivated, econtumic transition activities may keep the electrical demand and consuraption at or near the present level. The 300 Area load is dwarfed in comparison to the loads anticipared in the 200 Artas. Ste Pig. 6-3.

FY 1996-2007 304 AREA ELECTRICAL POWER FORECAST

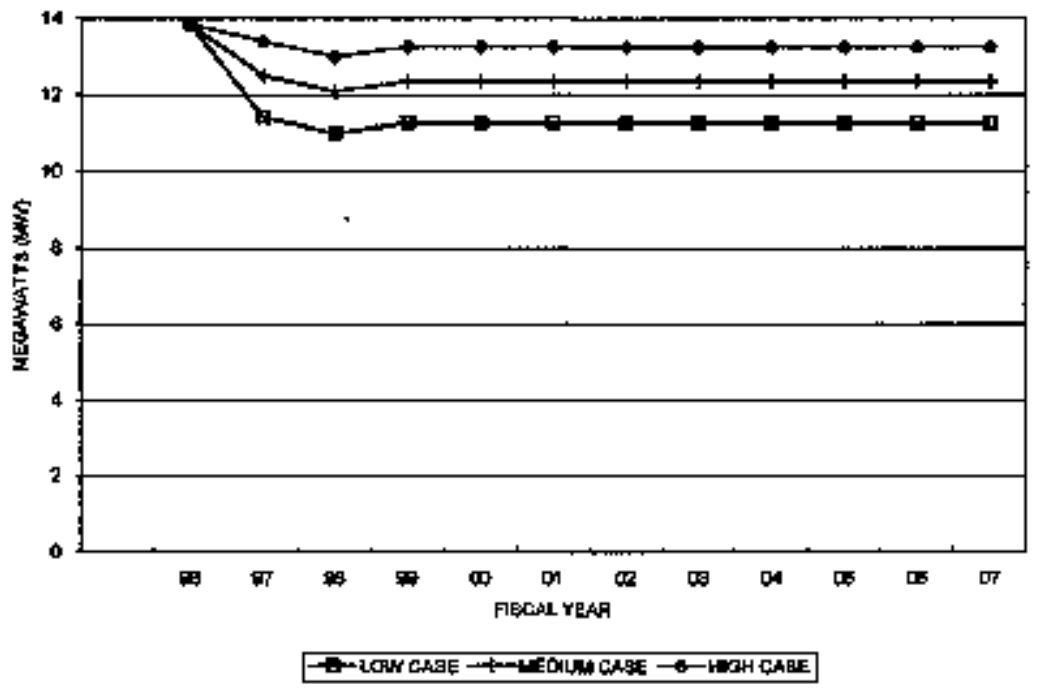

Fig, 6-3 


\subsection{Area}

The current standby operations of the 400 Area elecirieal system is a joint activily of FFTF Operations and FFTF Engineering with support provided by the Eloctrical Utilities trganization. This arrangement is expected to continte unti] December 1998 wher DOE delermines whether or not the facilily has a role in the netiog's tritium production stralegy. Ptriding DOE's dectigion, the 400 Alea forecast will show a decllne in power needs as the facilities trantition to shutdown and sodium remowal, or an increase as systerns are ro-energized. The forecast is only for BPA power and does not include pouser for the Laser Interferometer Gravilationtal Wave Observatory $(\mathcal{L O O})$ where it is assumed that the Bestion County Public Utility Disurist win supply pouver via the 451-B gubsiation. See Fig. 6-A.

FY 1996-2007 400 AREA ELECTRICAL POWER FORECAST

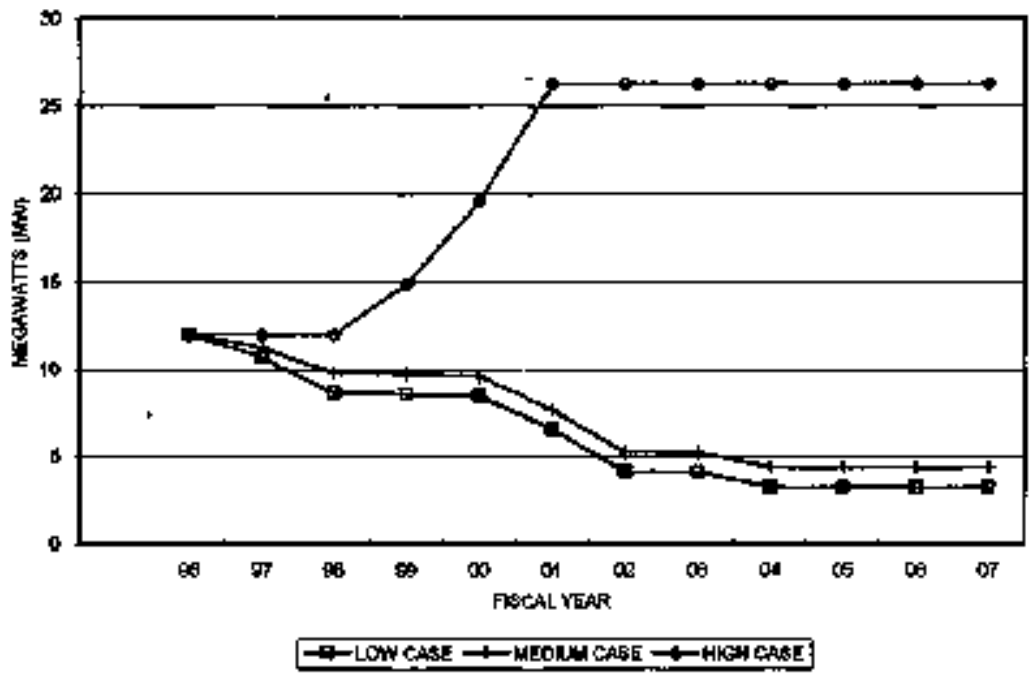

Fig. 8-4 


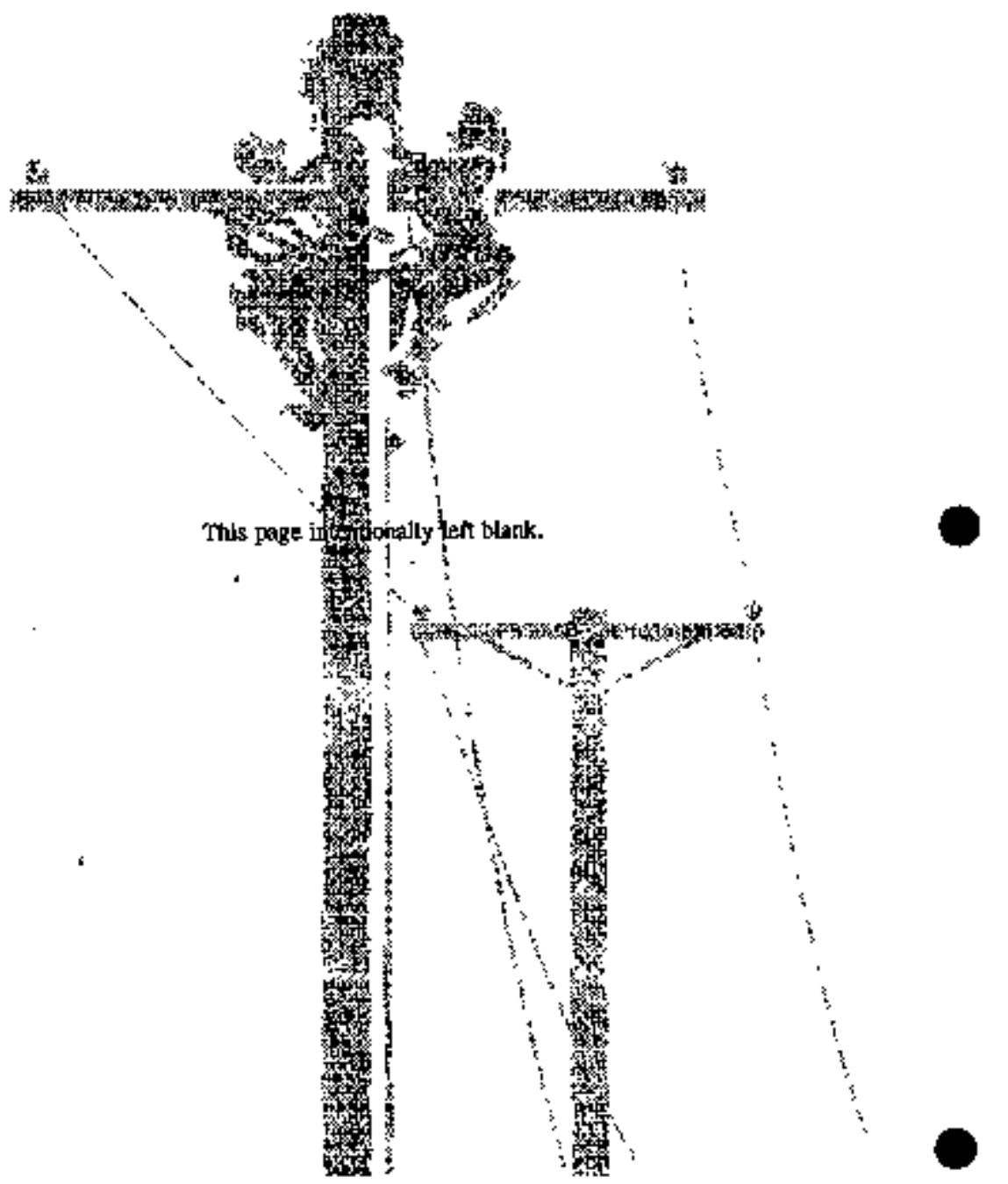




\subsection{FUNDING AND RESOURCE FRONECTION MODEL}

\subsection{Untrodpction}

The PY 1997 budget was used as the base year for furding and resolute requirentents. Fistorical experience, and estimates and obserwations of variables discussed in previous secikns of this document were veed develop a spreadshert

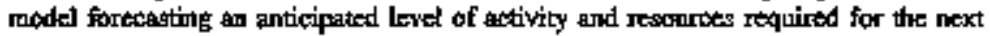
ten years.

Past expertince has cansed Eloctrical Utllities management is have varying kesels of confidence with the vartous data sources used to devekop this moded. As a tetult,

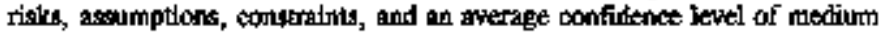
(probability of success) were factored into the radel. Table 7-1 lisis the cophidence lezvel of the various data sources used.

TABLE 7-1

PUNDING AND RESOURCE DATA SOURCE CONFIDENCE LEVEL

\begin{tabular}{|c|c|}
\hline Data Soance & Confidence Level \\
\hline Cuttomer twork order requests & Medium at start of year, high by mid-year \\
\hline Cost Account Plan & High for indirect labor and overhead \\
\hline Hanford Sile Summary Sctiedule & $\begin{array}{l}\text { High for facility closure schedule and } \\
\text { program compietion; and ideatification of } \\
\text { new work }\end{array}$ \\
\hline $\begin{array}{l}\text { Site Support Program PlaniMulti-Year } \\
\text { Program Plan }\end{array}$ & Mectium \\
\hline Elatrical Utilitic Forestast & Medhum \\
\hline $\begin{array}{l}\text { Requests by prigigram customess for new } \\
\text { facility loads and removal of existing loads }\end{array}$ & Matium \\
\hline Average confidence factor & Medium \\
\hline
\end{tabular}

The Electrical Uilities forecast inchudes:

- past wook practices

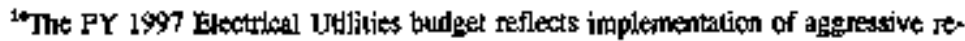
engitreering activities which significanty rechuced staffing and costs. 
- potential deactivation of substationg (with a corresponding decrease in backlor mainktepencte mot inftastructure)

- potentid etimination of redundant systems as hajzardout and rationctive facilities and contaninated areas are decontaminated and decomanisgioned

- reducing other infrastructure where no need exists

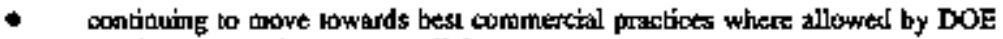
requirements and corripany policites

\subsection{Staflng Forecasts and Funding Regpirements}

An experianced otaft is the siogle most important factor in maintaining reliability. Regneltably, expenses may also be controlled with reduced staffing bevels. Howeyer, if Electrical Utilities is forced to make dexp staffing cuts, the ability to supply rehiabbe power to customers will be jeoprardized. Cumrently, Electrical Utilities is composed of 13.8 FTE bargtining unil, 18.3 FJE ekempt, and 3.0 FTE nonexempt persontel, or a ond of 35.1 FTE. ${ }^{5}$ An additional 10.3 FTE are direct fonded. No avditional FTE are requilred to met the demands of the projected work scope over the next ten years. \$te Table 7-2.

2.2.1 EY 1908. The following tristing and krownt potential projicats will not create any notictable increases or refuctions fromt existin

- economic transition nexts

- eight FY 1998 Landord Program Site Inffastructure projects within the cumenl taget funding leved

- Project W-500, TWRS Phase 1 Frivatralion Facilities

- completion and jaitial sart-up of Cantisker \$tracage Building comitplex

- furl temoval from $\mathbf{K}$ kasins and cold vacuut drying systems

- 300 Area Facilities and Sitt Servines Phase 3

- Liquid effloent facility enhancenent construction

- typiel Electrical Utilities operations and maintenance activities

${ }^{15}$ Full time equivalent figures which include 1.3 FTE exempt and 0.7 FTE bargaining unit Sapport from Oxhers. 
TABLE 7-2

FY 1997 FY 2007 EUDGETISTAFFING FORECAST

\begin{tabular}{|c|c|c|c|c|c|c|c|c|c|c|c|}
\hline FTE Detal & FY 1987 & fr 1908 & Fr 199s & EY 2000 & FY 2001 & fY 2002 & Fr 2003 & Fr 2004 & FY 2005 & FY 2006 & Fr200? \\
\hline Electrogal Utitin & & & & & & & & & & & \\
\hline Hon-Exentot & 30 & 30 & 30 & 2 비 & 29 & 29 & 26 & 28 & $2 \mathrm{~B}$ & 20 & 29 \\
\hline Total & 331 & 302 & 919 & 294 & 291 & 21 & ; 1 & 301 & 301 & 301 & 301 \\
\hline Begpost fiom Odhats & & & & & & & & & & & \\
\hline Exampd & 13. & 13 & 1 \$ & $1 \mathrm{a}$ & 13 & 53 & 13 & 13 & 13 & 13 & 43 \\
\hline Totol & 2 어 & 20 & 20 & 20 & 20 & 20 & 20 & 30 & 20 & 20 & 20 \\
\hline Tottal FIELeveis & F⿻t & 32 & 33.3 & 34 & 311 & 311 & $\$ 21$ & 321 & 321 & 321 & 321 \\
\hline 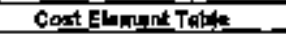 & FY 19:5 & FY 168 & FY 1898 & FY zasin & FY 2001 & Fr 2002 & FY SOA & FY F104 & Y 2001 & FY X006 & 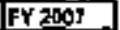 \\
\hline O lebor & 2,4068 & $2,502,2$ & 2,368 & 2377부 & 2,4141 & 2,4787 & $20 \% 2$ & 2,698 & 2,7722 & 2,8481 & 20240 \\
\hline 1 atadentis & 2133 & 2933 & 2133 & 103 of & 1930 & 1930 & 2933 & $2+3.3$ & 2139 & 2733 & 2133 \\
\hline suotolat Nat Butsot & 3.2500 & 3,233 a & $3,+2 \times 4$ & $3,0 \$ 06$ & $\$, 0757$ & 31404 & $3,358 \mathrm{~A}$ & 3.4297 & 3,6095 & 3,5702 & 3,6552 \\
\hline 4 Sild Sprinets & 573 ㅊ: & 505 日. & 5053 & 5482 & 54ध 2 & 5482 & 600 & 0068 & $800 \mathrm{a}$ & 608 日 & $\cos \theta$ \\
\hline 5. Indernel Chengag & 8152 & $\operatorname{sbg} 1$ & 8091 & 7322 & 3222 & 7322 & 8001 & 6201 & 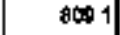 & $\sec 1$ & sol 1 \\
\hline a UABI SLPpont & 150 하 & t170 & $\$ 170$ & 105 o & $\operatorname{tas} 9$ & 1058 & 1170 & 117 计 & 1170 & 513 of & 1130 \\
\hline Jo DOH & 196 역 & 2911 & 291 & $26 \times 34$ & 2634 & 2834 & 2911 & 201 & 29: 1 & 2011 & 2811 \\
\hline Totol Euseting & 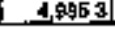 & Q.0EE 3 & 49524 & $4,6 \mathrm{eg}$ & $472 \div$ 여 & 4,7902 & 5,$10 ; 5$ & 62528 & 5.3724 & 5,4024 & 54783 \\
\hline
\end{tabular}

rollet

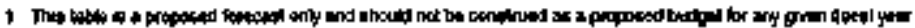

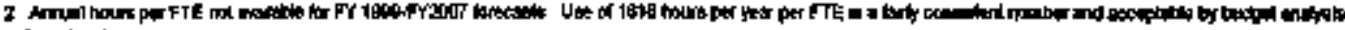

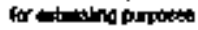

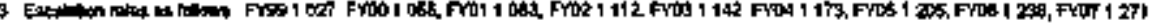

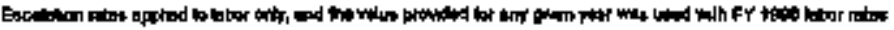

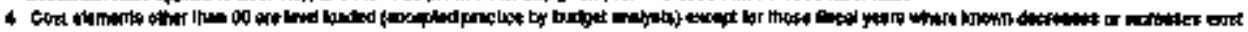

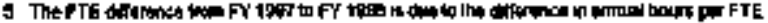


In January 1998, Electrical Utilities will submit to DOE-RI, layup plans and projected cous for 100-E, 100-KE, and 100-D substatlons. ${ }^{\text {to }}$ See Fig. 7-1. It is speculated that comtunents, subseguent revisions, and approwal to the layus pians may take until the end of FY 1998.

It ts premsture to futtelpate what impact lhe following will have on existing manhour requireorents:

- fud land use tecommentations under development by a jomt toderal, state, kocal, and tribsil planndig council, for effectipe use of astets no longer required by the fedetal povemnent (due Oetober 1997)

- pending decision by end of 1998 to restart FFTF or proceed with deacivation.

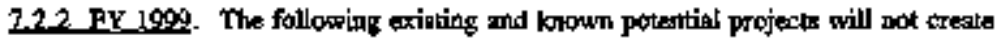
any noticeable increases or seshcthons from existing maphour rexuirenents:

- Project W-S03, TWRS Phase I PTivatization Facilitios

- fuet renoval from $\mathbf{K}$ Basins and cold vaculun drying syatems

- liquid effluenl facility enhancement construction

- B Plant deactivation support

- Building 324 eleantont and reartosal support

- typical Elestrictal Útilities tpperalions and maiatentarte activities

Substation deactivation activities for 100-B, 100-KE, and 100-D, if apposved, will probably oxcur during the furt six months, neductere FY 1999 operations and mainterance costs by $\$ 225,000$ and 1.6 FTE. Layup pians and projected costs fon the 252-E and 252-W substations will be subrilled in Jannary 1999. No impact o mathour requitements is anticipeted as it is thought that cormments, subsequent

\footnotetext{
${ }^{16}$ Currently, the $100-\mathrm{N}$ substation is not in service. A decision to resctivale the $100-\mathrm{N}$ substation is pending and will be taped upon 100 Arta coustomer tequirements regarding reliability ar availability of the electrical supply system. A request for information of cloctrical powrer requirements was transmitted on August 6, 1997,10100 Area customers with a response date of August 15, 1997. At of August 27, 1997, one response bas been naceived with two responses outstanding. Finalization of the future of the 100-N sobstation

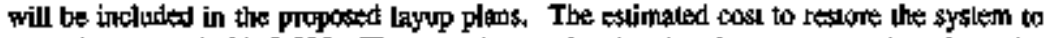
operation starus is $\$ 140,000$. The enruul operational and maintenance cost is estimated to be $\$ 70,000$ per year.
} 


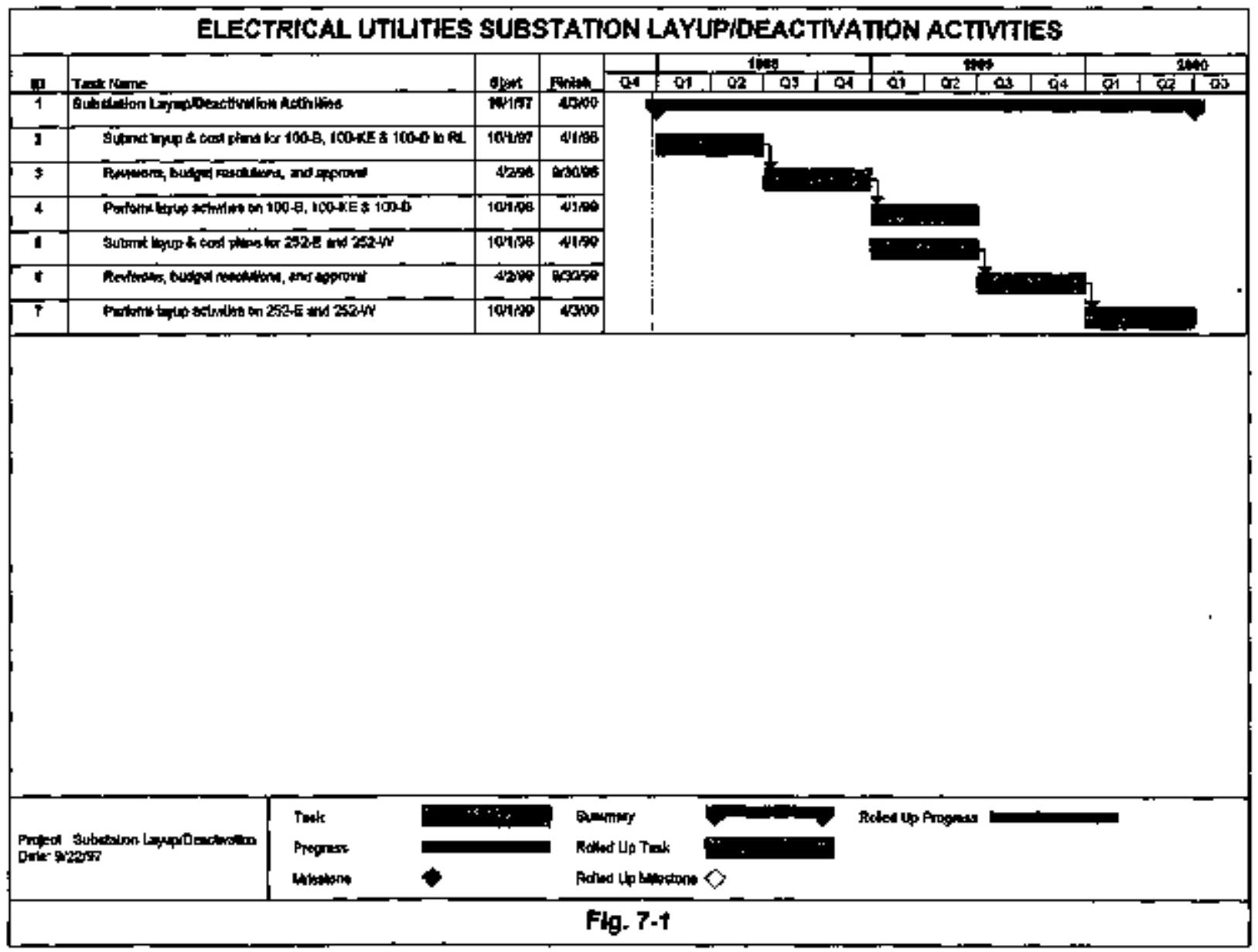


Ievisions, and approval to the layup ptans may take until the cord of FY 1999.

Likewise, the pending dectston by Dexember 1998 to resart FFTF or proceed with dopctivalion abould not noticeably impect requirements until FY 2000.

A forsibitity study to relocate the central dispatch station, if funded, will be conducted this riscal year.

7.2.3 FY 2002. The following existing and known potential projects will not create

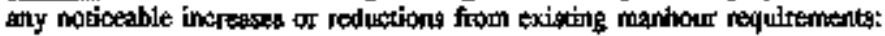

- Profect W-S03, TWRS Phase 1 Privarization Factlltes

- completion of fued removal from K Basios and cold vacuun drying systerts

- liquid tffloent facibity entlancemenl conskroction

Prior frecal year deactivalion of 100-B, 100-KE, and 100-D substations will reduce the FY 2000 openations and madrientimo budgex by an additional $\$ 225,000$ and 1.6 FTE.

Deactivating the 252-E and 252-W substations, if approved, stould occur during the

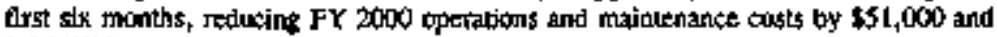
$0.36 \mathrm{FIE}$.

Fendiag the resulis of the feasibitity stody and approval of necessary furds, the central dispatch stathen may be relocaled this fiscal year.

2.2.4 FY 20.0L. The following existing and known potential projects will not create any noticeable increases or reductions from existing manhour requirearents.

- Profect W-503, TWRS Prase 1 Privarization Facilities

- completion of ligutd efluent facility entuancement

Prior tiscal year deactivation of 252-E and 252-W substations will reduce the FY 2001 operations and maintenance budget by an additional $\$ 51,000$ and 0.36 FTE.

No additional substation deactivalkm activities are forecast at this time.

2.2.5 PY 2002. The followiug existing and known potential projects will not create any noticeable increases or reduction日 from existing manhour moirements:

- Project W-503, TWRS Phate I Privalization Facilities

- $\quad 340$ facillty deactivation surpport 
typical Electrical Utilities operations and mainkarance activities

No stbogaliom deactivation activities are frocest al this time.

72.6 EX 2003. Typical Electrical Utilites operathons and maintenathe actlvities will nol require any increases from exigting manhour reqnirements. Completion of Project W-503, TWRS Phase I Privatization Facilities, may reguire addilional slafing. No substation deactivation activities are forderast at this time.

7.2.7_ EY,2004. Typical Electrical Utillies operations and mainterance activities will not requine any thereased from existing manbourt requirements. No substation deactivation activities are forecast at thts time.

22.8 EY 2005. The fotlowing tristing gnd krown potential projects will not create any noticeabile increases of reductions from existing manhour requirements:

- PFP deactivition support

- typical Electrical Utilities operations and naintenasce activithes

No substation deactivation activities are fọrecast al this time.

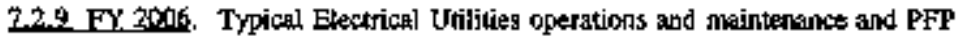
deactivalion support activilies will not roquire any butreases front existitg manthour requirements. However, a potertial declioe in deactivation and new cocostruction

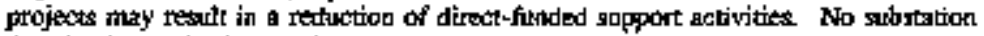
deactivation activitien are harecest al this time.

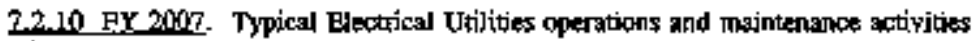
will not require any increases from existing manhour requinements. However, a poteatlal decline in deactivation and new construction projects may result in a reduction of direct-funded suppont activities.

7,3 Electrical Transmission aud Distribution System Upgrade Forectsis and Funding Recpirements

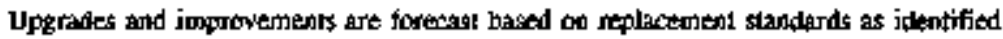
in reference documents, or equiponemt reliability without jecpardizing persontal and system protection activities. Maintaining the eloctrical transmistion and distributiont systerts is a coce iofrastrucure activity to meet dernand needs and assure reliable and coust effective systerits ate is place to met mission tequirements. Without upgrade and/gr Iepair, the condition of the system wiould degradk to the point of cotuiplete failure. Loss of electrical systems across the Hanford Site could cause substantial delays to the mission and impach sqlety requiroments. 
Downsizing the thectiral system when existing substations ard no longer cost effective o operate" will redpce energy losses with a cormesponding: (1) decrease in mainlenance and in[rastncluse activities; and (2) indease remaiming substalion capacity utilization.

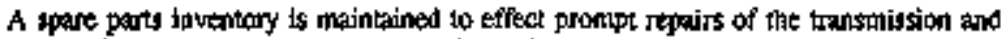
distribution systen. However, due to inconsistencies (matoufacturer, toodel, yesr) within he electrical componemt types throughoul the Site and coss, it is pot feasible to maintain a complete inventory of all transmission and distribotion rephocement equiputentL Whon nectsy, based on testing of requirements, kind-for-lind replacernents (expense or sapital fundes]) are requested to maintin safe facility conffigurations. Equipment in good condition which has not exceeded is useful life, which becomes avilable due to substation deactivations or facility shotdowns, will be reused in ling of new purchoses. Sable 7-3.

73.1 EY 1998. A communications recorder for the 251-W dispatch center and a

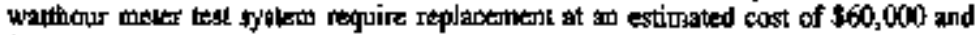
$\$ 25,000$ nespectively. Flectrowal transinission and distribution system capital upgrade requests sot approved and will be resubmitted for FY 1999.

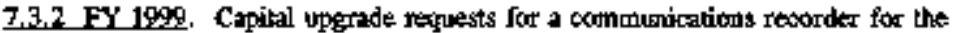

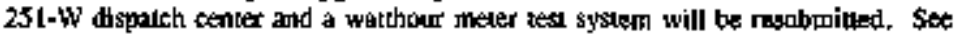
section 7.3.1.

Z3.3 EY 2002, Wo electrucal trantimission and distribution system capital upgrade requests arc timtagt

7,3,4 FY 2001. The 100-B, 100-D, and 100-K substalions will be bypassed following completion of layup attivities al an estimated cost of $\$ 4,500,000$. Relocation of the cencral electrical dispatch station is foresast at an estitnated cost of $\$ 500,000$.

7.3.5 FY 20022. Tho electrical transmission and distribution system capital upgrade requests are forectat.

2.3.6 FY 2003. The 251-W substation $230 \mathrm{KV}$ brealkers ant uransformers will require retrofit or replacement at an estimated obst of $\$ 10,040,000$.

2.3.7 EY 2004. The 100-KW substation $13.8 \mathrm{kV}$ swilchigear will fequitre netrofit or replacement at an estimated cost of $\$ 2,500,000$.

${ }^{I 7} \mathrm{U}_{p}$ [rous oil disposal and equipment excessing costs must be included in the life cycle cosh athalyzis. 


\section{TABLE $7-3$}

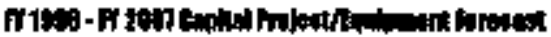

\begin{tabular}{|c|c|c|c|c|c|c|c|c|c|c|}
\hline & Fyise & FY 1Fo' & 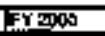 & FYanor & Frascas & 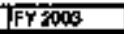 & FYaxoy & 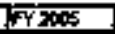 & Trसम & $7 \times 2007$ \\
\hline \multirow{2}{*}{\multicolumn{11}{|c|}{ 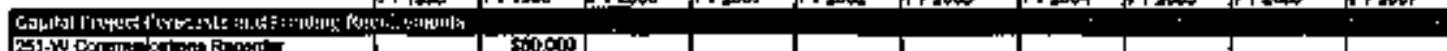 }} \\
\hline & & & & & & & & & & \\
\hline \multicolumn{11}{|l|}{ 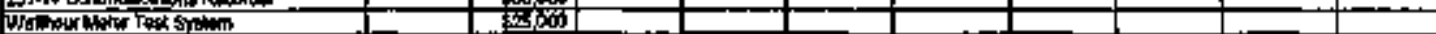 } \\
\hline \multicolumn{11}{|l|}{ 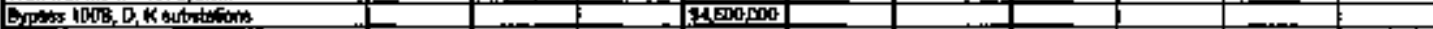 } \\
\hline \multirow{2}{*}{\multicolumn{11}{|c|}{ 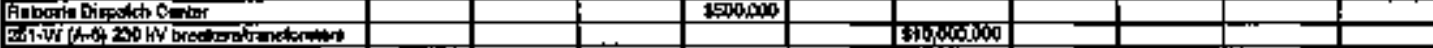 }} \\
\hline & & & & & & & & & & \\
\hline \multirow{2}{*}{\multicolumn{11}{|c|}{ 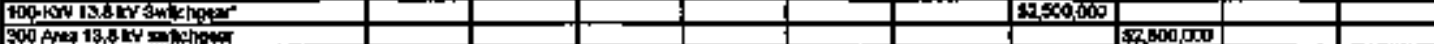 }} \\
\hline & & & & & & & & 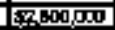 & & \\
\hline \multirow{3}{*}{\multicolumn{11}{|c|}{ 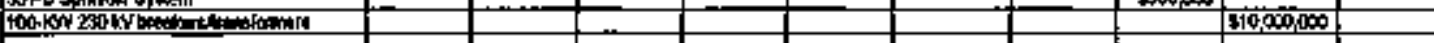 }} \\
\hline & & & & & & & & & & \\
\hline & & & & & & & & & & \\
\hline Ixt & bo & 500 & 电 & 5,0000000 & 포 & 13000000 & 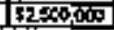 & ब不西 & 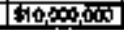 & $\underline{5}$ \\
\hline
\end{tabular}

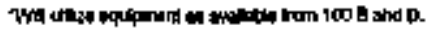

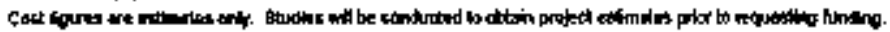

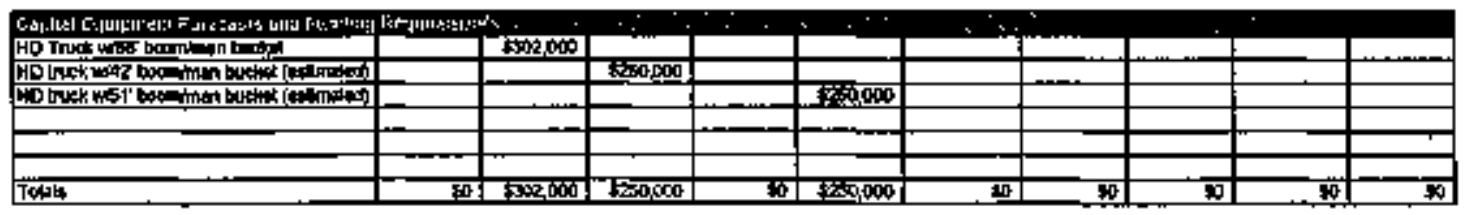

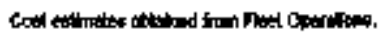




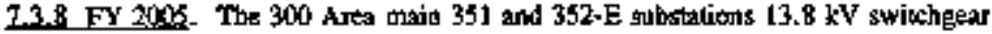
are expected to require replacentent al an estimated oost of $\$ 2,6$ million. ANother estimated $\$ \$ 00,000$ will be regitired to purchase and install an automalic sponkler protection system for the 351B substion porsuant to DOE Order 54(30.7A.

2.3.9_5Y 2006. The 100-KW substation $230 \mathrm{kV}$ breakers and transformers will requite retrofit on reglacement at an estimated $\operatorname{cost}$ of $510,000,000$.

7.3.10 PY 2007. No electrical transmission and distributton system capital upgrade requeds are forecast.

\subsection{Copltat Equlpment Forecasts and Fundog Reqwirements}

Electrical Utilities currently maintains an imventory of 53 vebicles, miscellareous small engines, portable boists, trailers, and other equiponent requited to meet transmission and distribution system and customker demands. "1 Most of the eqnipment is peculiar to Electrical Ulilities maintestance, and pone of equipntent cotsld be eliminated without inapacting the life cycle of the system or impacting the health and safery of employetes.

2.4. EY 1998. One heawy duty truck, equipped with a 65-fout telescoping boom and man bucleter essential for power lime maintentante, has exceeded both useful life (s) years 80,000 miles) and neplacement spondards identified in Code of Federd Regulations (CFR), Federti Property Managemenl Regolaticng, Snbchiplex o, Subpeart 101-25.4 and 101.38.9, "Replacement Standards." Capital equipment requests for FY 1998 were not approwed and will be resubmitred for FY 1999.

2A.2 EY 1090. One heswy duty truck, equipped with a 65-foot tolescoping boon and man bucker (see section 7.4.1). Totpl estimated cost for both the trock and man bucket is $\$ 302,000$.

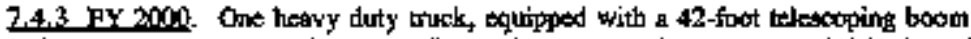
and man bucket essential for porwer line mainterambe, will have exceeded both useful life ( 9 years $\$ 0,000$ miles) and rep]acement skandards identified in Code of Federal Regulatious (CFR), Federal Property Management Regulations, Subchapter $G$. Subpart 101-25.4 ank1 101.38.9, "Replacenent Standardy." Total estimatod cost fọr botb the truck and man bucket is $\$ 250,000$.

24.5 FY 200I. No capilal equipment requeats are forecast

"Not included in this forsesst are sedans, pickops, and carryall toncks, which are Ieplaced by the General Serviced Administration (GSA) at the end of usefol bife. Also not inciluded are a mix of sinall mixkellaneons small engines and non-motorized equipment, which, given normal maintenance, should hawe a useful life of several more years. The implemkents are generally run-ko-failure and replaced as expense, oot capilal, inems. 
24.5 EY 20,02. Ore heavy duty truk, equipped with a 51-fook telesxoping borm and man bocket essential for power line maintenance, will have exceeded both useful He (9 years/80,000 miles) and replatement standards identified it Code of Feleral Requlations (CFR), Federal Property Management Regulations, Subchapter G, Subparn 101-25.4 and 101.38.9, "Replacercent Standards," Total estimated coat for both the truck and man bucket is $\$ 250,000$.

7,4,6 FY 2003. No capital equipment requests are forscast.

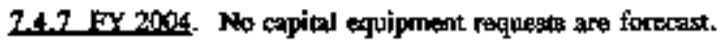

24.8 EY 200615. No capital equipment roquegts are fortcast.

24.9, FY 2006. No capilal expumpmitent requests are forecast.

7.4. 10 FY 20hy?. No capial equiproent requests are forecast. 


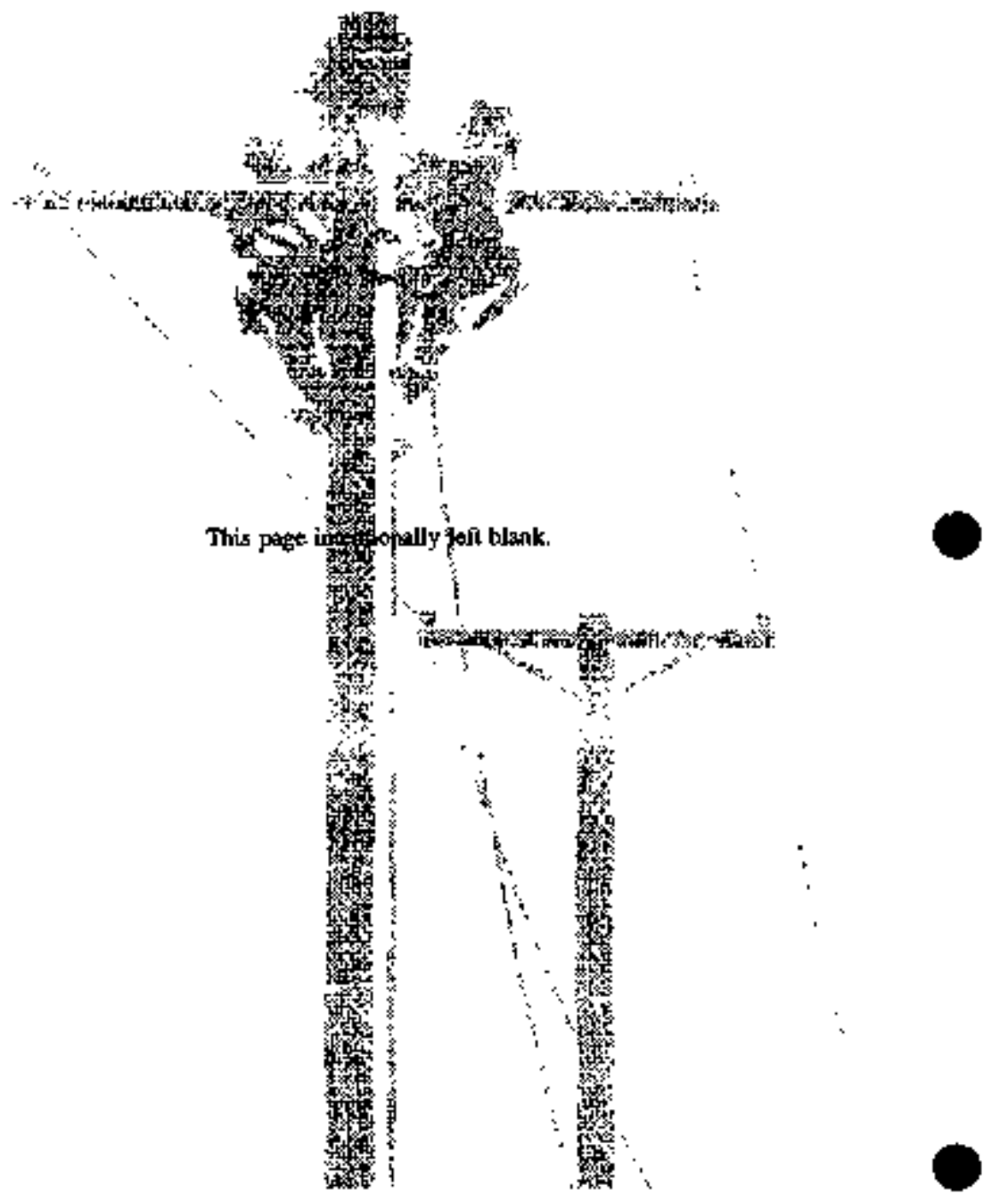




\section{APPENDEX A \\ REFERENCES}

BPA Notes, "Meeting with RRC redarding Delivery \$equent Charge, June 19, 1995.

Dohter, C. H., Life Cycle Strategies - 100/200 Aress, June 1995.

Dohver, C.. H., Life Cycle Stralogies - 300 Ares, June 1995.

Dother, C. H., Life Cycle Strateqies - 400 Arfa, June 1995.

Electrical Utilities (DynCorp), Analysis of Electrical Utilities Service, Reliablitity and Cosl Factor Relationathins, Desember 15, 1995 .

Electrical Utilties (DynCorp), Back op budget narrative for FY 1997 ADS, March 15, 1995.

Financial Dala System, reports FDSE 546w and FDSE 547W for Electrical Utilitied direct funded work order amounts from Oclober 1, 1996 though June 15, 1997.

Hanford Site Electrical Transomission and Dittribution Total and Replacednont Coos, Kathy Casey, DymCorp Asset Management, May 1997.

Hanford Sike Summary Schedule, Febroary 1997.

ICF Käser Hanford Cormpeny, $230 \mathrm{kV}$ and $13.8 \mathrm{kV}$ Electrical Confianralion withir 100 Areas, July 1995.

ICF Kaiser Hanford Company, Site Support Program Plan for ICPP Kneser Hanford Company. WHC-SP-[169, Rer, ], Augusl J996.

Infrastructure Transition Intiative Energy Tead Report, Feb. 1994

Landlard (DynCorp) Program Sila Infrastructure Project Priorities, FY 1998.

Ortz, D. I., Cosi Analygis ReportCity of Richland Proposal for 300 Area Utilities, May 2. 1996.

Prodect Hanford Management Contract, Part II, Section I, Appendix C.

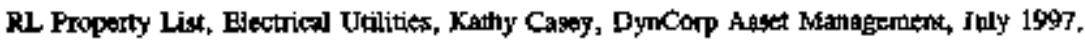

Rockwet! Fanford Opexattons, Long Range Work PJan and Backlog of Mainlenance and Repair Repent, FY 1985. 
SAlC, Handord 300 Area Electric Preliminary Vtility Options Study, Sept. 1995.

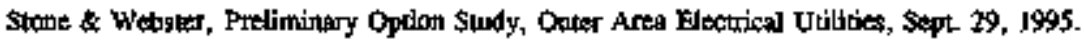

TECC Group, Inc, Littleton, Colorado, U.S. Electric LOU Toul Operation \& Matalezance Benchimart and Exponst Comparisions, 1995 (1996).

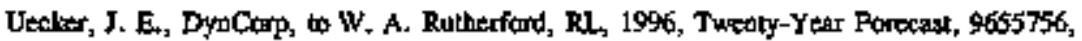
dated Now, 2\%, 1996.

U. S. Department of Energy, Hanford Site Infrastructure PJan 1989 (January 1990).

Vehicle Fleet Management System, Report VFM-2182-R, Equjpanemt List by Assipred Oreanization, data at of barech 29,199 ?

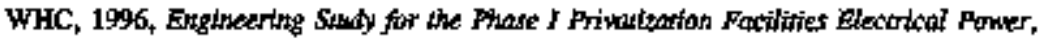
WHC-SD-WM-ES-393, Rey, 0, Westinghouse Hanford Company, Richland, Washington.

Numereus articles publisted in Thansonission and Distributon Wordd 


\section{APPENDIX $\mathrm{\theta}$}

\section{ELECTRICAL UTILITIES FY 1997 BUILDING BLOCKS}

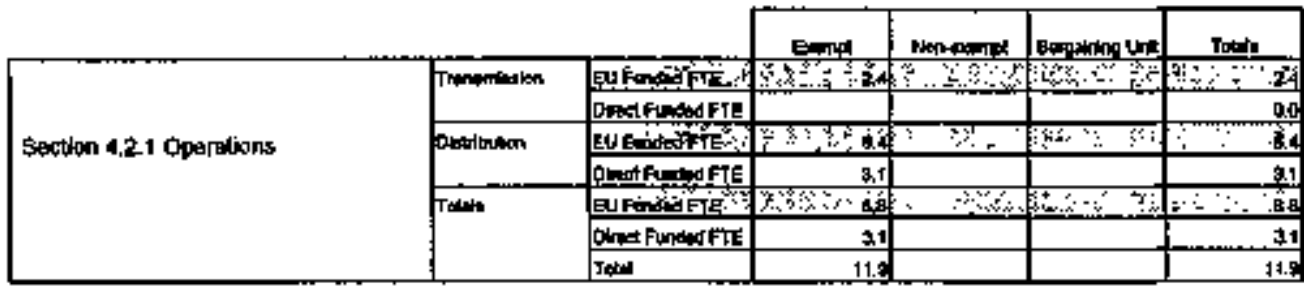

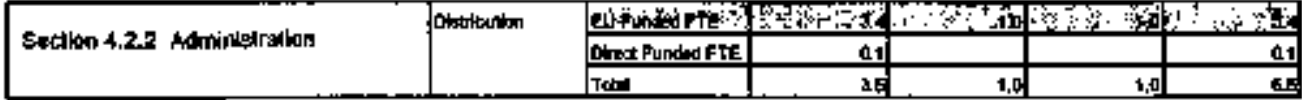

\begin{tabular}{|c|c|c|c|c|c|c|}
\hline \multirow{7}{*}{ 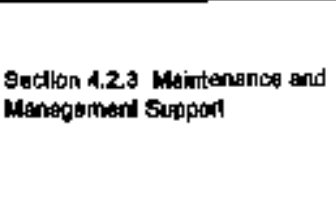 } & \multirow[t]{2}{*}{ Tanomiagion } & 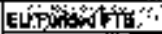 & Won & 5,800 & 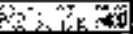 & 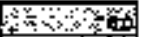 \\
\hline & & Cuwer Punded at & & & & 0.0 \\
\hline & \multirow[t]{2}{*}{ Okectiouthon } & 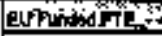 & 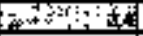 & $-\ldots \frac{1}{2} ;: 14$ & 영 & 글 \\
\hline & & Oinst Funder fIE & 1.2 & & 5.9 & 7. \\
\hline & \multirow[t]{3}{*}{ Tots } & Er pón & 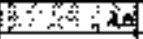 & 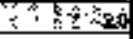 & 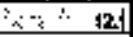 & 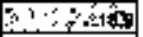 \\
\hline & & 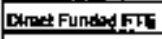 & 12 & 0.0 & 5.0 & 7.1 \\
\hline & & T어염 & tal & 20 & 180 & 혁 \\
\hline
\end{tabular}

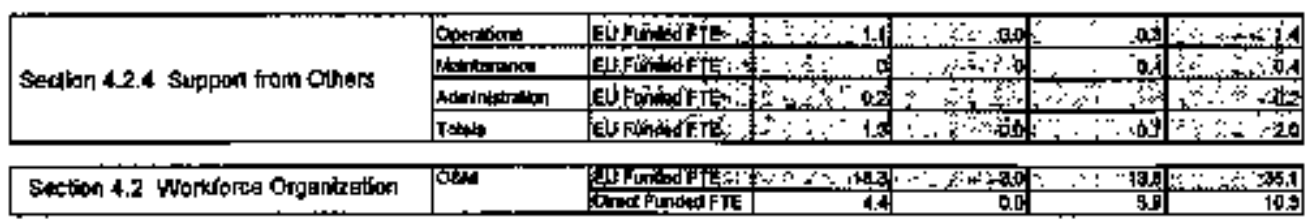




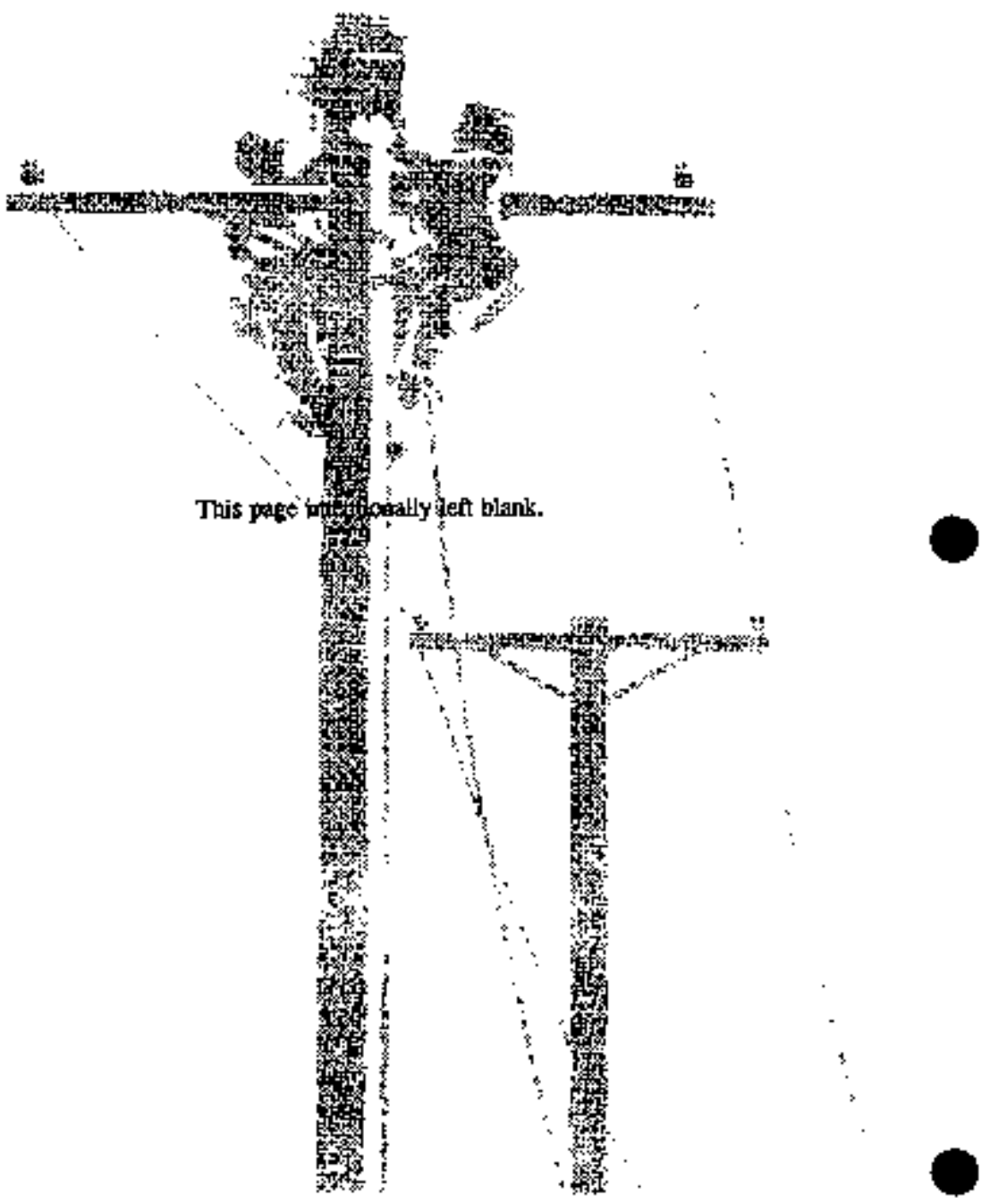




\section{APPENDEX C \\ ACTTVITY DESCRIPTIONS, START AND FINISH DATES FROM PROEECT HANFORD STUMMARY SCHEDULE \\ (Wonking Draft as of February 199T)}

TANKK WASTE REMEDLATION SYSTEMS "TAKX XASTE M-41-00 Issue Tank Characterizalion Reports Charecteriat Waste (all 177 tonks initial char)

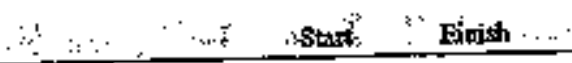
THAK SA M-40-00 Milipate/Resolve Tork Safery Issues High Priority Watch Ligt Tanks

Mitigale/Reolve Tank Safery lowes

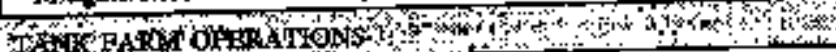

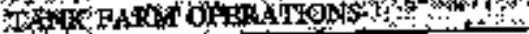

M-41-00 Complese Single Shed! Tomk Interial Stabilization.

$10-01-9609-28-01$

Interim \$labilize SST Fanmisurveillence \& Matal

Depploy Cross-Site Transfer System

Continue SurveinascedMaint of SST3

M-43-00 Complete Tank Fartit Upgrades

Tank Farm Uprrades 09-30.99

Recgive \& Transfer WastesiOper DST Farms

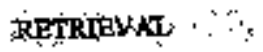

106-C Sludge Removal

106-C Hecl Remorval/Cketrout (HT)

106-C. Heel Rerooval Tech/Deploy Systems (HTI)

SST Clogere Dema (164-AX) (HIT) and

$09-2 B-0]$ nstint! 09-29.00 $10-01-96 \quad 09-29-00$ 1001-96 02-27-96 10-02-00 09-30-11 06-30-05 $10.01-96 \quad 06-30.05$ 10-01-96 09-30-11 "Stakt" " "Finglst" :" 10-01-96 12-31-97 07.01-99 09-29.00 $10-01.96 \quad 07 \cdot 01-99$ 10-01-96 09-29-100 
M-45-00 Complete Chosare of All Stngle Shell Tank Farms

09-30-24

SST Farm closures

$10-01-13$

(2)-30-24

Post Clogunes Monitoring 10-01-24 Comtinue

DST Farm Cosure 10-01.18 09-29-34

Depłoy lnitial SsT Retrieval Sytter (4 tan') $10-01-96 \quad 12-31-03$

Verify Rer Sys (4 innks) \& Retreve \$STT Waste (30 taniks)

$01-02-04 \quad 09-30-11$

Deploy/Operate Initipl DST Retrieval \$yskem

10-01-96 99-30-11

Demongteate DST Retrieval Perf W-151 $10-01-96 \quad 03-31.97$

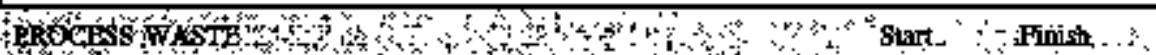
Retrieve remmining SST Waste (113 tanks) $10-03-11 \quad 09-28-18$

M-50-00 Coplp Predcatment PJocessing of Hanford Tank Waste 12-3I-28

Retriewe DST Waste for Processing $10-03-11 \quad 09-29-28$

Deploy Low Level Waste Inimobilization Phant(s) Phase 2 10-01-04 09-30-11

M-60-00 Comp Vtriffication of Hanford Low Level Tank Warte 12-31-24

LW Imrnobilization 10-03-11 12-31-24

LW Immobilization Facility Disposition 01-02-25 10-01-29

Deploy HLW Jmurobilixation Plant(s) Phase 2 $1001-04$

$00-30-13$

M-51-00 Complete Vitrifieation of Fanford HL Tank Waste 12-29-28

HLW Immobilization 10-01-13 09-29.2B

HLW Immobilization Facility Dispostition 10-02-28 $\quad 09-30-33$

LLW/HLW PretrestmenUIImmobtilization Phats 1 $06-03 \cdot 02 \quad 05-31-07$

Deploy LLW/ALW Irmobilization Phase 1 Plants 10-01-96 05-31-02

Continve Operations (optbonal)

06-01-07 05-31-I1

Facility Disposition 06-11-11 05-30-14

MOMOEMIZED TANK WASTE SMORAGE \& DISTOSAI.

Prepare Facilities for LLW Storage \& Disposeal

Stant Finish

LI,W Storage \& Disposal Operrations [0-0]-96 09-30-20

Chose LLW Slorage \& Disposal Facilities $10-01-02 \quad 12-31-24$

Post Ckanure Motiloring $05-02-05 \quad 09-30-27$

Deploy HLW Phase I Interim Storage Facllity (Mod vo CSB) 01-02.25 Continue $10-01-96 \quad 09-30-02$ 
Inapky HIW Phase 2 Interin Slorage Facility Modules

$10.01-08 \quad 09.30-24$

Freility Digposition

$10-01-42 \quad 02-30-43$

Deterimine CstSr Capsule Disposition

$10 \cdot 01-96 \quad 09-30-45$

(currently assimes owerpert \& strite)

Ship HLW to Repository

10-01-35 09-30-39

WASTE MANAGEMENT

¿ M-1900 Conplete Treatnert and/or disposition of LEMW Specifed Volumies

Direct disposal of LIMW

10-01-97 03-30-01

Waste Storage/Disposition Operations

10-01-96 contruved

Thermal Treatument of Wastes

01-02-01 09-30-16

M-JP-O Contplese WRAP I Conguction/lnitipte Operations

03-31-97

WRAP 1 Statup

$10-01-96$ 03-31-97

WRAP 1 Operations

04-01-97 09-30-31

Deploy Fhase 1 TRU Retritual system:

$06-01-99 \quad 09-28-01$

Phase 1 Relrieugl

10.01-01 09-30-04

Depioy Caisson Retrieval \$yateno

$10-01-02 \quad 09-30-05$

Caisson Retrieusl

10.03-05 09-30-09

Deploy Phast 2 ketrieval Sygutem

10-01-99 09-30-03

Phase 2 Retrierel

$10-03-06$

09-30-16

Ship Waste to Waste lsokation Pilot Project (WIPP)

10.01-98

09-30-31

M-32-00 Interim Status Dangzigous Wabue Tank System Fanford

09-30-31 Federal

Leak Detection Upgrades

$10-01-96$ 09-30-99

T-Plant Decontamination Stervice/RH-TRU Process

$10-01-96$ 09-30-18

Cantster Storige Bude Complex Operations

10-01-01 09-30-39 


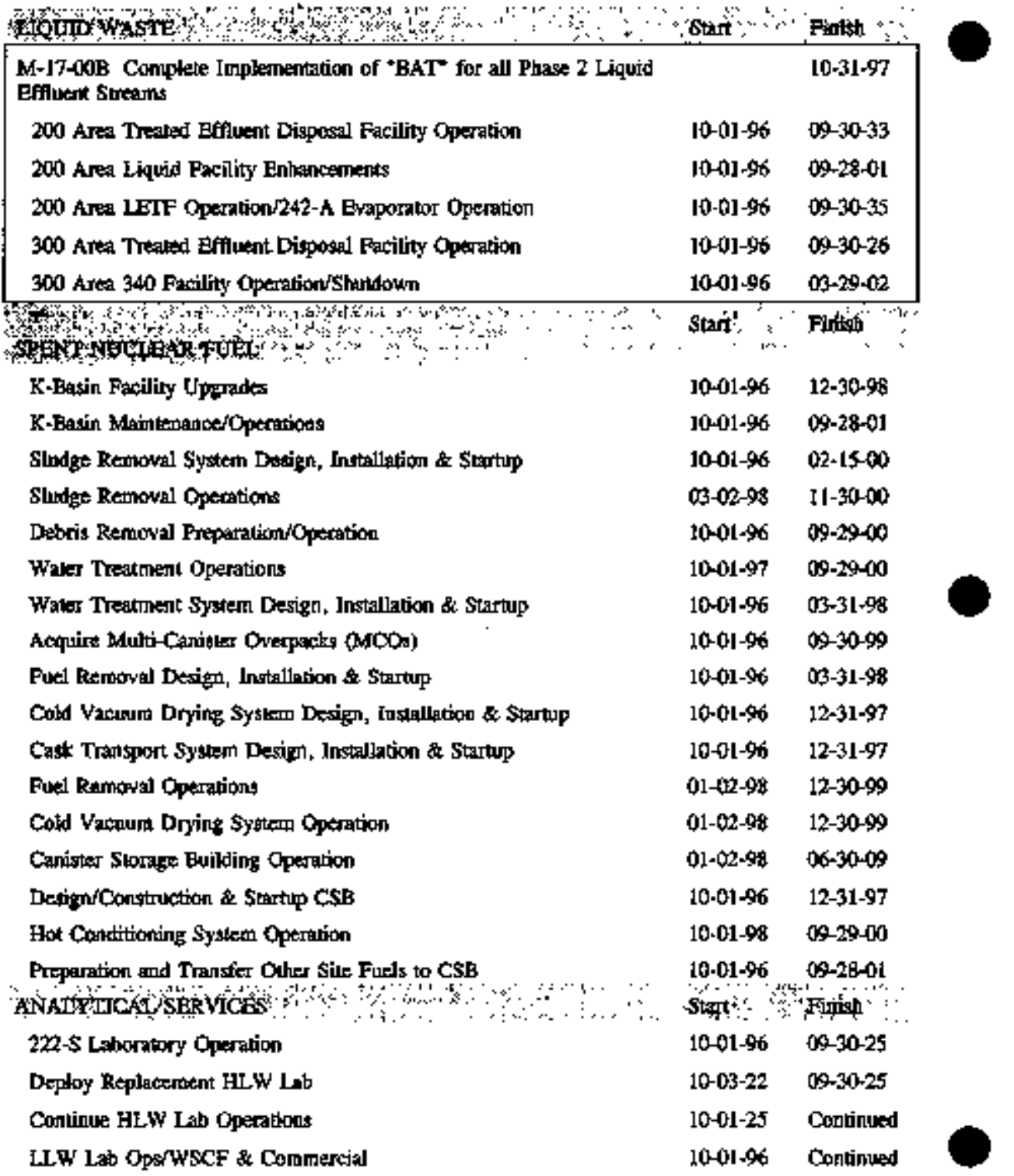




\section{FACIITTY TRANSTITHON}

Porkix

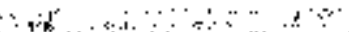

, +

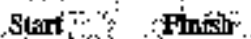

M-80-00 Complete PUREX(J)O3 Facility Trantition Phase a Initiane SeM

Compjete PUREX trousition

$10-01-96$ 0)-31-97

Cond

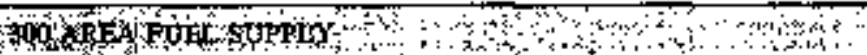

Complete 300 Area FSS Transition - Phase 2 Facilitics

Camplete 300 Arza FSS Transition - Phase 3

Slore and Ship Special Nuclear Materials (SNM)

Continue SNM Storhge Outside 3 OO Area Pres

Complete Thermal Stabilization

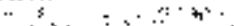

Coraplete Misc Material Disposition

Compite Folycabe Stabilization

Complete Solution Stabilization

07-31-98

$1001-96-013$

stân

$10-01-96 \quad 00-30-97$

10-01-96 09-30-98

10.01-96 $09-30-98$

$10-01-98 \quad 09-30-05$

Stiset . F Fististr

$10.01-96 \quad 05-03-02$

$10-01-96 \quad 05-31-02$

$10-01-96 \quad 09-30-99$

10-01-96. 06-24-98

M-83- $₫ 2$ Complete Identified Interim Actions (234-Z Draturork

Cleanout)

Complate Ductwork Cleanout

10-0I-96 I2-3I-988

PFP Facilities Cleanup and Transition

$10-01-96$

09-26.05

\$NM Vault \$trorace

10-01-96

Contimuad

B.PANF

Start . Finisti

B Plant Caryon Ventilation Upyade

$10-01-96 \quad 0909-98$

Decouple B Plant From WESP

1001.96

06- 30.98

M-82-00 Coroplete B Plant Trassition

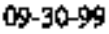

B Plant Transition

10.01-96

09-30-9B

WESF

Start

Einisisi

WESF Cleanlip and Upgrades

10-01-96

09-30-98

Rewm Remaining Capstales to WESF

$10-01-96$

$0.50-30-98$

Cust Capsule Storage

10-01-96

10-00-11

Dispostitkn Capsules

10-02-08

10-03-11

WESP Transition

$10-04-11 \quad 10-02-13$ 


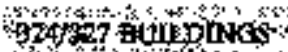

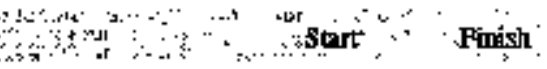

Transition 324/327 Facnlities

$10-01-99 \quad 09-30-02$

324/327 Surveilance, Maintenance and Operations

$10-01-96 \quad 00-30-99$

M-69-02 Complette Remorkal of 324 Buds and Remose B-Cell MW and equipment

B-Cell Cleanout $10-01-96 \quad 08-20-99$

W.

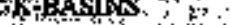

K-Basins Trensition

Start

Finisth

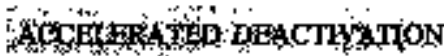

10-01-0] 10-01-05

Complete Remaining Desctivation Stpit: :

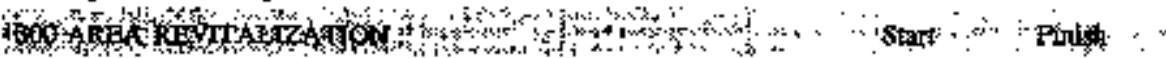

$10-01-98 \quad 09-30-38$

Revilatle for use/deactivate 300 Area facilities 10-01-99 Coutinued

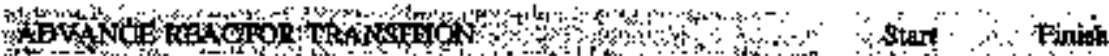

Fad OfloadfIRM Cell Clospre $10-01-96 \quad 04-24-00$

Desctivale Auxiliary System

$10-01-96 \quad 01-04-00$

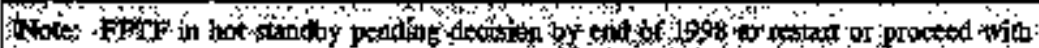
Aeptivatióni.

M-81-00 Complete FFTF Trusition and lnitiate SolM Phase $12-31501$

Complete FFTF Transition $01-05-00 \quad 03-30-01$

Sodium Skrage Facility Stanup $10-0196$ 01.31.97

Drain Sodtum $02-03-97 \quad 02-28-00$

Sotium Storase

02-03-97 02-28-00

Sodingm Reaction

a3-31-01

$03-31-03$

Sodlum Reactlon facllity Destgn a Consuruction

10-01-98

03-3]-01

Complete 309 Facilities Trantition

10-01-96

09.30-98 


\section{GNVLRONMENTAL RESTORATTON}

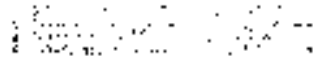

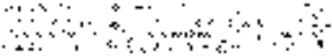

Startis:" “Finisti".

N Rector Deactivation

$10.01-96 \quad 09-39-97$

Reactos Dispostitioning

$10-01-24 \quad 09-29-34$

Facility Survillance and MoiruDispostitioning

10-01-96 Continued

100 Area Ancillaries Dispositioning/Reactor Interim Safe

(1)-01-96 09-29-17

Storage

200 Area Ancillarists Dispositioning

10-03-16 09-30-24

Groundwater Remediation

$10-01.96 \quad 09-30-10$

M-16-Do Complete Remedial Actions for all non Tank Farro Operable $09-28-18$ Units

M-15-90 Complete the Rl/FS (or RFI/CMS) for all Operable Units 12-31-08

M-13-00Q Sutmit 4 200 NPL RLPS (RFFTCMS) work Plans 12-29-06

Waste Sile Remediation/ERDF Operdions

$10-0106 \quad 09-29-34$

SCIENCE AND TECHNOLOGX

\section{$\because$ SCO}

Wh and Operational Compliance

Start .. Findsh

10-01-96 Continued 


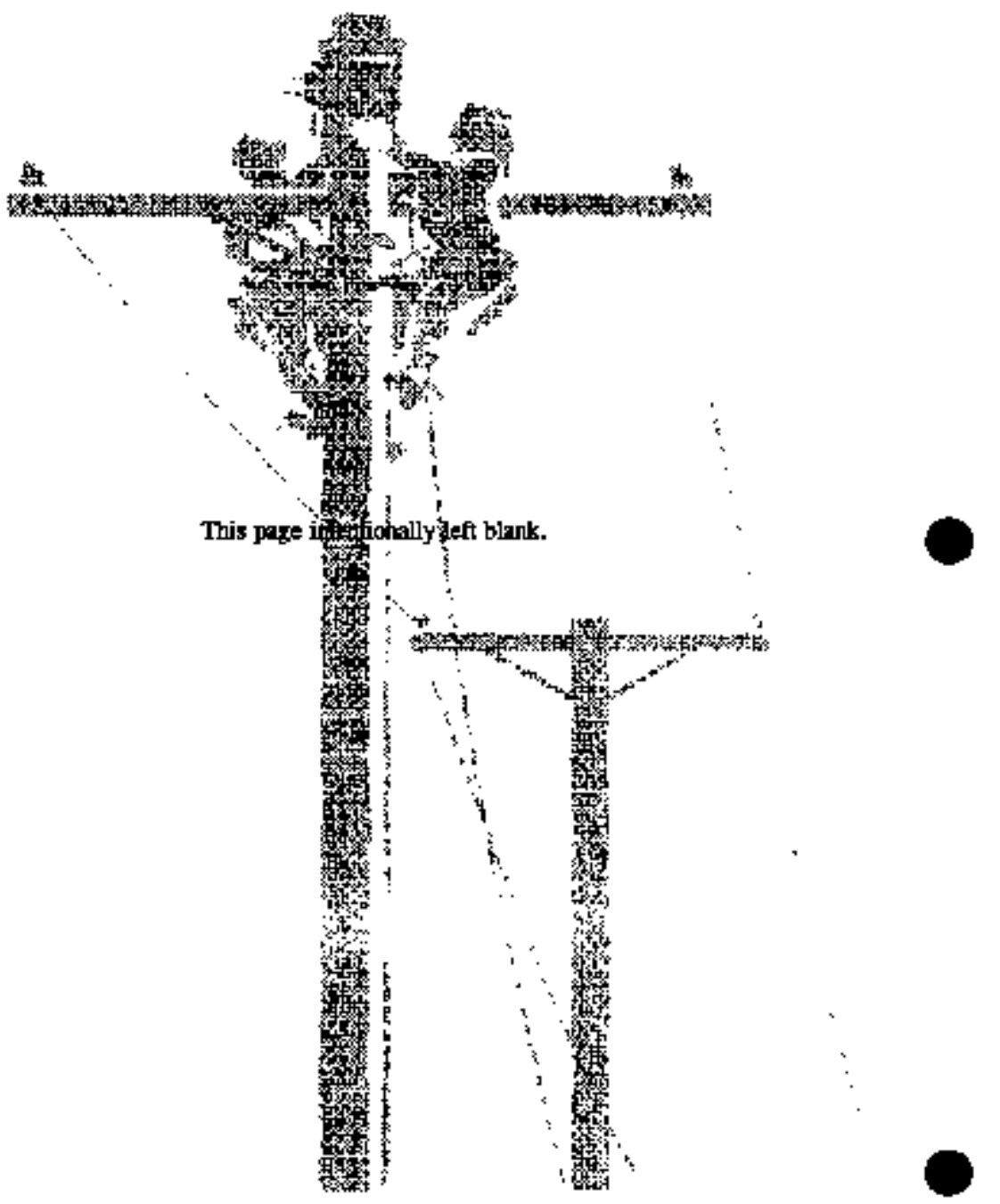




\section{NWW-SP-18A8}

\section{DSTRIBUTLW}

\section{A:Inter of contis}

\section{ONSTIE}

\section{IIs}

Bienlent Ooderetous Oor

S. T. Butrum

12.45

W. A. Ruhbnati

R3-79

W. A. Rutherford (B)

22.45

W. A. Whis

1245

DOE Pubis Foading Room

H2.53

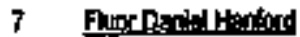

\begin{tabular}{|c|}
\hline 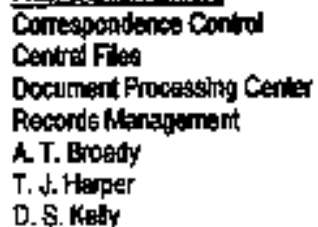 \\
\hline
\end{tabular}

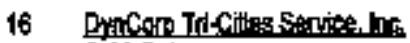
S. HA Bakr
J. W. Bodey
S.L Gamp
s.-12
L1-18
J. L. Dey
나구
L. L. Deibrinoy
S2-6i
63-07
R.Desirione, Jr. (2)
10,16
F. L. Fittz
S2-12
R. S. Fix
$\mathrm{H}-3 \mathrm{-3}$
R. R. Grontham
S2-23
J. Wh. Hech
S2-12
P. C. llet:
S:-21
K. J.Nem
Lo-16
S.D. Protsm
Q3, 05
G. A. Schnedibek
Q3-05
P. L. Tajlax
\$2-12

더여 - 1 
HNF-SP-1236, REV. O

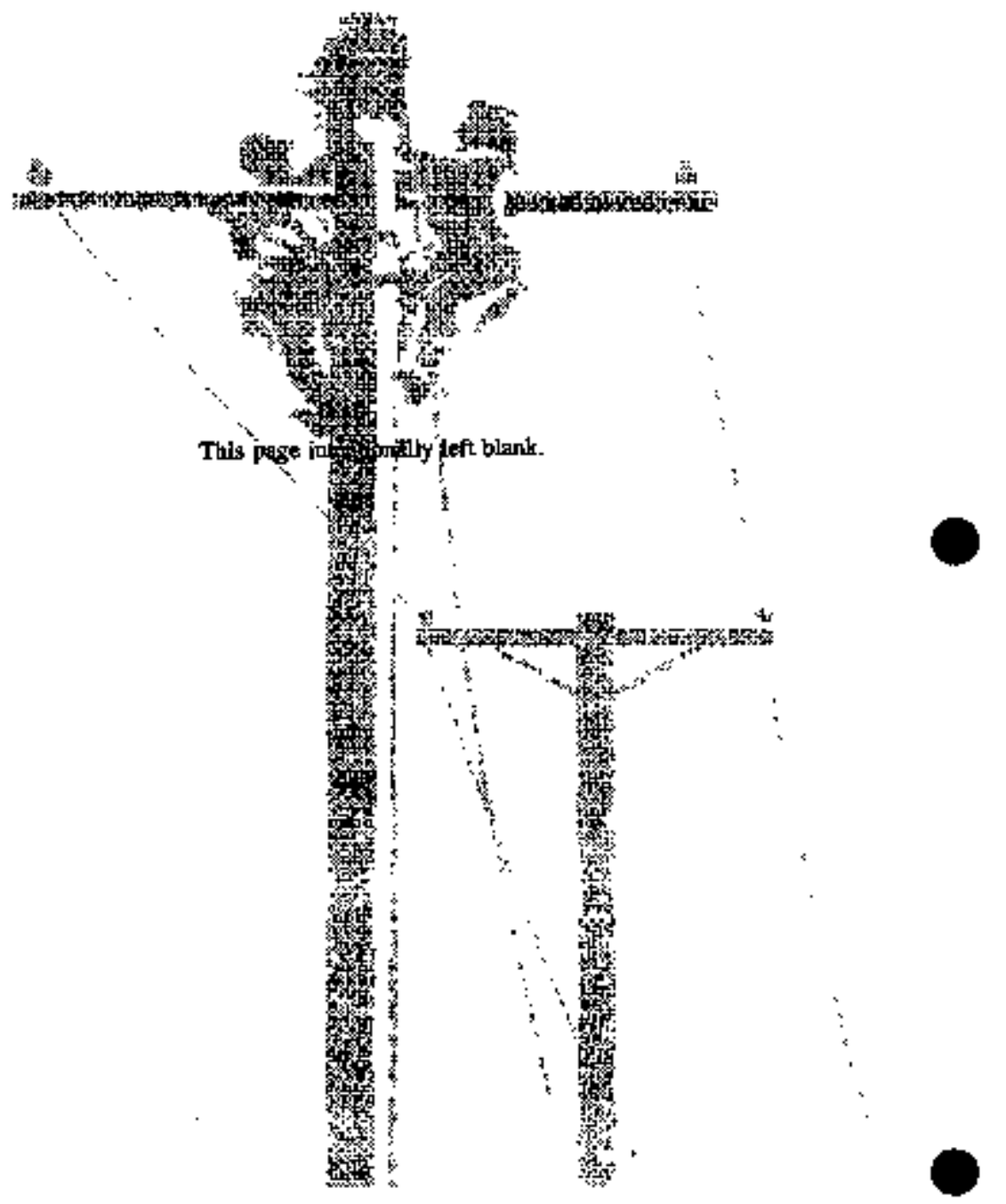

